$$
\begin{gathered}
\text { José Miguel Verónica } \\
\text { Tuñez Paulina } \\
\text { López Altamirano } \\
\text { coordinadores } \\
\text { Prólogo: María Yolanda Martínez Solana } \\
\text { Comunicar desde las } \\
\text { organizaciones } \\
\text { Tendencias, estrategias y casos }
\end{gathered}
$$

\section{Comunicar desde las organizaciones \\ Tendencias, estrategias y casos}

Cuadernos Artesanos de Comunicación / 96
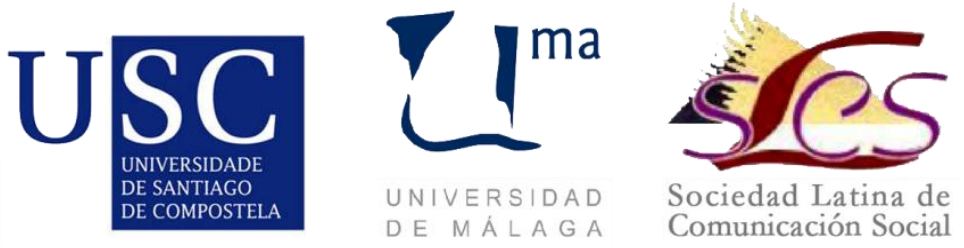


\section{Cuadernos Artesanos de Comunicación}

Coordinador editorial: José Manuel de Pablos

Comité Científico

Presidencia: José Luis Piñuel Raigada (UCM)

Secretaría: Concha Mateos (URJC)

- Paulina B. Emanuelli (Universidad Nacional de Córdoba, UNC)

- José Luis González Esteban (Univ. Miguel Hernández de Elche)

- Marisa Humanes (Universidad Rey Juan Carlos, URJC)

- Juan José Igartua (Universidad de Salamanca, USAL)

- Xosé López (Universidad de Santiago de Compostela)

- Maricela López-Ornelas (Universidad Autónoma de Baja California)

- Javier Marzal (Universidad Jaume I, UJI)

- José Antonio Meyer (Benemérita Universidad Autónoma de Puebla)

- Ramón Reig (Universidad de Sevilla, US)

- Miquel Rodrigo Alsina (Universidad Pompeu Fabra, UPF)

- Xosé Soengas (Universidad de Santiago de Compostela)

- José Luis Terrón (Universidad Autónoma de Barcelona, UAB)

- Victoria Tur (Universidad de Alicante, UA)

- Miguel Vicente (Universidad de Valladolid, UVA)

- Ramón Zallo (Universidad del País Vasco, UPV-EHU)

- Núria Almiron (Universidad Pompeu Fabra, UPF)

- Francisco Campos Freire (Universidad de Santiago de Compostela)

- José Cisneros (Benemérita Universidad Autónoma de Puebla)

- Bernardo Díaz Nosty (Universidad de Málaga, UMA)

- Carlos Elías (Universidad Carlos III de Madrid, UC3M)

* Queda expresamente autorizada la reproducción total o parcial de los textos publicados en este libro, en cualquier formato o soporte imaginables, salvo por explícita voluntad en contra del autor o autora o en caso de ediciones con ánimo de lucro. Las publicaciones donde se incluyan textos de esta publicación serán ediciones no comerciales y han de estar igualmente acogidas a Creative Commons. Harán constar esta licencia y el carácter no venal de la publicación.

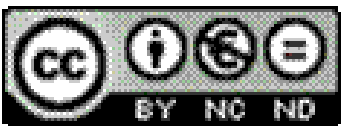

Este libro y cada uno de los capítulos que contiene (en su caso), así como las imágenes incluidas, si no se indica lo contrario, se encuentran bajo una Licencia Creative Commons Atribución-No Comercial-Sin Derivadas 3.0 Unported. Puede ver una copia de esta licencia en http://creativecommons.org/licenses/by-nc-nd/3.0/ Esto significa que Ud. es libre de reproducir y distribuir esta obra, siempre que cite la autoría, que no se use con fines comerciales o lucrativos y que no haga ninguna obra derivada. Si quiere hacer alguna de las cosas que aparecen como no permitidas, contacte con los coordinadores del libro o con el autor del capítulo correspondiente. ${ }^{*} \mathrm{La}$ responsabilidad de cada texto es de su coordinador-autor 
José Miguel

Túñez López
Verónica Paulina

Altamirano Benítez

Coordinadores

Prólogo: María Yolanda Martínez Solana

\section{Comunicar desde las organizaciones \\ Tendencias, estrategias y casos}

Cuadernos Artesanos de Comunicación / 96

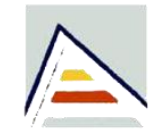

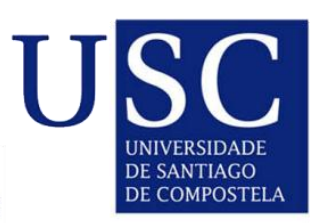
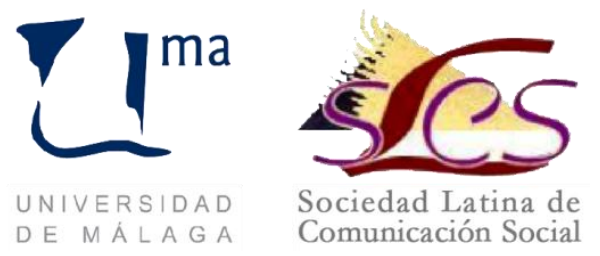
$96^{\circ}$ - Comunicar desde las organizaciones: Tendencias, estrategias y casos

José Miguel Túñez López y Verónica Altamirano |

Precio social: 8,20€ | Precio en librería. 10,65€ |

Editores: Javier Herrero y Alberto Ardèvol Abreu

Diseño: F. Drago

Ilustración de portada: Fragmento del cuadro Mujer con bernegal, de Pedro de Guezala (1958).

Imprime y distribuye: F. Drago. Andocopias S. L.

c/ La Hornera, 41. La Laguna. Tenerife.

Teléfono: 922250554 | fotocopiasdrago@,telefonica.net

Edita: Sociedad Latina de Comunicación Social - edición no venal

- La Laguna (Tenerife), 2015 - Creative Commons

http://www.revistalatinacs.org/14SLCS/portada2014.html

Descargar en pdf:

http://www.cuadernosartesanos.org/\#96

Protocolo de envío de manuscritos

http://www.cuadernosartesanos.org/protocolo.html

ISBN - 13: 978-84-16458-27-1

DL: TF-905-2015

DOI: $\underline{10.4185 / \operatorname{cac} 96}$ 


\section{Índice}

Prólogo

María Yolanda Martínez Solana .............................................................. 7

Capítulo 1: Comunicación Interna................................................... 13

El uso de vídeos compartidos en la construcción de la reputación corporativa

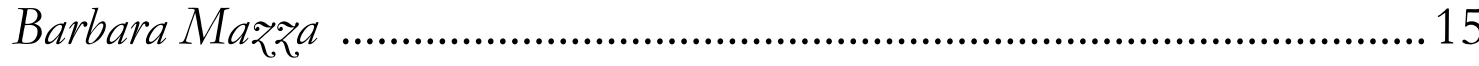

Capítulo 2: Comunicación Externa .................................................. 41

De los atrezzos comunicativos

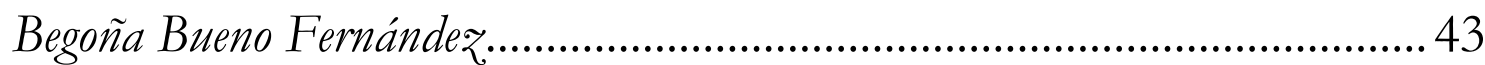

Las narcomantas: vía para producir noticias en un clima de violencia Melitón Guevara Castillo.

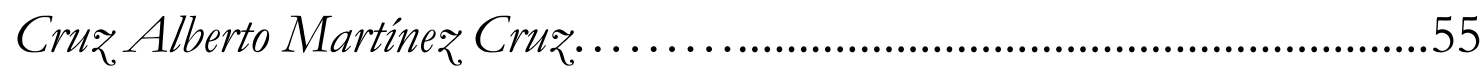

El color, la forma: su influencia en el empaquetado y en la imagen corporativa

Juan Luis Gamarra Sánchez.

Marta González-Peláez.

La comunicación y el entorno del público externo en las

organizaciones sanitarias

Ana María Mañá Álvarez.

Del Dircom al Marcom, un proceso de evolución de la comunicación Cesibel V aldiviezo y Karina V alarezo.

Capítulo 3: Comunicación Digital

Gestión de herramientas 2.0: El caso de la Casa Real

$M^{a}$ Dolores García Fernández.

La comunicación lúdica: nuevos mecanismos de atracción

Enrique Morales Corral.........................................125

Responsabilidad Social Corporativa y medio ambiente en YouTube Carmen Costa ................................................143

Herramientas y recursos que mejoran la experiencia del turista

Verónica Altamirano

Miguel Túnez.

Coordinadores y autores 


\title{
Comunicar desde las organizaciones Tendencias, estrategias y casos
}

[noviembre de 2015]

\begin{abstract}
Las organizaciones tienen la necesidad imperante de gestionar las relaciones con sus principales stakeholders. La comunicación estratégica e integral es fundamental en ese proceso porque se ha convertido en una herramienta que contribuye a la consecución de los objetivos organizacionales y la creación y/o mantenimiento de la imagen y la reputación de la entidad.
\end{abstract}

Nuestro interés en el presente Cuaderno es ver los grandes planes fijándonos en el detalle. Por eso, la propuesta parte de analizar pequeñas aspectos de las estrategias comunicacionales que, sin embargo, suponen aportas significativamente al cumplimiento de los objetivos de las estrategias de comunicación.

Los autores que han elaborado los textos de esta obra se han fijado en analizar actuaciones concretas y en revisar casos exitosos de comunicación interna, externa o digital para ir definiendo las tendencias que van marcando los cambios en la actualidad. Por eso, en sus análisis se incluyen herramientas novedosas y de vanguardia, pero, también herramientas tradicionales que se modernizan y se adaptan a las nuevas exigencias del mercado.

Keywords: Comunicación organizacional, herramientas de comunicación, estrategias de comunicación, Nuevas Tecnologías de la Información y de las Comunicación, comunicación interna, comunicación externa, comunicación digital.

\section{Forma de citar este libro}

Autor/ra del capítulo (2015): "Título del capítulo" en Comunicar desde las organizaciones: Tendencias, estrategias y casos (Miguel Túñez López y Verónica Altamirano, Coord.). Cuadernos Artesanos de Comunicación, 96. La Laguna (Tenerife): Latina. 


\section{Prólogo}

\section{La gestión de la comunicación en las organizaciones del siglo XXI}

T A noticia si no se publica, no será noticia. Esta afirmación puede 1 parecer un juego de palabras pero no es tal. Cuando empezábamos a acercarnos a los estudios universitarios sobre Periodismo, en los años 80, mirábamos con cierta sorpresa a quienes repetían esa especie de mantra; encontrábamos que era una obviedad, sin percatarnos que escondía un meta mensaje: la situación mas dramáticamente, políticamente, judicialmente... más relevante pasaba desapercibida si no encontraba un medio en el que publicarse. Por lo tanto la visibilidad era lo que convertía el suceso noticioso en una noticia real.

Han pasado varias décadas y es hora de que apliquemos ese método reiterativo y eficaz de repetir un concepto real, hasta que sea comúnmente reconocido y aplicado. "Si cree en la institución apueste por la comunicación", este podría ser mensaje principal de lo que debe considerarse el principio a seguir para lograr que la comunicación fluya de forma óptima entre la fuente informativa implicada en dar a conocer lo que hace y el receptor múltiple que es la sociedad en el Siglo XXI. Las organizaciones, instituciones... han dejado de poder administrar la información de la que disponen en 
virtud de sus intereses. Ya no existen esas zonas de sombra o penumbra informativa que quedaban fuera del canal comunicativo.

La transparencia no es ya un credo de quienes consideramos que ética profesional nos obliga a actuar de una determinada forma, aunque alguien sea "apostata" de la obligación de informar a los ciudadanos, la aparición de las nuevas tecnologías de la información ha roto el monopolio de la información. Es impensable trabajar en un modelo de Comunicación que dé la espalda a las TICs, ha de lograrse una óptima utilización de las redes internas y externas, dotándolas de contenidos y homologando portales que secunden los objetivos de comunicación y, en su caso, divulgación de la institución.

Ninguna organización puede mantenerse exenta de aplicar una política de comunicación eficaz que permita conocer la dimensión real de lo que se hace o se va a hacer. Es imprescindible realizar una labor de elaboración e implantación de un plan de comunicación "a medida" en cualquier institución u organización con dimensión social, porque se quiera o no siempre se está emitiendo un mensaje, aun cuando no se diga nada. En el Siglo XXI la demanda de información cualificada sobre asuntos estratégicos nos sitúa ante un reto imposible de eludir: proporcionar eficazmente la comunicación que nos requieren. Existe el riesgo de confundir proporcionar mucha información con información de calidad. Una sociedad como la actual nunca había dispuesto de tantos medios de comunicación y de una información tan abundante en contenidos y procedencia, y con tanta rapidez en su recepción.

Donde quienes gestionan la Comunicación de las organizaciones realmente se juegan su prestigio es en la Ética, ella es la base de la credibilidad. El hermetismo informativo es tan inadecuado como una aparente transparencia informativa que solo trata de ocultar la realidad con una gruesa capa de maquillaje. De nuevo la ética, si se aplica, protege al responsable de Comunicación de salvar su credibilidad y no hipotecar su futuro. La ética en comunicación se podría resumir en una sola frase "decir lo que se hace y hacer lo que se dice". Se hace pues necesario que la honradez sea la pieza clave en la identidad de las fuentes informativas: La ética es la base de la 
credibilidad y la credibilidad es el valor más apreciado por un periodista al tratar con sus fuentes habituales de información.

Gestionar la Comunicación en el Siglo XXI pasa por diseñar planes eficientes (y por lo tanto adecuados) a las organizaciones. Ello otorgara la máxima coherencia a la política de comunicación global de la institución, de modo que responda a unos objetivos y estrategias comunes para todas las instancias de la organización. Asimismo, es conveniente impulsar la comunicación interna, a fin de asegurar las acciones necesarias para que la información (institucional y operativa) fluya de manera regular y constante en el seno de la entidad y llegue sin distorsiones a sus destinatarios naturales (los distintos estamentos de la institución).

Este Cuaderno de Comunicación nos permite "tomar el pulso" a la Comunicación que se realiza en la actualidad, e incluso nos proporciona líneas emergentes de lo que será próximamente. Bárbara Mazza apunta a la importancia de los empleados en la construcción de la imagen y reputación empresarial. Se aportan los resultados de un análisis realizado sobre los casos de excelencia que aprovechan de estas modalidades de comunicación. Sobre los atrezzos comunicativos, Begoña Bueno Fernández establece la dimensión real del papel que desarrollan el protocolo y el ceremonial en las empresas públicas y privadas. Destaca que el protocolo en la actualidad se concibe como un valor más dentro de la política de comunicación de la empresa que complementa la labor del marketing, potencia la publicidad, alimenta el gabinete de comunicación y estimula las relaciones públicas, puede incluso considerarse una forma de comunicación persuasiva que ayudará a conseguir una imagen positiva de nuestra organización. la organización de un acto o evento empresarial que nos ayudará a transmitir una imagen institucional determinada. Un correcto o incorrecto uso de las normas que rige un evento puede suponer que nuestro acto sea un éxito o todo un fracaso, con las consecuencias de imagen corporativa que esto supone.

El Dr. Melitón Guevara Castillo y el Dr. Cruz Alberto Martínez Cruz nos describen en "Las narcomantas: vía para producir noticias en un clima de violencia", una nueva forma de expresión en este caso para 
las organizaciones de narcotraficantes en México. Tamaulipas no es la excepción en donde dos grupos de la delincuencia organizada se disputan el control del "territorio". Destacan que el gobierno del estado sigue la política de silenciar los hechos. Las narcomantas, de uno y otro bando, son colocadas en lugares estratégicos, difundidas en las redes sociales y publicadas en los medios de comunicación, conformándose como una nueva vía de emisión de mensajes.

Marta González-Peláez y Juan Luis Gamarra Sánchez, han analizado la influencia del color y la forma en la imagen corporativa que proyecta una organización. Baste decir que el ochenta y cinco por ciento del público objetivo y del potencial cliente a la hora de la decisión de compra observa el color como el elemento determinante de la culminación de la adquisición. La extrapolación de esta realidad a la comunicación organizacional nos da una visión real del papel que pueden jugar estos elementos en la percepción social de la misma.

La Comunicación es de capital importancia en cualquier ámbito social, pero en el campo de la sanidad aún lo es más. Ana María Mañá Álvarez destaca que las organizaciones sanitarias, entendidas como empresas de servicios, orientan su política de comunicación externa al usuario activo (paciente hospitalizado, en consulta externa,...) dado que una adecuada gestión de la comunicación en el entorno del usuario permite mejorar tanto su propia satisfacción, como la imagen que proyecta la organización sanitaria.

Las herramientas para el turista 2.0, experiencias que marcan la diferencia en los destinos turísticos, resalta que la comunicación turística adquiere relevancia en el entorno mundial gracias a la creciente importancia del turismo como generador de desarrollo y alternativa de crecimiento económico en diversos países. Por lo tanto tal y como resaltan sus autores, Máster Verónica Altamirano y Dr. Miguel Túñez López, debe adaptarse a la constante evolución de las nuevas tecnologías de la información y de la comunicación. las aplicaciones para dispositivos móviles y recursos para descargar que aportan al turista facilidades para el viaje y permiten mejorar la experiencia durante la visita, cumpliendo con las exigencias del turista 2.0 
La Dra. Ma Dolores García Fernández aborda la utilización de herramientas 2.0 como elemento vertebrador de la Comunicación Institucional. Estudio del Caso: La Casa de SM el Rey y destaca que la utilización de estas herramientas modifican a su vez las rutinas comunicacionales del equipo de comunicación de la Casa de SM el Rey, que también han renovado sus sistemas de trabajo. La Casa Real en aras de adaptarse a estos cambios, ha incluido algunas novedades en su comunicación institucional para tratar de conseguir el entendimiento con sus públicos. "La comunicación lúdica: nuevos mecanismos de atracción" del Dr. Enrique Morales Corral, destaca el fenómeno de gamification o gamificación, que ya está cambiando algunas de las reglas de juego de procesos organizacionales. Se hace hincapié en su influencia como mecanismo integrador y socializador de estructuras que durante mucho tiempo han permanecido rígidas, empezando a superar todas las expectativas que sobre ella se tenían.

El paso del Dircom al Marcom, o lo que es lo mismo un concepto integral de lo que es la labor del Director de Comunicación ampliando sus competencias, pone el dedo en la llaga de la necesaria evolución hacia nuevos ámbitos de actuación. Si el Dircom coordina procesos de comunicación a nivel interno y externo, para facilitar el trabajo entre la institución y los públicos objetivos, el denominado Marcom, que es la fusión de la comunicación institucional, el marketing y la publicidad, se abre paso donde se persiguiendo un trabajo de manera integral y bajo un mismo paraguas comunicacional de todas la áreas.

María Yolanda Martínez Solana Directora de Comunicación / Vicerrectora Universidad Complutense de Madrid 



\section{it \\ Comunicación Interna}





\section{El uso de vídeos compartidos en la construcción de la reputación corporativa}

Barbara Mazza

Università degli studi di Roma, La Sapienza

\section{Resumen}

En la actual economía globalizada, los mecanismos de la competitividad entre las empresas, con el fin de adquirir visibilidad y dominio en los mercados, son muy acentuados. En este escenario el empleado es cada vez más el foco de la lógica de gestión, e incluso, está directamente implicado en la vida empresarial, en su funcionamiento, en sus perspectivas de innovación para el progreso, así como en la construcción de la imagen y reputación.

Los trabajadores se convierten en los protagonistas de la representación empresarial y en ellos se delinean historias, mezclan mitos y símbolos de la organización con el fin de hacerlos más comprensibles y más cercanos a los usuarios externos. Para comprender la eficacia de la comunicación empresarial, se decidió centrar el análisis en algunas de las mejores prácticas en la construcción de relatos empresariales a través de vídeos compartidos. Por lo tanto se han elegido las empresas reconocidas como las mejores en la clasificación mundial 25 Best World Companies.

Palabras clave: comunicación, imagen, reputación, trabajo, videos compartidos, "cazador de cabezas 


\section{Introducción}

F $\mathrm{N}$ la actual economía globalizada, los mecanismos de competitividad entre las empresas, con el fin de
visibilidad y dominio en los mercados, son muy acentuados.

Hay muchos factores que contribuyen, pero se indicaran los tres principales: el primero está determinado por la tendencia fluctuante de la economía internacional, que tiende a redefinir constantemente los límites geográficos de expansión y contracción de la oferta y la demanda (Valdani, Bertoli, 2010); el segundo, es la intensificación de los flujos de comunicación, que requieren una mayor atención a las necesidades del cliente final, ahora "desintermediado" (Bolter, Grusin, 2003) y cada vez más activo y protagonista de los procesos empresariales. No menos importante, la tercera dimensión debe tener en cuenta los complejos cambios en las organizaciones que, en los últimos veinte años, han transformado radicalmente los procesos de gestión de recursos humanos y las relaciones entre el "ecosistema empresarial" (Genco 2014, Lamborghini 2009).

En virtud de la consolidación del paradigma de la comunicación integrada y estratégica (Invernizzi, Romenti, 2011; Johansson, Ottestig, 2011; Toschi 2011), sobretodo en medianas y grandes empresas, la concepción generalizada ve la empresa como un organismo cuyo funcionamiento está garantizado por la participación de todos los recursos internos y externos: desde los empleados, colaboradores, "stakeholders", hasta la gestión en los sectores institucionales y financieros, etc.

En este escenario, el empleado - con sus peculiaridades, niveles y calificaciones - ya no es un simple empleado encargado de cuidar y fomentar una visión instrumental vinculada a la productividad. El empleado es cada vez más el centro de la lógica de gestión, e incluso, está directamente implicado en la vida empresarial, en su funcionamiento, en sus perspectivas de innovación para el progreso, así como en la construcción de la imagen y reputación. 
Los trabajadores se convierten en los protagonistas de la representación empresarial y en ellos se delinean historias, mezclan mitos y símbolos de la organización con el fin de hacerlos más comprensibles y más cercanos a los usuarios externos, adaptándolos en función de los objetivos específicos propuestos. Precisamente por esta razón, la comunicación se encomienda a veces a los gerentes y directores de áreas, pero generalmente los testigos excelentes - o líderes de opinión (Katz, Lazarsfeld, 1955) - son los empleados que trabajan en las áreas estratégicas de la organización.

El uso del vídeo para transmitir los mensajes de los testigos internos está dictado por la conciencia de que la predilección por este instrumento se ha hecho omnipresente en el mundo de los negocios. Es bastante decir que, ya desde hace más de cinco años, el intercambio de vídeos se ha extendido más del $83 \%$ en las empresas de todo el mundo, y que es el principal medio de comunicación adoptado (McKinsey Encuesta, 2009). Junto a la plataforma más usada en el mundo, que es YouTube seguido por Vimeo, creció especialmente en las grandes organizaciones - la activación de la web TV empresarial, no solo para compartir contenidos entre los empleados, sino para mejorar las relaciones con las partes interesadas y los clientes finales, con el fin de dar a conocer servicios y productos y para fomentar formas de intercambio. Una encuesta sobre el uso de los social media, en el $2011^{1}$ pone de relieve cómo las empresas que han utilizado un canal de YouTube para comunicar crecieron un $39 \%$, alcanzando una penetración del $79 \%$ entre el listado de empresas internacionales "Fortune Global 100".

Estas cifras están confirmadas por otra investigación realizada por Social Media Examiner: un observatorio de Estados Unidos que, en el 2012, según un estudio hecho a nivel mundial sobre 3.800 empleados de mercadotecnia, afirma que el 76\% de la muestra tiene la intención de invertir en vídeos compartidos para la comunicación empresarial (Stelzner, Social Media Examiner Report, 2013).

\footnotetext{
${ }^{1}$ Ver: Burson-Marsteller, The Third Annual Global Social Media Check-Up 2012 (con respecto a la encuesta hecha en el 2011), http:/ / sites.bursonmarsteller.com/social/Summary.aspx
} 
También, la edición del año pasado (Stelzner, Social Media Examiner Report, 2014: 38), que se centró en 2.887 operadores, confirma la misma intención, por lo que un significativo $67 \%$ de los vendedores planean aumentar sus iniciativas de comunicación a través de YouTube, diferenciando la forma abreviada para fines comerciales de una más extendida para contar la identidad corporativa. Más de la mitad de los trabajadores (58\%) identifican la "originalidad del contenido" como el principal elemento que tiene que ser desarrollado junto a la atención por las formas expresivas y narrativas, especialmente cuando se dirige a los usuarios internos y las partes interesadas.

Para comprender mejor la eficacia de este instrumento, el análisis presentado en este documento se centra en empresas reconocidas como con "buenas prácticas", capaces de aprovechar de la producción de vídeos para difundir la imagen de ellas mismas como "el mejor lugar para trabajar." Se decidió, por lo tanto, en el listado de Fortune Global, que ahora tiene un reconocimiento en todo el mundo, identificar las grandes organizaciones internacionales que están en la cima de la clasificación mundial, con el fin de reconocer los mejores sitios para trabajar en los últimos tres años (Great Place to Work Institute, 2012-2014). Elegimos estas tipologías organizacionales porque sabemos que la credibilidad de este instrumento deriva directamente de la satisfacción de los empleados que trabajan allí y que sólo bajo estas condiciones, ellos pueden convertirse en líderes de opinión válidos y eficaces para su empresa (Cuomo, Tortora, Metal 2014).

\section{Metodología}

Para comprender la eficacia de la comunicación empresarial, con el fin de presentar lo más eficazmente posible los objetivos a los públicos estratégicos, se decidió centrar el análisis en algunas de las mejores prácticas en la construcción de relatos empresariales a través de vídeos compartidos. Por lo tanto, para llevar a cabo la encuesta, se han elegido las empresas juzgadas mejores en el ranking mundial (25 Best World Companies), de acuerdo con las conclusiones de la investigación llevada a cabo a través de entrevistas, que se hace 
anualmente por el Great Place to Work Institute en más de 10 millones de empleados de más de 45 países en seis continentes.

En concreto, se trata de sectores profesionales que operan a nivel mundial, reconocidos, en el período 2012 - 2014, como unos de los 25 mejores del mundo, gracias a la creación de condiciones de trabajo favorables para los empleados. La elección de los últimos tres años como plazo previsto permite seleccionar - entre los 36 posibles aquellas realidades empresariales más sólidas en la gestión interna y que, por lo tanto, permanecen en la cima de la clasificación con más continuidad.

Entre los principales parámetros adoptados por el Great Place to Work para el rastreo de las mejores compañías está el cuidado de las condiciones y ambiente de trabajo se incluyen: la gestión de los recursos humanos; la posibilidad de convertirse en líderes; los resultados obtenidos por el crecimiento profesional de los individuos; el intercambio de conocimientos; la difusión de la cultura organizacional; la confianza de los empleados en la empresa; el respeto de los principios fundamentales de la responsabilidad social de las empresas; el respeto a la diversidad y la inclusión de los individuos.

Los resultados, en forma de un listado de mejores empresas, son publicados por el Financial Times (Reino Unido), Fortune (EE.UU., Corea), Período (Brasil) y El Día (Nigeria) y constituyen, para las empresas, un importante reconocimiento, por lo que todos lo mencionan en su página web corporativa en el espacio dedicado a los "Premios", también como un instrumento de credibilidad y reputación, especialmente en el proceso de reclutamiento.

De las 36 organizaciones se decidió centrar la investigación sobre 21 empresas, es decir, aquellas que mantienen una estabilidad en la tabla de posiciones (10) e incluso las que están creciendo, porque con el tiempo han mejorado sus posiciones (5). Se consideró útil añadir también las organizaciones que, por primera vez, han logrado este reconocimiento (6) por el aumento en la atención al ambiente de 
trabajo; por el contrario, han sido excluidos los que perdieron posiciones (15).

La tabla 1 muestra las empresas multinacionales inscritas entre las mejores, en referencia al período de tres años:

Tabla1. - Las 36 World Best Companies en referencia al período 2012-2014

\begin{tabular}{|l|l|l|}
\hline GOOGLE & Autodesk & $\begin{array}{l}\text { THE COCA-COLA } \\
\text { COMPANY }\end{array}$ \\
\hline SAS INSTITUTE & TELEFÓNICA & Kimberly-Clark \\
\hline NETAPP & $\begin{array}{l}\text { NATIONAL } \\
\text { INSTRUMENTS }\end{array}$ & BBVA \\
\hline $\begin{array}{l}\text { W. L. Gore \& } \\
\text { Associates }\end{array}$ & $\begin{array}{l}\text { FEDEX EXPRESS } \\
\text { CORPORATION }\end{array}$ & Hilti \\
\hline BELCORP & ATENTO & Quintiles \\
\hline MICROSOFT & EMC & McDonald's \\
\hline MARRIOTT & $\begin{array}{l}\text { DAIMLER FINANCIAL } \\
\text { SERVICES }\end{array}$ & Novartis \\
\hline $\boldsymbol{M O N S A N T O}$ & Diageo & PepsiCo \\
\hline $\boldsymbol{C I S C O}$ & HYATT & Ernst \& Young \\
\hline $\boldsymbol{A M E R I C A N}$ & MARS & Intel \\
\hline SCORESS & Accor & General Mills \\
\hline $\boldsymbol{S C J O H A B A N K}$ & EBAY & Novo Nordisk \\
\hline
\end{tabular}

Leyenda: en mayúscula son las organizaciones que mantienen un posicionamiento estable en la clasificación, en los tres años indicados; en mayúsculas y negritas aquellos cuya posición es estable y en crecimiento; aquellos en mayúsculas con fondo gris son las nuevas organizaciones que han entrado este año en la clasificación; con minúsculas son aquellos que están perdiendo posiciones o que, en el último año, ya no están entre los primeros 25 .

Casi la mitad de las empresas en cuestión (48\%) tienen altas facturaciones y una cierta influencia en las redes sociales. De hecho, al menos indirectamente, quiere decir que estas empresas tienen unos niveles de credibilidad y reputación en el mercado y en la red en la que circulan vídeos. 
Por cada una de las 21 empresas, se estima el valor en términos de ingresos anuales (Fortune 500, 2014) ${ }^{2}$, y la influencia y el atractivo en el mundo social (Interbrand, 2014):

Tabla 2 - Las posiciones de las empresas multinacionales examinadas

\begin{tabular}{|c|c|c|}
\hline $\begin{array}{c}21 \text { World's Best } \\
\text { Multinational Workplaces } \\
(2012-2014) \\
\end{array}$ & $\begin{array}{c}\text { Fortune } 500 \text { global } 2014 . \\
\text { Posición entre los } \\
\text { primeros } 500(41 \%) \\
\end{array}$ & $\begin{array}{c}\text { Interbrand } 2014 \\
\text { Posición entre los } \\
\text { primeros } 100(38 \%) \\
\end{array}$ \\
\hline Google & 162 & 2 \\
\hline SAS Institute & / & / \\
\hline NetApp & / & / \\
\hline Microsoft & 104 & 5 \\
\hline Marriott & 1 & 1 \\
\hline Monsanto & 1 & 1 \\
\hline Cisco System & 214 & 14 \\
\hline Diageo & l & l \\
\hline American Express & 333 & 23 \\
\hline Scotiabank & I & I \\
\hline SC Johnson & 121 & 78 \\
\hline Telefónica & 109 & / \\
\hline National Instruments & l & l \\
\hline FedEx Express & 236 & 92 \\
\hline Atento & / & / \\
\hline EMC & / & / \\
\hline Daimler Financial Services & 20 & / \\
\hline Hyatt & 1 & 1 \\
\hline Mars & / & l \\
\hline EBAY & / & 28 \\
\hline The Coca-Cola Company & 224 & 3 \\
\hline
\end{tabular}

El estudio sobre las 21 empresas identificadas se llevó a cabo a través de la realización de una encuesta que hizo uso de elementos textuales

\footnotetext{
${ }^{2}$ Fortune 500 examina el valor de las empresas multinacionales en el mercado a nivel mundial, teniendo en cuenta los ingresos anuales. Se habla de "empresa multinacional" cuando esa tiene una facturación de más de 3 billones de euros, igual al menos a $1 \%$ de la facturación total del país de pertenencia, con facturación en el extranjero de al menos un 10\% y presente por lo menos en otro país.
} 
y visuales a partir del análisis de $109^{3}$ vídeos producidos por las organizaciones en cuestión. El objeto principal de referencia es la historia de la compañía, para potenciar los niveles de visibilidad y credibilidad no solo a los clientes, socios, competidores, sino también al potencial "talento" para ser incluido en la organización, a fin de garantizar los niveles de conocimientos técnicos avanzados y altos estándares en términos de habilidades, eficacia operativa y eficiencia en la gestión y producción.

Los 109 vídeos seleccionados entre todos los que han realizado las empresas (315 según la investigación llevada a cabo en el período enero-marzo de 2015), fueron encontrados en los sitios web o en las web TV institucionales de las empresas. Cuando se publicaron también en YouTube, la investigación se llevó a cabo por palabras clave: "empleado", "puestos de trabajo", "reclutamiento", "trabajo", excluyendo los vídeos corporativos que se centran exclusivamente en la presentación de la empresa o de la actividad empresarial para el mercado (promoción de marcas, productos, servicios, soluciones financieras, etc.).

Los criterios para la selección de las informaciones se definieron a partir de una primera selección de vídeos y luego han sido reconducidos en la siguiente tabla:

Tab.3 - Los criterios de análisis del vídeo

\begin{tabular}{|c|l|}
\hline $\begin{array}{c}\text { Estructura } \\
\text { vídeo }\end{array}$ & $\begin{array}{l}\text { Película con imágenes, secuencias de vídeo con fotos, } \\
\text { entrevista, monólogo }\end{array}$ \\
\hline $\begin{array}{c}\text { Sección sitio } \\
\text { web }\end{array}$ & $\begin{array}{l}\text { Great Place at work, Empleo/Reclutamiento, Búsqueda de } \\
\text { trabajo, Buscar trabajos en Life, Equipo y Papel, Beneficios, } \\
\text { Reclutamiento de estudiantes; Desarrollo de trabajo }\end{array}$ \\
\hline canal YouTube & Si/No \\
\hline Tipo de vídeo & $\begin{array}{l}\text { Testimonios: Presidente/Director; equipo de gestión; } \\
\text { personal empleado; imágenes de la historia corporativa; } \\
\text { imágenes de la vida empresarial; guía a la empresa; imágenes } \\
\text { y presentaciones relacionadas con beneficios, instrucciones }\end{array}$ \\
\hline
\end{tabular}

\footnotetext{
${ }^{3}$ Cuando los mismos productos audiovisuales se publican tanto en los sitios web como en las web TV, se decidió considerar el producto más completo entre los dos.
} 


\begin{tabular}{|c|l|}
\hline & $\begin{array}{l}\text { sobre cómo presentarse a la entrevista de trabajo, pruebas } \\
\text { de habilidades. }\end{array}$ \\
\hline $\begin{array}{c}\text { Calculo de las } \\
\text { secuencias }\end{array}$ & $\begin{array}{l}\text { Número de secuencias dedicadas a elementos, en los vídeos, } \\
\text { como: testimonios, entrevistas, imágenes, diálogo. }\end{array}$ \\
\hline $\begin{array}{c}\text { Temas de las } \\
\text { secuencias }\end{array}$ & $\begin{array}{l}\text { Basándose en el contenido expresado: valor de } \\
\text { la empresa en términos de credibilidad, puntos } \\
\text { fuertes, posibilidades ofrecidas, } \\
\text { beneficios y ventajas para los empleados, } \\
\text { formación, modalidades de selección. }\end{array}$ \\
\hline $\begin{array}{c}\text { Análisis } \\
\text { eslogan }\end{array}$ & $\begin{array}{l}\text { Si hay, citar por extenso e identificar las palabras clave con } \\
\text { referencia a valores y estrategias. }\end{array}$ \\
\hline $\begin{array}{c}\text { Palabras clave } \\
\text { del vídeo }\end{array}$ & $\begin{array}{l}\text { Reportar todas las palabras significativas expresadas y el } \\
\text { número de veces }\end{array}$ \\
\hline "Testimonial" & Si hay, indicar su papel en la construcción de vídeo \\
\hline Narrador & $\begin{array}{l}\text { Si hay (entre o fuera de la escena) el estilo de comunicación } \\
\text { adoptado }\end{array}$ \\
\hline $\begin{array}{c}\text { Papel de } \\
\text { la música }\end{array}$ & $\begin{array}{l}\text { Simbólico, descriptivo u narrativo, de fondo, para resaltar } \\
\text { pasajes clave o marcar las secciones del vídeo, etc. }\end{array}$ \\
\hline $\begin{array}{c}\text { Estilo } \\
\text { comunicativo }\end{array}$ & $\begin{array}{l}\text { Descriptivos, narrativo, biográficos, de celebración, } \\
\text { enfáticos, irónicos, satírico, } \\
\text { concentrado sobre la sugerencia de las imágenes }\end{array}$ \\
\hline $\begin{array}{c}\text { Estrategias } \\
\text { encontradas }\end{array}$ & $\begin{array}{l}\text { Boca a boca, identificación, gratificación, implicación, } \\
\text { estímulo emotivo, disonancia, conformismo, dependencia. }\end{array}$ \\
\hline
\end{tabular}

\section{Resultados}

Junto a la revisión de sitios web corporativos, YouTube se confirma ahora como la plataforma más popular y extendida para compartir vídeos en todo el mundo y, por tanto, la más utilizada por las empresas, que activan canales corporativos. En estos se adoptan modelos de negocio dirigidos a aumentar la visibilidad en función de una inversión en las relaciones con los usuarios y otras partes interesadas. Dado que este fenómeno está bien establecido, se confirma esta práctica entre las 21 mejores empresas del mundo examinadas: de hecho, todos usan YouTube para subir vídeos y más de la mitad (57\%) tiene su canal de negocio.

En el conjunto de vídeos diseñados y desarrollados por las organizaciones, se destaca la función principal que cada vídeo tiende, prioritariamente, a cumplir: la mayoría tienen un carácter sobretodo comercial y promocional. Cumplen la tarea de presentar 
servicios y productos para el usuario final, para atraerlo y conseguir con una comunicación personalizada y orientada a satisfacer sus expectativas y necesidades.

Con este fin, los productos audiovisuales utilizan una comunicación muy convincente, rica en imágenes con alta intensidad emocional, con música de fondo creativa y capaz de estimular referencias y sugerencias, a veces acompañados de descripciones técnicas, en función de los objetivos específicos. La investigación en la construcción del producto se centra alrededor de la calidad iconográfica, la originalidad de los contenidos, la esencialidad del tamaño y la duración (alrededor de dos/tres minutos).

La segunda categoría de vídeo cumple una función típicamente institucional y se inscribe en la lógica de la comunicación corporativa: presentar la identidad empresarial destacando y exaltando los rasgos típicos de la misión y la visión. Las peculiaridades de las organizaciones se traducen bien en las películas llenas de imágenes que muestran la historia y el éxito a través del tiempo, la exaltación de los valores y principios comunes dentro de la comunidad empresarial, la innovación y la orientación al progreso en los procesos y en los productos, la sensibilidad en referencia a la sostenibilidad ambiental, el respeto de los derechos humanos, los problemas sociales y la búsqueda de resultados concretos en relación con ciertos asuntos importantes para la organización, etc.

Como en los vídeos promocionales, el estilo narrativo de este segundo tipo de vídeo es en su mayoría enfático, con elementos conmemorativos, imaginarios, de identificación y también contradictorios. A diferencia de los otros, estos son productos con una duración más larga (aproximadamente de 7-8 minutos) en los que es posible estructurar la historia en un relato sólo, o, en un conjunto de secuencias en cada de las cuales confiar la narración de temas, valores, palabras clave, etc.

Como parte de la producción audiovisual de tipo institucional, se incluye también los vídeos donde los trabajadores - y su entorno de trabajo - son los protagonistas del proceso de comunicación, tanto 
como objetos y como sujetos de la narración. La peculiaridad de estos productos es que abarcan un amplio abanico de propósitos además del reconocimiento inmediato de la identidad empresarial; son dispositivos de motivación válidos para los usuarios internos y los públicos interesados y se convierten en herramientas estratégicas para el "employer branding management", sobre todo cuando son capaces de ponerse en contacto con los talentos y con las personas con las credenciales apropiadas para la empresa y, no menos importante, son ayudas válidas para demostrar a los clientes el valor de la empresa.

De hecho, en estos vídeos están representando aspectos que ponen de relieve la calidad y la eficiencia de los procesos, la seguridad de servicios y productos, la presencia de un público de alto nivel de competencia profesional, la capacidad de interactuar en una comunidad sólida, coherente y capaz de mejorar continuamente sus normas para satisfacer las necesidades de los usuarios a los que la empresa está particularmente atenta y sensible. En última instancia, estos productos se van a añadir a los vídeos inmediatamente distinguibles como "institucionales" y, por eso, son cada vez más comunes, especialmente en las grandes organizaciones.

La diferencia entre los dos tipos de vídeos corporativos se percibe inmediatamente por la ubicación del vídeo y por la elección del nombre. Cuando están presentes en los sitios institucionales, la primera tipología se encuentra principalmente en las secciones de presentación ("Home", "Corporate") o "lugar de trabajo". Mientras que la segunda, en su mayor parte, se encuentra en las páginas dedicadas a "Carreras" y similares ("Reclutamiento", "Búsqueda de empleo", "Buscar en los trabajos", "Desarrollo") o "lugar de trabajo": todas tienen como objetivo describir las perspectivas de empleo y el clima laboral

Con respecto a los nombres, los vídeos institucionales "típicos" se basan en los elementos inmediatamente reconocibles de la identidad empresarial (por ejemplo: "Perfil de la empresa", "Historia de" o el uso de lemas, a menudo presentes en la misión o visión de la organización). Los que se centran en el lugar de trabajo y en los trabajadores se refieren al valor $y$ al placer de trabajar en la 
organización X, presentando la compañía como el mejor lugar para trabajar por las oportunidades, los valores, los beneficios, el entorno de trabajo, etc. ("La vida en el", "Trabajar en", "Mejor lugar de trabajo", "X empleados", "Comunidades de", "Entrevista en roles" o el uso de lemas qué expresan apreciaciones sobre el trabajo en la organización X.

El análisis llevado a cabo en esa última categoría de vídeo permite encontrar elementos adicionales de diferenciación de los vídeos institucionales "clásicos", tanto a nivel estructural como en las estrategias de embalaje.

En términos estructurales, y de embalaje, el primer elemento evidente es que lo vídeos tienen una duración más larga (la media detectada entre los 109 vídeos es de 5,2 minutos), pero también es muy variable (desde un mínimo de 1,29 a un máximo de 30 minutos). Esto se debe a dos factores principales: el primero está determinado por el estilo de comunicación que la empresa elige, a veces más atento a la lógica comercial, a veces a la corporativa.

No en vano, el estilo más sencillo es típico de las organizaciones en las que la mayoría de los vídeos producidos son comerciales, especialmente en el caso de las organizaciones que trabajan en el ámbito de los servicios financieros y la tecnología (por ejemplo: Sas, SC Johnson, Telefónica y EMC, con un promedio alrededor de 12,75 minutos); mientras que aquellos que dedican gran parte de la producción a la comunicación institucional tienden a resaltar la imagen de la empresa a través de la complejidad de los principios, valores y oportunidades (por ejemplo: American Express, FedEx Express, National Instruments, Microsoft y Monsanto, con un promedio de alrededor de 2,26 minutos).

El otro elemento de diferenciación se refiere al uso de la música. A diferencia de los tipos anteriores (comerciales y corporativos), en estos productos la música está prácticamente ausente en el 15\%. Cuando está presente, en la mayoría de los casos (75\%), se trata de una música de fondo que acompaña a la presentación de los momentos de la vida empresarial; sin embargo, en estos casos no hay 
correlaciones particulares entre los aspectos simbólicos que evocan los jingles empresarial y los rasgos de la identidad de la empresa. En los casos restantes, la música se utiliza para satisfacer requisitos técnicos o, más precisamente, para conectar secuencias o enfatizar cambios de tema.

En consecuencia, parece que la primera estrategia de edición es confiar casi exclusivamente en el mensaje hablado: en la mayoría de los casos son entrevistas, mientras que, cuando no está presente, la narración se encomienda a una vOz superpuesta que presenta las imágenes de lugares, procesos y personas. Si el uso de la música es mínimo, el uso de cualquier otro soporte se revela completamente residual. Sólo en casos raros (4\%), se usan fotos de grupos de empleados, mostrando diapositivas y etapas que describen el proceso de producción y, sobre todo, de las tarjetas presentadas por diversos trabajadores en cuyo caso hay algunas palabras clave. El conjunto permite subrayar el estilo de comportamiento típico de los trabajadores, o definir el valor de la empresa en términos de calidad ética, de acuerdo con lo indicado en la misión y la visión empresarial.

Se confirman como protagonistas de estos vídeos los trabajadores y los entornos en los que operan. Como intérpretes de una narrativa diseñada para enfatizar fortalezas, potencialidades y oportunidades de la organización, los trabajadores se convierten en testigos perfectos, tanto cuando son "sujetos", o son protagonistas de la historia (54\%), o cuando son objetos sobre los que se basa la historia (46\%).

Esta distinción -sujetos/objetos- con referencia al tipo de presencia de los trabajadores en los vídeos, es un elemento importante en la estructuración del formato. Los trabajadores toman la palabra directamente cuando se les confía el relato de la historia de las experiencias de relaciones y profesionales en la organización, con el fin de subrayar que en la empresa se está bien, además de poner el acento sobre la eficiencia de los procesos, la calidad de los servicios y productos, las oportunidades para el crecimiento individual y la combinación de los beneficios que se pueden disfrutar, así como el conjunto de valores y principios adoptados y respetados por la organización. Por el contrario, los trabajadores sólo asumen la 
función de testigos pasivos, filmados durante actividades de trabajo, ocio, etc., para presentar sujetos (presidente, un miembro del CEO, gerente de sectores o "expertos" profesionales) que cuentan algo de la empresa durante una entrevista.

Es posible identificar cuatro situaciones típicas en los vídeos, con el fin de establecer la función y el papel desempeñado por los principales protagonistas (v. Tab. 4):

Tab. 4 El papel de los trabajadores en la construcción de vídeos

\begin{tabular}{|l|c|c|}
\hline & Testigos activos & Testigos pasivos \\
\hline Presentación & $\begin{array}{c}\text { Trabajadores expertos } \\
(54 \%)\end{array}$ & Gerentes/CEO (35\%) \\
\hline Entrevista & Trabajadores (7\%) & CEO/Presidente (4\%) \\
\hline
\end{tabular}

En las narraciones en las que los trabajadores son objeto de los contenidos $(39 \%)$, la narración se confía sobre todo a la dirección empresarial o a los miembros de la CEO. El tono y el estilo son claramente institucionales y el objetivo es, en la mayoría de los casos, la presentación y exaltación del valor de la empresa (58\%), así como los beneficios obtenidos por los trabajadores (37\%) y, en algunos casos, se utilizan para presentar los puestos de trabajo vacantes.

A veces (5\%), estos vídeos están también dirigidos a los jóvenes, como reclutas potenciales, para presentar momentos de formación interna o guías reales para el trabajo o explicar las modalidades de selección y los pasos necesarios para lograr un puesto de trabajo. En un caso, por ejemplo, el vídeo presenta una conversación por skype que tuvo lugar entre los administradores que dan información útil sobre las diferentes áreas de la organización y las actividades realizadas.

Cuando está presente, el Presidente (el 2\% sobre el 39\% de los vídeos en cuestión), en su mayoría, es entrevistado por una voz superpuesta. Sólo en raras ocasiones se presenta la empresa con un largo discurso o se muestran extractos de una convención empresarial. 
En general, en estos vídeos centrados en la comunicación de la dirección empresarial, la función principal es motivar a los usuarios, tanto internos como externos, y exaltar los valores corporativos. Estos productos están dirigidos, por lo tanto, a los jóvenes, los talentos, los potenciales candidatos para los puestos de trabajo vacantes, pero también a los que ya trabajan o colaboran en la organización, con el fin de aumentar el sentido de pertenencia y hacer que se sientan "orgullosos" de ser parte de una comunidad cohesiva y eficiente.

Por el contrario, en casi dos tercios de los vídeos (62\%) el trabajador es un sujeto activo y por lo tanto se convierte en narrador y testigo de las actividades empresarial. Básicamente, están implicados en la ejecución, los profesionales "expertos" y, por tanto, capaces de contar los detalles específicos relacionados con los procesos, funciones y actividades (58\% vs. $42 \%$ en los que están presentes los trabajadores en cada categoría).

Para enfatizar la dimensión meramente laboral, una parte de los vídeos -sobre todo cuando son de breve duración- muestran entrevistas individuales de los trabajadores o unen entrevistas a diferentes categorías de empleados qué hablan de la gratificación conseguida en el trabajo, de las oportunidades de desarrollo y crecimiento profesional. En comparación con las referencias dedicadas al ambiente de trabajo, en la mayoría de los casos, todo el mensaje está destinado a acentuar el "valor relacional" (12\%), y el ambiente de trabajo se define como: colaborativo (75\%), apacible y amistoso (15\%), incluso, alentador y despejado (5\%).

La intención de los vídeos dedicados a los trabajadores y el ambiente laboral es la de dirigirse a los futuros empleados, presentando características, peculiaridades y beneficios potenciales de las posiciones de trabajo al fin de alentar las personas a que presenten sus candidaturas. El público en cuestión es muy específico y se refiere a los mejores talentos y los que ya colaboran en otras empresas, no necesariamente en busca de un trabajo, recurriendo a una comunicación estratégica, detallada, estimulante y orientada a la gratificación personal. En estos casos es necesario exhortar a los 
destinatarios a través de la creación de necesidades y expectativas porque no está dirigido a los talentos que buscan un empleo sino que es la empresa que promueve el vídeo con la intención y la necesidad de "encontrarlos" y atraerlos.

En este sentido, la tarea del profesional competente es llegar a ser una especie de "cazador de talentos" que lanza mensajes entre colegas y, como un "experto" -tanto en términos de trabajo que en términos de conocimiento de la vida empresarial- se convierte en el "líder de opinión ideal", es decir, el papel más creíble y valido para hacer frente a este tipo de usuarios tan especial e importante para las empresas.

Son pocos (el 10\% del 62\% de los vídeos en cuestión) los vídeos que se dirigen a los jóvenes, aprendices, estudiantes y potenciales futuros empleados. Estos últimos productos se empaquetan como guías actuales dedicadas a describir los perfiles típicos de la empresa, con el fin de informar y orientar; en otros casos se trata de productos que ayudan a mejorar el rendimiento para hablar en público, para hacer una breve presentación de sí mismo delante de una cámara o incluso preparar la entrevista de trabajo.

En este caso, estos videos muestran situaciones concretas de conversaciones que tienen como protagonistas los jóvenes aprendices. En estos últimos vídeos, los jóvenes cuentan sus experiencias y muestran momentos de su formación dentro de la empresa.

Otra parte importante, los vídeos tienen como protagonistas los trabajadores se dedica a acentuar oportunidades, beneficios y estilos de vida propios de la organización (38\%). A diferencia de la dirección empresarial, los empleados hablan poco (en el 5\% de 38\% de los vídeos en cuestión) de los valores corporativos y esto sólo ocurre cuando las imágenes de fondo son evocadoras o cuando se presentan palabras clave sobre la empresa en cuestión. En estos casos, el empleado siempre se eleva a líder de opinión creíble.

En general, este tipo de vídeos centrado en las oportunidades y beneficios tiene el deber de cumplir una gama más amplia de 
objetivos, en relación con el público estratégico: referirse a los colegas internos sirve para aumentar el sentido de pertenencia a través del intercambio de experiencias, emociones, valores, etc.; hacer una presentación destinada a los que están en busca de trabajo; crear un producto para conquistar también una audiencia más amplia de usuarios y consumidores, que pueden aumentar la reputación en la empresa, la seriedad y la eficiencia y apreciar el tratamiento y el cuidado de las personas en la empresa.

No es de sorprenderse, incluso en la estructuración del guión, que algunos de estos vídeos (el 8\% sobre el 38\% de los vídeos en cuestión) muestren una mayor atención en la inserción de elementos originales como el uso de las comparaciones entre los competidores o de las "secuelas". Algunos, de hecho, se construyen tomando el estilo de la secuela, como si fueran tantos episodios de una misma historia, en el que diferentes trabajadores relatan momentos de la vida corporativa o de entretenimiento entre los colegas; así que traen oportunidades para conocer a las otras personas que trabajan en diferentes lugares y en diferentes partes del mundo, poniendo en evidencia la participación a favor de causas sociales y del público de interés, etc.

Otros son el resultado de los concursos hechos dentro de la empresa, donde los trabajadores participan en la construcción de productos audiovisuales en los que deciden el contenido y las situaciones y los mejores productos entran en la página web o en la WebTV institucional. Las repercusiones de este tipo de productos, debido a su mayor originalidad, pueden llegar a ser mensajes virales en las redes internas y externas y, de este modo, pueden ampliar la visibilidad de la empresa.

En resumen, el análisis de los mensajes muestra que estos se definen en torno de algunos conceptos básicos, calibrados de forma diferente dependiendo de su estructura, objetivos y público. El estudio de las palabras clave en torno a las cuales se estructuran el título del vídeo y el contenido principal del mensaje confirman el papel central de los temas conceptuales predominantes (Tab.5.): "Trabajo" (45\%), "lugar de trabajo" (36\%), "red" (10\%), "testigos" (6\%), "lealtad" (3\%). 
El trabajo es el tema central de los vídeos examinados, especialmente en relación con las actividades de trabajo (42\%) y luego en referencia a las oportunidades de carrera y desarrollo profesional (37\%). En los vídeos en los que los protagonistas son los directores ejecutivos, muchos de los contenidos acentúan el papel de los recursos humanos para crear el mejor ambiente de trabajo posible (11\%). En este sentido se presentan, aunque en pocos casos, las posiciones abiertas $(3 \%)$ y la atención se centra sobre las actividades de tutoría como estratégicas para permitir una mejor integración en la empresa y la identificación de las etapas de carrera (2\%). En este sentido, dicho contenido confirma el papel estratégico de estos productos en el campo de la gestión de estrategias de "employer branding", tanto para los trabajadores en busca de empleo, como los talentos.

Tab. 5 - Las palabras clave en los vídeos

\begin{tabular}{|c|c|c|c|c|}
\hline $\begin{array}{c}\text { Trabajo } \\
(45 \%)\end{array}$ & $\begin{array}{c}\text { Sitio para trabajar } \\
(36 \%)\end{array}$ & $\begin{array}{c}\text { Network } \\
(10 \%)\end{array}$ & $\begin{array}{l}\text { Testigo } \\
(6 \%)\end{array}$ & $\begin{array}{c}\text { Fidelidad } \\
(3 \%)\end{array}$ \\
\hline $\begin{array}{l}\text { Trabajo }(42 \%) \\
\text { Carera }(26 \%) \\
\text { Oportunidades } \\
(11 \%) \\
\text { Gestión de los } \\
\text { recursos } \\
\text { humanos }(7 \%) \\
\text { Learning }(5 \%) \\
\text { Experience } \\
(4 \%) \\
\text { Despacho }(3 \%) \\
\text { Políticas de } \\
\text { contratación } \\
(2 \%) \\
\text { Beneficios }(2 \%) \\
\text { Tutoría }(2 \%)\end{array}$ & $\begin{array}{l}\text { Mejor sitio (31\%) } \\
\text { Diversidad/inclusión } \\
\text { /mujeres/migrantes } \\
(21 \%) \\
\text { (familia)empresa/ } \\
\text { destino }(18 \%) \\
\text { Futuro/innovación } \\
(18 \%) \\
\text { Valor }(10 \%) \\
\text { Vida }(8 \%) \\
\text { Cultura }(5 \%) \\
\text { Sueño/sin límites } \\
(5 \%) \\
\text { Equilibrio } \\
\text { trabajo-vida (3\%) }\end{array}$ & $\begin{array}{l}\text { Network }(45 \%) \\
\text { Comunidad/ } \\
\text { nosotros somos } \\
(18 \%) \\
\text { Equipo }(10 \%) \\
\text { Pasión }(10 \%) \\
\text { Bienvenido }(9 \%) \\
\text { Sonrisa }(8 \%)\end{array}$ & $\begin{array}{l}\text { Testigo } \\
(56 \%) \\
\text { Entrevistas } \\
(44 \%)\end{array}$ & $\begin{array}{l}\text { Amor } \\
(67 \%) \\
\text { Atraer/ } \\
(33 \%)\end{array}$ \\
\hline
\end{tabular}

Total: 6.050

- El segundo tipo de mensaje en cuestión se centra en el lugar de trabajo y, por supuesto, éste se presenta como la mejor posibilidad en el mercado (31\%). Las temáticas y los contenidos de los vídeo justifican esta afirmación: en primer lugar, se refiere a la atención que la empresa presta a todos los trabajadores, en particular a los "grupos desfavorecidos" (mujeres y migrantes), a través de la activación de políticas para promover la integración, la inclusión y el respeto a la 
diversidad (21\%). No es de extrañar, pues, que la empresa se presente como una especie de "familia" muy atenta al bien de cada uno de sus componentes (18\%). También se presenta como el lugar perfecto para alojarse, ya que es una organización capaz de mirar hacia el futuro con un plan centrado en la innovación (18\%) y con un conjunto de valores que caracterizan el estilo y la cultura de la empresa $(15 \%)$;

- Gracias a la calidad de las relaciones internas y el buen equilibrio entre la vida laboral y la vida personal (11\%), la empresa se sitúa como una meta y un sueño hecho realidad, en lugar en el que crecer y experimentar sin obstrucción o interferencia (5\%). Estos factores hacen que estos contenidos sean perfectos para abordar a los talentos que se encuentran en el mercado laboral y justifican el papel de "cazador de cabezas" de los trabajadores. No en vano, en más de dos tercios de los vídeos donde estas palabras clave son significativas, la comunicación se encomienda directamente a los trabajadores, en lugar de a los directores.

- La tercera categoría de contenidos se refiere a los aspectos relacionales. Se señala, de hecho, el valor de la empresa en su comunidad, como una red en la que los trabajadores operan en equipos, en sinergia dentro de un ambiente colaborativo. Todo favorece la propagación del sentido de pertenencia, que es un aspecto gratificante por el hecho de trabajar en la misma organización (73\%). Para amplificar este concepto se acentúan la pasión con la que los trabajadores afrontan los empeños diarios $(10 \%)$ y la atención a los procesos de bienvenida a los nuevos empleados y, en general, a todos aquellos que entran por primera vez en la empresa (9\%). En este sentido, en un vídeo donde la comunicación está a cargo de los directores, se explica la idea de que uno tiene que enfrentar los problemas siempre con alegría y con una sonrisa (8\%). Este es un mensaje dirigido indistintamente a todas las categorías de usuarios: desde los internos hasta los que están fuera, incluidos los consumidores y a los empleados potenciales que pueden apreciar mejor la organización como un sistema complejo de valores, acciones, estilos de comportamiento, etc. No es sorprendente que 
este tipo de mensaje tenga como protagonistas a todas las categorías de trabajadores de la empresa.

- Las dos últimas categorías de palabras clave, aunque tienen un valor residual en términos cuantitativos, completan la estructura de los contenidos de los vídeos. Una categoría marca el valor de los testigos $(6 \%)$ y también la elección de las entrevistas como herramienta para comprender mejor los diferentes aspectos de la vida laboral. Estas palabras clave se pueden encontrar especialmente en aquellos productos en los que los protagonistas son los trabajadores y que están dirigidas especialmente a los jóvenes. Estos contenidos a menudo se centran en las guías de negocio y en las entrevistas de trabajo.

- La última categoría de palabras clave se refiere a la "fidelidad" $(3 \%)$, evidenciada por dos conceptos clave: el amor por la empresa en la que se trabaja y el empeño de la empresa por el bien de la comunidad externa. Son aspectos que confirman lo que la organización quiere decir: o sea que es el mejor sitio para trabajar, la mejor comunidad de personas y la más eficiente $\mathrm{y}$, por lo tanto, todos están orgullosos de ser parte de la empresa.

\section{Conclusiones}

El estudio de los procesos de construcción de una narración polifuncional confiada a los vídeos y amplificada por la red, confirma el valor del "videosharing" como herramienta para satisfacer las intenciones de las empresas de narrar sus historias para alimentar el nivel de visibilidad y credibilidad para los clientes, socios, competidores así como para los talentos potenciales. De hecho, el aprovechamiento de la tecnología audiovisual -especialmente cuando se combina con las plataformas digitales- significa adoptar niveles avanzados de experiencia y altos estándares en términos de habilidades, eficacia operativa y eficiencia en la gestión y producción empresarial (Amendola 2008, Ahammada, Tarbab, Liuc, Glaisterd, 2014). Ya el simple hecho de tener los medios adecuados para gestionar la comunicación en su forma actual y, más importante, ser capaz de producir estas herramientas es un primer elemento de reconocimiento, distinción y credibilidad. 
Realizar estratégicamente los contenidos, con referencia a las expectativas de los diferentes públicos y mercados, es, ante todo, una tarea esencial para una empresa que quiere hablar con todo el mundo y, más importante, ser competitiva. Así, cuanto más se complejiza la red de relaciones en torno a una organización, más importante es prestar atención a todos los elementos que implementan la reputación de la empresa, entendidos no solo como el índice de popularidad para los socios y empleados, sino como conjunto de percepciones, juicios y consideraciones que sustentan los niveles de confianza y credibilidad de la empresa y, por lo tanto, la estabilidad en el campo de las relaciones públicas (Carroll, 2015).

Si este conjunto de factores es fundamental para garantizar el buen curso de la empresa en el mercado laboral, con más razón, la reputación se convierte en un recurso determinante y representativo de la identidad empresarial, del valor y del comportamiento de la organización misma. Algunos autores subrayan, además, como el capital de reputación (Siano, 2012) es una calidad única e inimitable, un rasgo distintivo que se convierte en signo de identificación, ( $\mathrm{Yu}$ Wu, 2010) y, por eso, es un elemento clave para la ventaja competitiva de la empresa. No en vano, el "reputational risk" es el principal riesgo de la empresa contemporánea (Economist Intelligence Unit, 2005), a punto de ser examinado y evaluado como indicador básico en los recientes estudios de la economía cognitiva y de los comportamientos de negocio (Kahneman e Tversky, 1974, 1979; 2002; Legrenzi, 2006; Zweig, 2007; Peterson, 2007; Rubaltelli, 2008).

En este sentido, los vídeos de los trabajadores son perfectos porque se convierten en "escaparates" ideales en los que los líderes de opinión pasan la voz a diferentes categorías de personas, siempre al día en lo que se refiere a la vida empresarial. Los trabajadores, como expertos en la empresa, tienen credibilidad para presentar la realidad y crear mecanismos de identificación (Morin, 1962) para los potenciales empleados. Para probar esta hipótesis, se han presentado los resultados de un trabajo de análisis desarrollado en aquellas empresas que, al menos durante los últimos tres años, han sido las mejores a 
nivel internacional por la calidad, el valor y la credibilidad de su funcionamiento interno.

El trabajo sobre la reputación es continuo por el hecho que es necesario adoptar un estrategia de comunicación que complementa las herramientas con o sin conexión, que permiten maximizar las posibilidades para que la exposición sea eficaz, acentuando los elementos de positividad y eliminando los elementos negativos. Esto implica, como recordó David F. Carr, director de The BrainYard, en el número de julio de 2012, que es fundamental la elaboración de directrices para apoyar el papel de embajador de los empleados, en la medida en que los efectos pueden reflejarse directamente en la organización. El tratamiento de la reputación no sólo sirve para garantizar la difusión de una buena imagen (Túñez, 2012), sino que implica la necesidad de crear un conjunto de impresiones y percepciones para todos los sujetos interesados.

Junto a las acciones llevadas a cabo en términos de marca corporativa y desde una perspectiva comercial, el peso de la reputación en el mercado de trabajo favorece la producción de vídeos en los que los trabajadores son protagonistas. Se trata de una comunicación directa "peer to peer" en la que se activa una estrategia a largo plazo dirigida a administrar la conciencia y la percepción de los que ya son empleados y los futuros trabajadores (Sullivan 2004: 74), que muestran la organización como "un gran sitio para trabajar" y, en ese sentido, hacen que los usuarios quieran ser parte de la misma, en primer lugar como empleados, pero también como consumidor.

Momentos de trabajo, relaciones personales, congresos y eventos, sesiones de entrenamiento y perspectivas futuras de trabajo son la mezcla de ingredientes para realizar una representación válida de la experiencia de la empresa, con la que identificarse y a la que pertenecer. Si la receta básica está bien establecida, al menos en las mejores empresas, lo que debe fortalecerse es el toque de originalidad. El riesgo es, de hecho, lo de ser menos deseable, dada la rápida difusión y el uso generalizado de los vídeos. Aquí es el ingrediente esencial a fin de no repetir siempre "la misma historia". 


\section{Referencias}

Ahammada M.F., Tarbab S.Y., Liuc Y., Glaisterd K.W. (2014), Knowledge transfer and cross-border acquisition performance: The impact of cultural distance and employee retention, in International Business Review, 14 July, Elsevier, Leida

Amendola E. (2008), Corporate Recruiting. Employer Branding e nuove tendenze, Anthea Consulting s.r.l., Bologna

Bolter J.D., Grusin R. (2003), Remediation. Competizione e integrazione tra media vecchi e nuovi, Guerini e Associati, Milano

Burson-Marsteller, The Third Annual Global Social Media Check-Up 2012, http://sites.burson-marsteller.com/social/Summary.aspx

Cappelli P., Keller J.R. (2014), Talent Management: Conceptual Approaches and Practical Challenges, Annual Review of Organizational Psychology and Organizational Behavior, Volume 1, January 2014, p. 305-332, www.annualreviews.org

Carr D.F. (2012), Editorial: Social Media For Grownups: Every company needs a social networking policy, but don't stifle creativity and productivity with too much formality, in The Brain Yard, UBM, London, July

Carroll C.E. (edited by, 2015), The Handbook of Communication and Corporate Reputation, Wiley-Blackwell, New York.

Cuomo M.T., Tortora D., Metallo G: (2014), Corporate Reputation Management. Analisi e modelli di misurazione, Seconda Edizione, Giappichelli Editore, Torino

Davies H., Moir S. (2012), Employer Branding. Case studies and comments from industry professionals, BookPal, http://www.barnesandnoble.com/sample/read/9781742841342

Economist Intelligence Unit (2005), Reputation: Risk of Risks, bttp:/ / www.eiu.com/ report dl.asp? mode $=$ fieffi=1552294140.PDF

Fortune 500 (2011), Global 500, http://fortune.com/global500/2011/

Fortune 500 (2014), Global 500, http:// fortune.com/global500/

Genco P. (2014) Corporate Governance. Sistemi e strutture di governo dell'impresa, Giappichelli Editore, Torino

Great Place to Work Institute, 2012 World's Best Multinational Workplaces, http://www.greatplacetowork.com/bestcompanies/worlds-best-multinationals/the-list 
Great Place to Work Institute, 2013 World's Best Multinational Workplaces, http://www.greatplacetowork.com/bestcompanies/worlds-best-multinationals/the-list

Great Place to Work Institute, 2014 World's Best Multinational Workplaces, http://www.greatplacetowork.com/best-companies/worldsbest-multinationals/the-list

Johansson C., Ottestig A.T. (2011), Communication executives in a changing world: Legitimacy beyond organizational borders, in Journal of Communication Management, Vol. 15 Iss.2, Emerald Group Publishing Limited, Howard House, UK, pp.144-164 Katz, E. \& Lazarsfeld, P.F. (1955) Personal influence: The part played by people in the flow of mass communications, The Free Press, New York.

Kahneman D., Tversky A. (Sep. 27, 1974), Judgment under Uncertainty: Heuristics and Biases, Science, New Series, Vol. 185, No. 4157. pp. 1124-1131

Kahneman D., Tversky A. (Mar., 1979), Prospect Theory: An Analysis of Decision under Risk, Econometrica, Vol. 47, No. 2. (Mar., 1979), pp. 263-292

Kahneman D., Prize Lecture (December 8, 2002) by, Princeton University, Department of Psychology, Princeton, NJ 08544, USA

Interbrand (2014), Rankings, http://www.bestglobalbrands.com/2014/ranking/

Invernizzi E. Romenti S. (2011), La valutazione dei risultati della comunicazione aziendale: quali sviluppi?, in Sinergie, Rivista di studi e ricerche n. 86/05, CUEIM Comunicazione srl, Verona

Lamborghini B. (2009), L'impresa web. Social Networks e Business Collaboration per il rilancio dello sviluppo, Franco Angeli, Milano

Legrenzi P. (2011), I soldi in testa. Psicoeconomia della vita quotidiana, Laterza, Roma-Bari

McKinsey Global Survey results (2009), How companies are benefiting from $W e b$ 2.0, September, http://www.mckinsey.com/insights/business technology/how companies are benefiting from web 20 mckinsey global s urvey results

Morin E. (1962), L’Esprit du temps: essai sur la culture de masse, Grasset, Paris 
Rubaltelli E., Pasini G., Rumiati R., Olsen R.A., Slovic P. (2010). The influence of affective reactions on investment decisions, in Journal of Behavioral Finance, 11, 168-176.

Siano A. (2012), La comunicazione per la sostenibilità nel management delle imprese, in Sinergie, Rivista di studi e ricerche n. 89, SettembreDicembre, CUEIM Comunicazione srl, Verona, pp. 3-23

Stelzner M.L (by 2013), 2013 Social Media Marketing Industry Report How Marketers Are Using Social Media to Grow Their Businesses, Social Media Examiner, http://www.socialmediaexaminer.com/SocialMediaMarketingI ndustryReport2013.pdf

Stelzner M.L (by 2014), 2014 Social Media Marketing Industry Report. How Marketers Are Using Social Media to Grow Their Businesses, Social Media Examiner, http://www.socialmediaexaminer.com/SocialMediaMarketingI ndustryReport2014.pdf

Toschi L. (2011), La comunicazione generativa, Apogeo, Milano

Túñez M. (2012), La gestiòn de la comunicaciòn en las organizaciones, Comunicaciòn Social ediciones y publicaciones, Zamora

Valdani E., Bertoli G. (2010), Mercati internazionali e marketing, Egea, Milano

Yu Wu (2010), Aplicability of the resource-based and dynamic capability views under enviromental volatility, in Journal of Business Research, Volume 63, Issue 1, January, Elsevier Inc., Leida, pp. 27-31 



\section{II \\ Comunicación Externa}





\section{De los atrezzos comunicativos}

Begoña Bueno Fernández

Universidad de Alicante

\section{Resumen}

Entre las técnicas y actividades que desarrollan las empresas públicas y privadas para conseguir sus objetivos comunicacionales no hay que menospreciar, en ningún caso, al protocolo y al ceremonial. Es más, el protocolo en la actualidad se concibe como un valor más dentro de la política de comunicación de la empresa que complementa la labor del marketing, potencia la publicidad, alimenta el gabinete de comunicación y estimula las relaciones públicas. Es más, el protocolo puede considerarse una forma de comunicación persuasiva que nos ayudará a conseguir una imagen positiva de nuestra organización y observamos a los jefes de protocolo como creadores de actos comunicativos.

Además, cualquier detalle, por mínimo que sea puede marcar la diferencia y puede suponer que un acto sea un éxito o todo un fracaso, con las consecuencias de imagen corporativa que esto supone.

Palabras clave: Protocolo, Ceremonial, Estrategia, Imagen Pública, Comunicación

\section{La comunicación institucional a través del protocolo}

T AS Relaciones Públicas, en su afán de lograr la confianza de las Lentidades con sus públicos, utilizan estratégicamente las funciones del ceremonial y el protocolo en los eventos, tanto en 
instituciones públicas como privadas. A través de estos canales comunicativos, se logran transmitir mensajes y signos identitarios organizacionales a los distintos públicos.

Este hecho queda constatado en las aportaciones de Otero (2002: 82): "El protocolo cumple unas funciones de primerísimo nivel que se enmarcan en el proceso de gestión de las relaciones públicas de las organizaciones. Es el responsable de mostrar el mensaje institucional a través de fórmulas de comunicación no verbal que se engloban en un sistema ceremonial, y constituye por sí mismo un lenguaje y un código a la vez únicamente descifrable por los iniciados pero cuyos efectos repercuten en todo el público expuesto a dicho mensaje."

Por otra parte, tomando palabras de la misma autora (2006: 257), no se trata de inventar noticias, sino de generar noticias reales que sirvan a los objetivos de la organización. De hecho, la autora nos señala: "El estado, el poder, las instituciones son entidades intangibles que necesitan tomar cuerpo, hacerse visibles ante los ciudadanos, para poder ser percibidas, aceptadas y legitimadas. Por eso las altas instancias del poder buscan la conexión con sus actores sociales a través de las celebraciones públicas, que actúan como vehículo transmisor de su identidad y de su mensaje, coadyuvando en la construcción de su imagen pública..."

Por lo que respecta a la concepción del término protocolo -presente en todas las culturas a lo largo del tiempo como forma de expresión ante el público- se ha transformado con el transcurso y evolución de los acontecimientos históricos, sociales y empresariales. Como indica Casal (2013: 762): "El Protocolo y el ceremonial nacen con la sociedad misma, cuando los individuos se organizan en grupos y necesitan herramientas de convivencia pacífica y exaltación de las posiciones hegemónicas."

No obstante, el avance en la historia y junto a ella en todos los estratos, manifestaciones sociales, organizacionales e institucionales, ha llevado a la reforma, evolución y amplitud de esta disciplina, como refrenda Fuente (2007): "Frente al protocolo de ayer, aquél que pretendía reflejar el poder de las autoridades, su fortaleza frente al 
mundo y la sociedad mediante un pomposo ceremonial y una rígida etiqueta... surge un nuevo Protocolo que pretende alcanzar, armoniosamente, una buena organización y transmitir comunicación cuando el acto es pensado para llegar más allá del mero foro de invitados presentes."

Además, tal y como expresa Campos y César (2010: 186), para demostrar la evolución de la materia y la amplitud de la misma: "El protocolo se presenta también como una disciplina de suma importancia en las relaciones institucionales e internacionales, convirtiéndose en el elemento vertebrador de las relaciones entre partes y su puesta en escena para hacer posible la consecución de los objetivos institucionales y empresariales que se determinen en cada caso."

En consecuencia, de la correcta aplicación de las normas de protocolo, dependerá la adecuada percepción del mensaje que se desea transmitir.

\section{E1 ceremonial}

En todo el entramado estratégico mostrado no hay que olvidar el papel del ceremonial. RAE (2014): "Serie o conjunto de formalidades para cualquier acto público o solemne", que como señala Weil (1992) está compuesto: "Por elementos materiales como los constitutivos de la escenografía, la decoración o la vestimenta, pero también por otros inmateriales como la música, los olores, las manifestaciones verbales, la gestualidad y los movimientos de los participantes".

Del mismo modo, como corroboran las palabras del autor anteriormente señalado, la utilización de sus componentes coadyuvan a generar un locum in unum de la comunicación no verbal.

Por tanto, es en este universo simbólico donde cobra todo su valor el ceremonial. Ya que como expresa Otero (2001: 15): "Esa convención se convierte en un agente ordenador, legitimador y jerarquizador que deja totalmente clara la estructura social de ese colectivo cuando ha de presentarse en público por sí mismo. En ese punto es donde 
encontramos ubicados al ceremonial y el protocolo y su razón de ser en las relaciones públicas".

\subsection{Ejemplo de aplicación del ceremonial en la institución} pública universitaria: Ceremonial en los Actos de Investidura de Doctores Honoris Causa

Así, por ejemplo, el Rector de la Universidad de Alicante, en el acto de Investidura de Doctores Honoris Causa, teniendo en cuenta la simbología de la liturgia en concreto, a la hora de investir al nuevo Doctor relata: "Os impongo este birrete cual corona de vuestros estudios y méritos". El Rector impone el birrete al Doctor Honoris Causa.

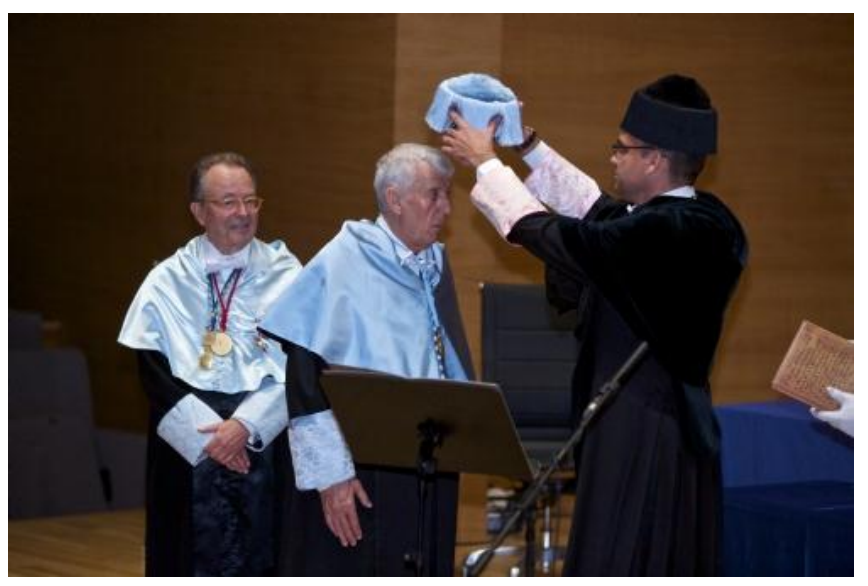

Fuente: http://goo.gl/UK6XpP

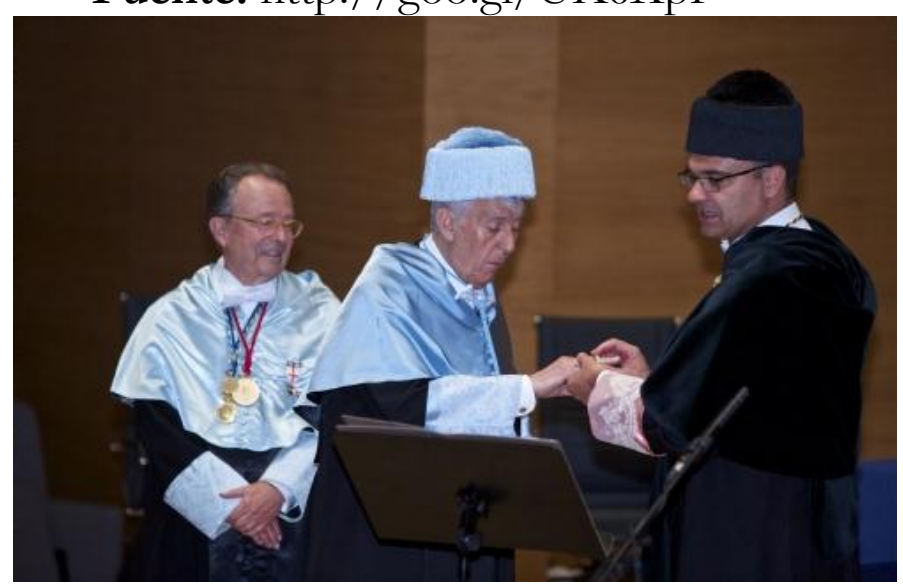

Fuente: http://goo.gl/a4PnCu

A continuación dice: "Ahora os entregaré los atributos de este nombramiento y distinción y os explicaré su significado". El Rector 
muestra al candidato el Libro de la Ciencia abierto y dice: "He aquí el libro que simboliza los secretos de las Ciencias".

Posteriormente, le impone el anillo mientras dice: "En vuestra mano pongo este anillo de oro como símbolo de vuestra unión con la Ciencia y con esta Universidad". Por último, entrega los guantes blancos diciendo: "Recibid, en fin, los guantes blancos, como símbolo de la pureza y la fortaleza que vuestras manos han de conservar, y también como signo de vuestra altísima dignidad".

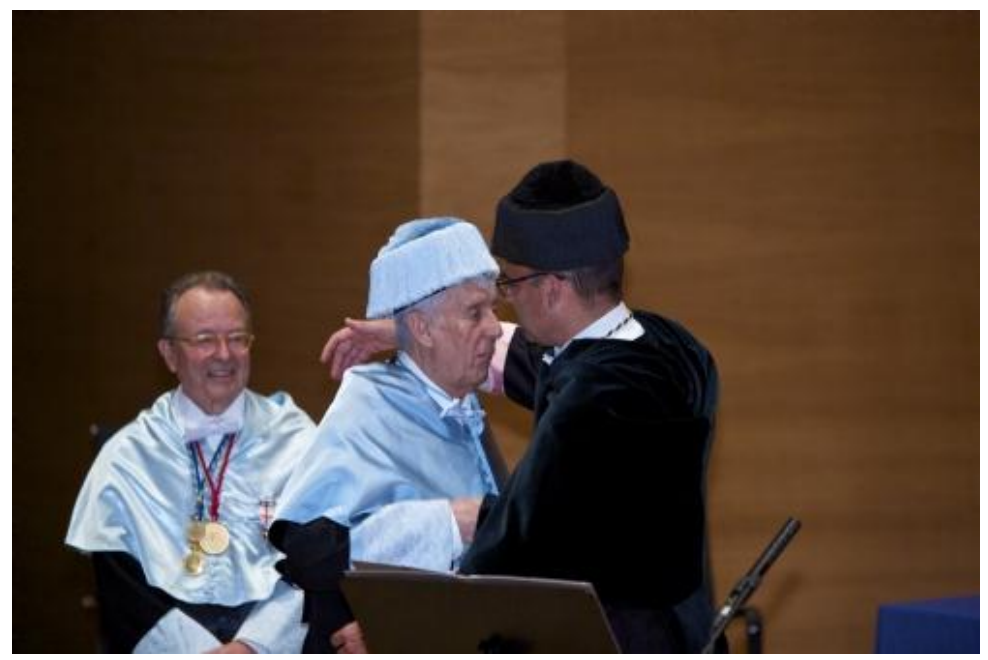

Fuente: http://goo.gl/FiAWP8

A continuación el rector dice: "Ahora os abrazaré para indicar nuestro mutuo afecto y fraternidad". El Rector abraza al Doctor Honoris Causa. Finalmente, le hace entrega del título de Doctor Honoris Causa.

\section{Los eventos institucionales}

Tal y como plasma Otero (2002: 135): "La gestión de la identidad, la imagen y la reputación de las organizaciones es una de las funciones principales de las relaciones públicas, y su vinculación directa a los procesos directivos está justificada por su incorporación a la cuenta de resultados como el principal activo inmaterial a considerar hoy".

Como se ha expuesto en el apartado anterior y parafraseando las palabras de Campos y César (2010: 187): A través del protocolo, de las relaciones institucionales y de los actos empresariales y 
corporativos, se puede mostrar una radiografía de las organizaciones y sus interrelaciones, mediante una cuidada puesta en escena no exenta de complejos planteamientos técnicos y artísticos como contenedores de los mensajes y valores que se quieren trasladar. Las empresas e instituciones demandan actos que propicien una comunicación más eficaz, optimicen resultados y causen impacto.

Estas exigencias están provocando el desarrollo de nuevos formatos de actos, casi tantos como los que se realizan, porque son actos a medida, pensados para satisfacer las necesidades y expectativas del cliente y alcanzar los objetivos planteados. Esto es así puesto que según Campos y César (2010: 201): "Los actos comunican, trasladan la imagen, el estilo y la responsabilidad social empresarial o corporativa de una organización. Por esa razón, el protocolo se erige en una herramienta estratégica en la comunicación organizacional".

Consiguientemente, siguiendo en la misma línea, y recogiendo la información reflejada por Otero (2001: 14): "Desde una perspectiva relacionista, el objetivo de los eventos aparece vinculado a la creación o reforzamiento de una positiva imagen corporativa, pero sobre todo a la invención de un espacio y un tiempo comunes que impulsen a los sujetos emisor y receptor de la acción a in unum locum conveniere, reunirse todos en un lugar, estado, situación o punto común favorable. Las excusas pueden ser muchas, desde acudir a una toma de posesión hasta asistir a una gala, pasando por participar en un congreso o tomar parte en una junta general de accionistas".

\section{Identidad e imagen corporativa}

\subsection{Imagen corporativa}

Según el Portal de Relaciones Públicas.net (2014), tomando las palabras Joan Costa, la Imagen Corporativa se puede definir como: "La representación mental, en el imaginario colectivo, de un conjunto de atributos y valores de la organización que funcionan como un estereotipo y determinan la conducta y opiniones de esa colectividad".

Esta representación mental en el imaginario colectivo requiere que sea positiva, que constituya una imagen efectiva de la institución para 
que sea condicionante del éxito empresarial. Sin embargo una imagen positiva es algo sobre lo que no se puede tener un control absoluto, dado que nace en la mente de los públicos y se va construyendo gracias a una multiplicidad de actos que esa empresa protagoniza; esto proporciona, a la Imagen Corporativa, una naturaleza intangible, que se convierte en su primera propiedad, confiriendo una gran complejidad al concepto.

Por tanto, tal y como señala Otero (2000): "Lo que llamamos imagen corporativa es el resultado que el conjunto de los comportamientos de una organización produce en la mente de sus públicos, y no se refiere tan sólo a las constantes de identidad gráfica, sino que integra el conjunto de imágenes que la organización proyecta al exterior”.

En esta perspectiva de la Imagen Corporativa, tomando reflexiones de Villafañe, J. (1999), sabemos que la Identidad de la empresa (constituida por un conjunto de rasgos y atributos, visibles o no, que definen su esencia), funciona como el estímulo que provocará una experiencia (que será la propia Imagen) en el receptor, mediada por él (sus prejuicios, sus presunciones, actitudes, opiniones, gustos, etc.) y por la naturaleza de un trabajo corporativo (conformado por todas las actuaciones, voluntarias o no, con intención comunicativa o sin ella, que hacen identificar, en la mente de los públicos, la imagen y la identidad de la empresa), que tratará de hacer coincidentes la parte estimular y la conceptual.

En este sentido, el único campo de actuación que le queda a la empresa para configurar una imagen positiva es el trabajo corporativo que hay que llevar a cabo. Lo que el trabajo corporativo no podrá conseguir nunca, es crear una imagen de algo que no existe, por ello, siempre debe basarse en la identidad propia de la empresa, tratando de conseguir una imagen intencional que induzca una posible imagen pública de la empresa a partir, entre otros, de la comunicación corporativa de la organización.

\subsection{La identidad corporativa}

La identidad corporativa, aquella que logrará conformar en los públicos una imagen positiva de la institución, estará compuesta, 
entre otros elementos, por sus signos distintivos, entre ellos, el protocolo y ceremonial universitario. Así, gracias a ellos, si se organizan convenientemente, los públicos podrán conceptualizar una imagen positiva de la institución y esta imagen generará a largo plazo una óptima reputación en la entidad. Esto es así ya que, tal y como indica Villafañe (1999: 1), "Aunque el valor de la imagen corporativa no figure en el balance de una empresa, ya nadie duda de su influencia en los procesos de generación de valor. No obstante, la gestión de la imagen corporativa es todavía hoy una actividad profesional no consolidada completamente por carecer de una visión global y de una sistematización de los procedimientos y de las técnicas que garanticen un control sobre sus resultados similar al de cualquier otra política corporativa."

Para la consecución de lo anterior, Weil (1992: 49) afirma que "la única manera de constituir la verdadera identidad de la empresa es establecer un sentimiento de pertenencia basado en un espíritu, una concepción singular del oficio, un saber hacer, una filosofía, incluso una ética, erigida en estandarte". Esta situación transforma al grupo en comunidad, planteándose la necesidad de exteriorizar su mensaje enarbolando los signos en los que cree (divisas, heráldica, logotipos, colores, emblemas, banderas, estandartes, etc.), que forjan su identidad y valores.

Con todo es necesaria la existencia de gabinetes de protocolo responsables de la planificación, organización y ejecución de actos de carácter oficial en el ámbito de las instituciones, con tres objetivos primordiales:

- Transmitir respeto y acercamiento hacia la institución

- Potenciar la imagen

- Cristalizar la buena reputación.

\section{Conclusiones}

Entre las técnicas y actividades que desarrollan las empresas públicas y privadas para conseguir sus objetivos comunicacionales no hay que menospreciar, en ningún caso, al protocolo y al ceremonial. Es más, 
el protocolo en la actualidad se concibe como un valor más dentro de la política de comunicación de la empresa que complementa la labor del marketing, potencia la publicidad, alimenta el gabinete de comunicación y estimula las relaciones públicas. Es más, el protocolo puede considerarse una forma de comunicación persuasiva que nos ayudará a conseguir una imagen positiva de nuestra organización y observamos a los jefes de protocolo como creadores de actos comunicativos. Pero, ¿por qué esto es así?

Puesto que el protocolo es el conjunto de reglas y procedimientos que se tienen en cuenta en la ejecución de un plan concreto, en nuestro caso, la organización de un acto o evento empresarial que nos ayudará a transmitir una imagen institucional determinada. A través de estas reglas, por ejemplo, se establece cual es lugar que cada cual ocupa en la jerarquía, lugar establecido incluso por decreto o costumbre, se establecen los símbolos que tienen significados en la entidad en general y en el acontecimiento concreto en particular. No obstante, se estipula una jerarquía no sólo de personas también de espacios y tiempos.

El ceremonial, por su parte, comprende las formalidades de los actos y nos ayuda a crear una atmósfera solemne recurriendo a la simbología propia del evento, teniendo en cuenta su naturaleza.

No hay que olvidar que prácticamente desde que el mundo es mundo, el hombre ha recurrido a ceremonias o actos cuando la ocasión merecía comunicar a la población circunstancias de toda forma y color. En estos eventos, se recurría a un protocolo para establecer un orden con la finalidad de que los espectadores visualizaran lo que los anfitriones pretendían transmitir. Del mismo modo en estos actos, en muchas ocasiones, ya se convertía, de alguna manera, al público en protagonista y se le hacía partícipe del festejo.

En consecuencia, como se ha señalado, los actos que llevan a cabo las organizaciones vinculan a la institución y a sus públicos. Estos eventos, mediante una planificación y ejecución adecuadas, potencian la imagen pública $y$, si se desarrollan exitosamente, generan credibilidad, confianza y notoriedad. Además, cualquier detalle, por mínimo que sea puede marcar la diferencia y puede suponer que 
nuestro acto sea un éxito o todo un fracaso, con las consecuencias de imagen corporativa que esto supone.

Por todo lo estudiado en los apartados anteriores, para la consecución de lo previamente expuesto: una imagen y reputación positiva, necesitamos al protocolo y al ceremonial, como instrumento ordenador y cohesionador; una estrategia de relaciones públicas en la que basarnos así como a los medios de comunicación, que nos ayudan a difundir nuestros actos comunicativos y a transmitir quiénes somos y a quién nos dirigimos.

Por todo, los eventos, gracias a su fuerza comunicativa, tienen que formar parte de una estrategia de relaciones públicas para alcanzar, junto con los anteriores pilares, una reputación positiva. Por tanto, una buena gestión estratégica de la comunicación nos servirá para crear unas relaciones excelentes entre los públicos y redundarán en la imagen así como en el buen nombre de la organización.

\section{Referencias}

Campos, G. y César, J. (2010): "El necesario protocolo en la comunicación organizacional", en revista Icono 14, 2. Madrid, pp. 182-202.

Casal, O. (2013): "La Construcción de la Imagen Pública del poder a través del Protocolo y el ceremonial. Referencias históricas", en Historia y Comunicación Social, 18.

Fuente, C. (2007): Protocolo para actos. Técnicas de organización de actos. Madrid: Ediciones Protocolo.

Otero, M. T. (2000): Teoría y estructura del ceremonial y el protocolo. Sevilla: Mergablum. Edición y comunicación, S.L.

Otero, M.T (2001): Relaciones Públicas y Protocolo. Cinco años de Reflexiones (1996-2001). Monografía no 1. EIRP.CP: Sevilla.

Otero, M.T (2002b): "Identidad estatal y Constitución: Protocolo e imagen pública en el siglo XXI", en Revista Internacional de Investigación en Relaciones Publicas y Protocolo, No 1, pp. 71-86

Otero, M.T. (2002): "Las funciones del ceremonial y el protocolo en la reputación corporativa”, en Sphera Pública, 2. Murcia: Universidad de Murcia 
Otero, M.T. (2006): "Relaciones Públicas y gestión de públicos en eventos: los principios rectores del ceremonial y el protocolo", en Anàlisi 34, pp. 255-269

Portal de Relaciones Públicas. net (2014): "Imagen Corporativa". Recuperado el 1 de octubre de 2014 de http://www.rrppnet.com.ar/imagencorporativares.htm

RAE (2014): Diccionario de la Real Academia Española. Versión on line. Recuperado el 20 de septiembre de 2014 http://lema.rae.es/drae/?val=ceremonial

Rivadulla, D. (1996): "Precedencia y disposición de autoridades en actos universitarios". Recuperado el 1 de octubre de 2014 http://www.protocolouniversitario.ua.es/1encuentro/encuent ro $29 . \mathrm{pdf}$

Villafañe, J. (1996): Principios de la teoría general de la imagen. Madrid: Pirámide.

Villafañe, J. (1999): La gestión profesional de la imagen corporativa. Madrid: Ediciones Pirámide.

Villafañe, J. (2008): La buena reputación. Claves del valor intangible de las empresas. Madrid: Ediciones Pirámide

Weil, P. (1992): La comunicación global: comunicación institucionaly de gestión. Barcelona: Paidós. 



\title{
Las narcomantas: vía para producir noticias en un clima de violencia
}

\author{
Melitón Guevara Castillo \\ Cruz Alberto Martínez Cruz
}

Universidad Autónoma de Tamaulipas, México

\section{Resumen}

México y en especial el Estado de Tamaulipas vive un clima de violencia. La corrupción gubernamental permite un crecimiento y evolución del crimen organizado y del narcotráfico: las venganzas entre los distintos grupos; así como el combate que les plantea el ejército mexicano. En este contexto el narcotráfico se presenta como una empresa que desarrolla una construcción de noticias a través de las narcomantas: que aparecen junto al cuerpo de personas asesinadas para evidenciar poder sobre otros grupos; o en puentes peatonales para evidenciar la corrupción gubernamental o para establecer posturas ante grupos antagónicos. La postura gubernamental inicial fue negar evidente: la extorsión, el cobro de piso, los secuestros y las venganzas. Los medios de comunicación no publicaban nada, ignoraban los hechos y las narcomantas constituyen el medio de difusión que se hacen virales al ser incluidas en las redes sociales.

Palabras claves: Discurso, Narcotráfico, Narcomantas, corrupción, factores de poder. 


\section{El contexto}

¿Q UÉ ha sucedido con la política? ¿Con su ejercicio? ¿Qué papel Cesarrolla o desempeña el Estado en el México actual? Son preguntas que quizá, en este momento, no se tengan respuestas específicas. Se tiene que hacer, invariablemente, un esbozo para intentar explicar el hecho de que actualmente en México un grupo criminal sea capaz de paralizar 40 municipios de 4 estados, paralizar el tráfico vehicular, incendiar bancos y gasolineras y en la práctica rebasar al ejército ${ }^{4}$.

México, sus habitantes, de pronto tuvieron evidencias de la existencia de más y más grupos u organizaciones delincuenciales vinculados con el narcotráfico. Para darnos una idea de la magnitud del problema, en un momento dado la Procuraduría General de la Republica reconoció la existencia de 9 grupos o cárteles en México ${ }^{5}$ Cártel del Pacífico, Los Arellano Félix, La familia michoacana, Carrillo Fuentes, Beltrán Leyva, Los Zetas, El Cártel del Golfo, Los Caballeros Templarios y El Cártel Jalisco Nueva Generación.

Es tan grande el poderío económico de los cárteles que la revista Forbes incluyo en la lista de los hombres más ricos o poderosos del mundo a Joaquín "El Chapo" Guzmán ${ }^{6}$ líder del Cártel de Sinaloa. Obtiene ganancias por tres mil millones de dólares. El conocimiento de las cantidades de dinero que mueven estos grupos criminales nos lleva a darnos una idea del tipo de armas que pueden poseer. En ciertos momentos el gobierno mexicano ha reconocido que son superados en armamento por los grupos criminales.

\footnotetext{
${ }^{4}$ Cártel de Jalisco Nueva Generación. http://www.eluniversalmas.com.mx/columnas/2015/05/112469.php ${ }^{5}$ http://aristeguinoticias.com/1609/mexico/hay-9-carteles-del-narco-enmexico-controlan-43-pandillas-pgr/

${ }^{6} \mathrm{http}: / /$ www.milenio.com/policia/fortuna-Chapo-

Guzman 0 250175178.html
} 
En el caso específico de Tamaulipas la historia consigna la existencia, inicial cuando menos del Cártel del Golfo ${ }^{7}$, que nace en los años 30 como una organización dedicada al contrabando de licor de los Estados Unidos a México. Y en la década de los setenta el Cártel del Golfo incluye el narcotráfico en sus actividades y diversifica su repertorio de actividades criminales e incluye el narcotráfico; florece el negocio teniendo como destino final los Estados Unidos: y es la cuando se empieza a conocer la existencia de otros grupos u organizaciones dedicados a sembrar y traficar mariguana. Se identifica a México como un lugar de tránsito, es decir, solo un pasó de la droga hacia los Estados Unidos.

\section{Estado y violencia}

El estado está concebido como la expresión máxima de organización social de la sociedad. Su formación la da Hobbes, Locke, Rousseau y Montesquieu, entre otros. Rousseau explica las bases del gobierno de la mayoría; y Montesquieu la "división de poderes" (Chevalier, 1972). Como dice Bobbio (1994: 102): "Tradicionalmente el Estado es definido como el portador de la summa potestas (poder supremo); y el análisis del Estado se resuelve casi totalmente en el estudio de las diferentes potestades que le competen al soberano"

La definición clásica del Estado indica que está compuesto por un conjunto de ciudadanos, que asentados en un territorio, se dan un gobierno, unas leyes y tienen como fin el bien común. El materialismo histórico nos da otra definición: "conjunto de aparatos institucionales y normas destinadas a reglamentar el funcionamiento de la sociedad en su conjunto", y es conocida como la "estructura jurídico-política" de la sociedad, y forman parte de su superestructura" (Harnecker, 1980: 112).

El materialismo histórico nos explica que el Estado tiene una doble función: una función técnica-administrativa y una función política. Con la primera cumple su objetivo de "bienestar social", es decir,

\footnotetext{
${ }^{7}$ http://www.jornada.unam.mx/2003/03/15/046n1 soc.php?origen=socjus.html
} 
proveer a la sociedad de los bienes de consumo. La segunda se refiere a la "dominación política", que se divide en dos: la persuasiva y la de represión política (Harnecker, 1980: 116-117).

Con la función persuasiva el Estado busca legitimarse ante la sociedad; utiliza en esencia los medios de comunicación para difundir sus logros, sus proyectos y hacer saber a la gente que están trabajando correctamente. Si no hay protestas u objeciones, el gobierno se legitima. Por otra parte, si hay protestas e inconformidad, la función política asume el comportamiento "represor", porque es el dueño del ejercicio de la violencia. La historia muestra como el Estado, en momentos claves, ha sido represor. Los ferrocarrileros (1958), de los médicos (1964-1965) y del movimiento estudiantil de 1968.

\section{Estado y poderes facticos}

Al considerar al Estado como la organización social máxima se entiende que detenta un poder fuerte. En la sociedad se identifica la presencia de otras instituciones y organizaciones que en la práctica posen elementos para influir en el ejercicio del poder. Pablo González Casanova (1978) en los setenta describe:

"Los verdaderos factores del poder en México -como en muchos países hispanoamericanos- han sido y en ocasiones siguen siendo: a) los caudillos y caciques regionales y locales; b) el ejército; c) el clero; d) los latifundistas y los empresarios nacionales y extranjeros. Se trata, en todos los casos, de instituciones que han influido o influyen directamente en la decisión gubernamental...”.

En la siguiente década, Bobbio $^{8}$ (1992: 22) introdujo el concepto de "el poder invisible": "Puede ser que yo esté influido especialmente por lo que sucede en Italia, donde la presencia del poder invisible (mafia, camorra, logias masónicas atípicas, servicios secretos no controlados y protegidos de los subversivos que deberían controlar) es, permítanme la redundancia, extremadamente visible"

\footnotetext{
${ }^{8}$ Remite a Alan Wolfe y su libro The Limits of Legitimaacy", que utiliza el concepto de doble Estado o Estado invisible.
} 
En teoría es el Estado el que debe "gobernar" o dirigir a la sociedad. Los hechos, la realidad, nos indica que no sucede así: factores reales, gobierno invisible o poderes facticos, son ya parte de una realidad. En este sentido, Aceves González (2013) hace una revisión conceptual para precisar lo que se entiende por "poderes facticos"; distingue entre grupos de presión, grupos de interés y los poderes o factores facticos. Su punto de partida y fuente de conclusiones es la definición que da la Real Academia Española:

"En su extrema simplicidad, esta definición establece de manera puntual dos elementos básicos que caracterizan aquello que podríamos identificar como poder fáctico. Uno, que se trata de corporaciones que tienen la facultad o la capacidad para realizar acciones conforme a sus intereses particulares, y dos, que dichas acciones se realizan por fuera del marco jurídico institucional, es decir que se encuentran revestidas de un carácter extralegal. Asumida esta definición, sea de manera explícita o implícita, el debate se ha centrado en la identificación de los actores o instituciones que pueden caracterizarse como tales" (Aceves, 2013: 271).

Para el caso mexicano González Casanova (1978: 45-46) ya dio una lista que hoy ya no responde a una realidad; los poderes facticos han evolucionado. Caciques regionales y latifundistas han desaparecido y un nuevo poder ha emergido: el crimen organizado, manifiesto en los cárteles del narcotráfico que han sido identificados y ubicados por las autoridades policiacas.

Triay Montiel (2012) al abordar "el poder y las políticas de muerte en los narcomensajes" introduce el concepto de "violencia organizada", y recupera la visión de la estructura del narcotráfico como un "actor

\footnotetext{
${ }^{9}$ Los cárteles o grupos del narcotráfico han mostrado su capacidad para crear violencia organizada; lo han realizado en ciudades como Monterrey, Tampico, Altamira, Reynosa y el más significativo fue en Guadalajara; arman bloqueos, incendian vehículos, secuestran otros, asaltan bancos, incendias gasolineras y en un caso, el de Guadalajara, desquiciaron autopistas y más de 40 municipios de 4 estados.
} 
semejante a un segundo Estado" (Segato, 2005: 265-285). Triay describe la estructura del narcotráfico "como un ente que cobra vida mas allá de una noción incorpórea, cuya imagen es la de un sujeto fuera de los márgenes de la ley y, por lo tanto, de nuestra vida social. Es una estructura que rebasa lo comercial y que va más allá de ser sólo un productor y reproductor de la violencia” (Triay, 2012: 11).

Gramsci demuestra que la supremacía de un grupo social sobre otros se manifiesta de dos maneras: como dominio o coacción; que nacen de los recursos de poder que disponen y que se demuestran a través de la dominación, la autoridad o la dirección, y de todas ellas al mismo tiempo (Citado por Giménez, 1983: 20). En este caso, se hace notar que "La violencia es el primer recurso del narcotráfico (1) por el negocio en sí; (2) por el dominio en un sentido de territorialidad y en contra de las leyes y sus ejecutores; y (3) por la obediencia que exige hacia otras fronteras" (Triay, 2012: 15).

La violencia que se ha desatado en gran parte del territorio nacional, y en Tamaulipas, tiene dos vertientes: 1) La lucha entre los distintos cárteles por obtener la supremacía en su actividad ilícita; y, 2) La guerra que les declaro el gobierno de Felipe Calderón (2007-2012) después de notar la creciente violencia, el incremento de secuestros y extorsión.

\section{Estado y discurso}

Con la idea de que el Estado es un instrumento de un grupo o clase social para extender su dominio sobre otros grupos sociales, aparecen conceptos como el de hegemonía y el de dominación. Así es como se explica que las elites gobernantes impongan a los gobernados una cultura, un sistema de ideas y creencias ${ }^{10}$.

Foucault en "El orden del discurso" describe como quien gobierna usa determinadas palabras, prohíbe otras; y que las palabras que se pronuncian adquieren significado según quien las diga, la ciencia que profese y el lugar donde este ejerza su actividad. Y será Foucault el

\footnotetext{
${ }^{10}$ Aparatos ideológicos que, según Althuseer, son la escuela, la iglesia, las costumbres y creencias, los medios de comunicación.
} 
que diga que estamos sometidos a la verdad, en el sentido de que la verdad hace ley, elabora el discurso verdadero que decide, trasmite y empuja efectos de poder. Foucault (1995) señala que somos juzgados, condenados, clasificados, obligados a competir, destinados a vivir de un cierto modo o a morir en función de discursos verdaderos que conllevan efectos específicos de poder.

¿Qué es el discurso? Giménez (2008) explica que la palabra proviene del latín discurrere que significa fluir o correr, y recurre a Greimas (1979: 102) para definirla como: "un proceso semiótico que se manifiesta en forma de prácticas simbólicas (lingüísticas o no lingǘsticas)". El discurso es entendido como un "segmento de la cadena hablada o escrita provista de sentido, y por ello capaz de cumplir una función comunicativa entre emisor y receptor, ya que es lo que aquél produce y lo que éste escucha" (Beristain, 1985: 185186).

Para Jager (2003: 63) el discurso debe ser considerado "como fluir del conocimiento $-\mathrm{y}$ de todo el conocimiento societal acumulado- a lo largo de toda la historia, fluir que determina los hechos individuales o colectivos, así como la acción formativa que moldea la sociedad y que, de este modo, ejerce el poder..." Dicho en otras palabras: "el discurso no puede ser reducido a una mera visión distorsionada de la realidad o a una ideología innecesariamente falsa, por el contrario, el discurso representa en sí misma una realidad propia, alimentada además del pasado, y de los discursos e interpretaciones coetáneos" (Paniagua, 2012: 195).

En palabras de Giménez (2008: 14) el discurso se concibe como "una forma de acción -o mejor, de interacción- inscrita en marcos institucionales (y coyunturales) donde existen posiciones dominantes y posiciones dominadas, es decir, una correlación de fuerzas...". Entender esta realidad obliga recurrir a la comprensión del poder.

El poder se inscribe en la relación de fuerzas que se instaura entre sujetos (individuales o colectivos) desiguales por su relación y por su potencial de recursos (económicos, militares, de información, etc.). Y en virtud de esta relación de fuerzas, el sujeto o los sujetos 
dominantes pueden estructurar u orientar el campo de acción de los que son dominados (Giménez, 2008: 40).

El escenario para el análisis del discurso en un clima de violencia, de inseguridad, de choques, bloqueos y narcomantas, involucra cuando menos a tres actores participantes en una interacción de dominantedominado: 1) El Estado y sus actores o instancias de los gobiernos federal, estatal o municipal; 2) la sociedad civil; y 3) las facciones criminales que desarrollan estrategias para alcanzar sus propósitos ya sea legitimar, dominar o exigir" (Paniagua, 2012: 194). En su texto "Para los que no creyeron... y para los que siguen sin creer...", Paniagua (2012: 198) hace una clasificación de las modalidades o variantes del discurso de los tres participantes:

"El uso del discurso se presenta en 5 direcciones en las que interactúan los participantes involucrados: 1.- del crimen organizado al Estado; 2.- del crimen organizado a la sociedad; 3.- entre células del crimen organizado; 4.- el discurso en forma de declaraciones políticas; 5.- el discurso en forma de declaraciones de miembros de la sociedad" (Paniagua, 2012: 198).

Paniagua describe los hechos de Cd. Juárez, Chihuahua; que no son diferentes a los que se están viviendo en Tamaulipas. Sin embargo, en el caso de Tamaulipas hay un ingrediente más: la interacción, o vinculación, que construyen los grupos delincuenciales en procesos entretenimiento o de apoyos sociales ${ }^{11}$ en abierto reto a la autoridad.

\section{Discurso de la inseguridad: Las narcomantas}

¿Qué sucedió en Tamaulipas? ¿Por qué, si ya había experiencias, el fenómeno no se combatió en su origen? ¿A quién culpar? ¿A las autoridades federales, a las estatales o las municipales? ¿Qué tanto

\footnotetext{
${ }^{11}$ Con la complacencia de autoridades organizaban fiestas el "Día de la madre", el "Día del niño" y en navidad; y momentos de desastre naturales, un ciclón o lluvias torrenciales que inundan núcleos urbanos, repartían despensas y hasta tinacos para el agua.
} 
determino la evolución de los hechos como una derivación de la corrupción gubernamental?

\subsection{Discurso inicial: Negación de la crisis}

Las narcomantas muestran la evolución de los grupos delincuenciales en su forma de operar: contrabandistas antes de los setentas; luego narcotraficantes y luego amplían sus operaciones al secuestro, secuestro exprés, cobro de cuotas de piso, adueñarse de bienes inmuebles, robo de vehículos. En el 2010 se hace visible para la sociedad los conflictos de unos y otros grupos antagónicos.

Ante esta situación el gobierno del estado adopta una postura de negación: "no pasa nada", declara el gobernador Eugenio Hernández Flores (El Diario, 26 de febrero 2010). Esta postura es llevada mas allá por el PRI que propone a los distintos partidos políticos, no politizar el tema de la seguridad pública (El Diario, 25 de marzo 2010); propuesta que solo el PAN rechaza. El clima de violencia es tan evidente y alcanza su clímax con el asesinato del candidato del PRI a gobernador, a tan solo 10 días de las elecciones (El Diario, 27 de junio 2010).

Siguiendo el discurso gubernamental los medios de comunicación, salvo dos o tres excepciones, ocultan la información sobre la creciente violencia y actos ilícitos del crimen organizado. La postura gubernamental es abonada por acciones que se entiende, proviene de los grupos de la delincuencia: como hacer explotar coches bomba frente a edificios en los que operan ciertos medios informativos, como Televisa ${ }^{12} \mathrm{Cd}$. Victoria, El Expreso ${ }^{13}$ y El Mañana de Nuevo Laredo.

\subsection{Las narcomantas}

Al hacer una revisión de las narcomantas utilizadas en el Estado de Tamaulipas se pueden identificar tres grupos en base a su contenido y

\footnotetext{
${ }^{12}$ http://www.eluniversal.com.mx/notas/704561.html

${ }^{13}$ http://mexico.cnn.com/nacional/2012/03/20/un-coche-bomba-estalla-alas-afueras-de-un-diario-en-tamaulipas
} 
emisor. Cada uno de estos tipos presenta información que tiene un propósito claro: señalar que el emisor es poderoso; que en ese proceso de lucha, la corrupción gubernamental es parte activa del mismo; y que, en última instancia, el emisor no busca afectar a la sociedad en general.

Intimidación a grupos contrarios. El objetivo es dominar una plaza. Cada grupo para ampliar su territorio de dominio y explotación, se va adueñando de una ciudad: en la frontera, Nuevo Laredo, Reynosa, Rio Bravo y Matamoros; en el Centro de la entidad, la capital Victoria y los lugares aledaños; y en el sur, la zona conurbada de Tampico, Madero y Altamira.

Los elementos que evidencian la guerra del Cártel del Golfo y Los Zetas son las vendettas o ejecuciones que van realizando. En Victoria apareció un hombre muerto, aproximadamente de 30 años, con tres balazos en su cabeza. Estaba esposado y tenía una venda en los ojos. Sobre su cuerpo estaba una cartulina con el siguiente texto:

"Esto es lo que les pasa a los cu... que traicionaron a la compañía y que se quieran pasar de ver... todos esos cab... que anden de panochones y dedos por que los vamos a quebrar atentamente Z"14.

La lucha de cárteles por una plaza rebasa los límites de la entidad. La existencia de 9 cárteles con un afán de ampliar su territorio provoca le declare la guerra a otros grupos. Tal como sucede con un cártel Nueva Generación de Jalisco:

"A todos los mugrosos de qué sirve tener mandos si cuando los agarran lloran como 42 y ustedes pendejos porqué trabajar si no les pagan. Cd. Victoria es de ustedes, Demon Dandy. Hasta cuándo seguir de agachones por los culos de Nuevo Laredo. Esto apenas comienza y aquí andamos pinches putos" $" 15$

\footnotetext{
${ }^{14}$ http: $/ /$ www.hoytamaulipas.net $/$ ?v1 $=$ notas $\& v 2=65419 \&$ tit $=$ Encuentran mue rto con mensaje

${ }^{15} \mathrm{http}: / /$ sentido-comun.com.mx/2015/03/aparece-narcomanta-en-cdvictoria/
} 
Los grupos o cárteles del narcotráfico funcionan como una empresa; sus líderes realizan acuerdos y transacciones; y hasta realizan "cumbres" para repartirse las plazas o hacer reacomodos de plazas (Hernández, 2010). En Nuevo Laredo, la lucha por la plaza fue, ha sido, cruenta; los acuerdos y desacuerdos, se hacen notar con una manta, en donde se identifican "renegados", ya inconformes por no cumplir con los tratos.

“Te pasas la verga pinche rama tú y El Joto de Mayito. Ése no era el trato. En ti no se puede confiar. Eres igual que Los Treviños de traidores. Att. CDG y Z Renegados"16

La lucha entre cárteles en Nuevo Laredo adquiere dimensiones extraordinarias los inician acusaciones de corrupción y hasta de participación de autoridades. El caso que cimbro a la sociedad, fue la amenaza en contra de Benjamín Galván ${ }^{17}$. Aparece una narcomanta en la cual se coloca su imagen, fotomontaje: es un mensaje de El Chapo Guzmán en el cual reclama al alcalde que niegue la presencia del Cártel de Sinaloa en la ciudad, de que declaren que no pasa nada. El contexto de la narcomanta es la aparición de 7 muertos y luego 14, estos últimos decapitados; los cuerpos estaban en bolsas negras al interior de un coche; luego aparecieron las cabezas en hieleras:

"Quieren credibilidad de que estoy operando aquí, díganme como... ¿con cabezas de funcionarios Zetas, o sea ustedes?", "Señor Presidente, como nos quiere dar un dulcito, al salir usted declarando que aquí no pasa nada y que todo está bien, siga con lo mismo y le aseguro que van a seguir rodando cabezas",

\footnotetext{
${ }^{16}$ http://www.puronarco.com/2013/09/cdg-y-zetas-renegados-colocannarcomantas-en-nuevo-laredo/

${ }^{17}$ Ya en condición de ex alcalde fue secuestrado en Nuevo Laredo. Su cuerpo fue encontrado en el municipio de Garza García (estado vecino) y en el Servicio Médico Forense del Hospital Universitario fue identificado.
} 
"Sigan haciéndole caso al Z40 para decir y negar que ya operamos en Nuevo Laredo, solo para Lazcano no regañe a este analfabeta y lavacarros".

"Y tú, director de Seguridad Pública estás puesto plenamente por el Z 40, quien es tu compadre, sigue declarando que no anda mi personal aquí en Nuevo Laredo. O tú, MP, sigue señalando que los descuartizados eran albañiles, comerciantes, migrantes o simples y modestos trabajadores o sigan negando mi presencia aquí en Nuevo Laredo y van a seguir sus cabezas".

"Yo no mato inocentes para presentar trabajo como tú estás acostumbrado Z 40, todo muerto en Nuevo Laredo es pura escoria o sea puro Z!!!!”... Atte: Tu padre Joaquín, El Chapo Guzmán!"’18.

Un día la sociedad se sorprendió. Aparecieron mantas en donde se anuncia una tregua; donde el Cártel del Golfo y Los Zetas, destacando que quienes generaron la violencia, han sido detenidos o ejecutados; y que ahora, los nuevos líderes, están convencidos de que ese no es el camino correcto.

\footnotetext{
${ }^{18}$ http://blogs.periodistadigital.com/hermosillo.php/2012/05/08/temiblemensaje-del-chapo-guzman-al-alca
} 


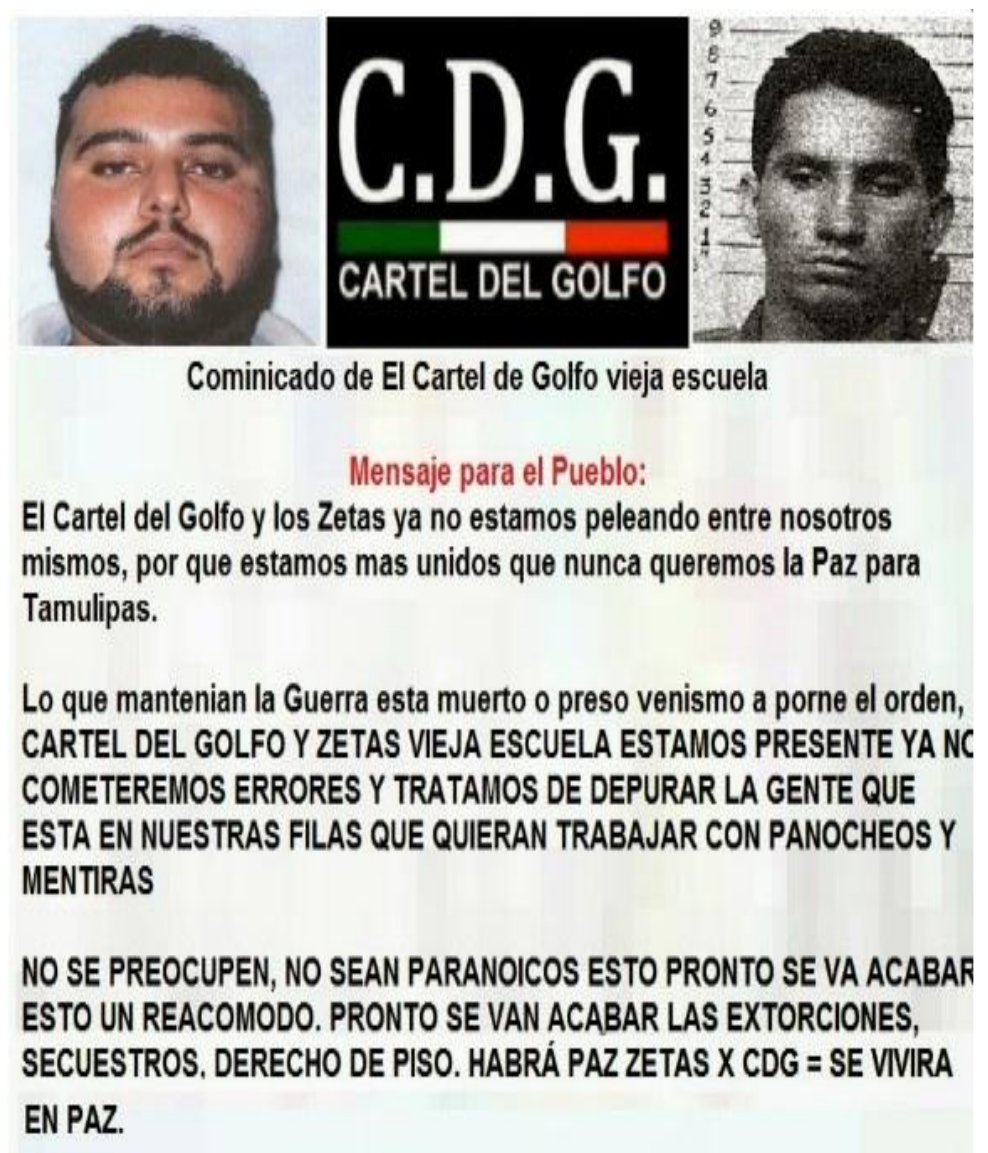

\section{LA NUEVA ALIANZA DE LA PAZ CARTEL DEL GOLFO Y ZETAS}

ATT: COMANDANTE R1 LOS ROJOS CDG Y COMANDANTE KELIN ZETAS UNIDOS

Fuente: http://www.sdpnoticias.com/local/tamaulipas/2014/11/11/carteldel-golfo-y-los-zetas-anuncian-alianza

Los mensajes de las narcomantas cumplieron su objetivo: evidenciar que en Tamaulipas el Estado y sus autoridades se vieron incapaces de hacer valer el Estado de Derecho. Y las consecuencias de crímenes, de extorsiones, de secuestros son parte de la estadística de la Seguridad Pública.

Denunciar corrupción gubernamental. La percepción de la corrupción en México es enorme y es difícil negarla ${ }^{19}$. En Nuevo Laredo y en Reynosa, ciudades fronterizas (con Estados Unidos) aparecieron mantas. En ellas, con la imagen de Felipe Calderón (Presidente de la Republica) se denuncia que hay contubernio del Gobierno Federal y

\footnotetext{
${ }^{19}$ En Los infiltrados (Aponte, David: 2012) se describen hechos y operaciones de corrupción gubernamental y policiaca ligados a los distintos cárteles del narcotráfico. Véase también: Los señores del narco (Hernández, 2001)
} 
de los militares con grupos del narcotráfico, que brindan protección a Joaquín Guzmán Loera (El Chapo), Oscar Valencia, Ignacio Coronel (El Coronel), Ismael Zambada (El Mayo), La Familia y a Martín Cordero Luqueño. Las mantas dan los nombres de los militares coludidos: General regional, Marco Covarrubias Aguilar; General de División, Roberto Miranda Sánchez. Todos los militares a la ordenes de: Joaquín Guzmán Loera (El Chapo), Oscar Valencia, Ignacio Coronel, Ismael Zambada, y a La Familia ${ }^{20}$.

Vinculación con la sociedad. Esta es una variante en el comportamiento de los grupos del narcotráfico: desarrollaron un proceso de vinculación con la sociedad. En las comunidades rurales se conoció que los grupos criminales repartían despensas e incluso, en Mainero (municipio ubicado a $100 \mathrm{~km}$. de la capital del Estado) los campesinos llegaron a recibir tinacos (recipientes para almacenar agua) con una $Z$ inscrita en un costado ${ }^{21}$.

Siempre se conoció que un conocido o líder narcotraficante brindaba apoyo. Enviaba piñatas, dulces y regalos a las iglesias. Sin embargo fue más patente en la capital del Estado: Victoria. Se anunciaba en medios de comunicación fiestas "al niño", "a la madre" o por la navidad. Todavía el año pasado, en el 2014, por medio de volantes el grupo de "Los Zetas", convocaron a festejar el Día del Niño en la capital. Decía la invitación: "Invitamos a todos los niños de Victoria a la gran fiesta infantil del día 30 de abril en punto de las cinco de la tarde en la Disco Victoria Música Hall en honor a todos nuestros hijos" $^{22}$. En los volantes se hace notar que habrá sorpresas como rifas, presentaciones de payasos y de muñequitas, animadoras de televisión regia, y juegos mecánicos en el estacionamiento del lugar.

\footnotetext{
${ }^{20}$ http://www.zocalo.com.mx/seccion/articulo/aparecen-mas-narcomantasen-reynosa

21 Para este tipo de acciones el grupo narcotraficante se proveía asaltando camiones en la carretera. Desparecían tráileres cargados de frutas, de alimentos embotellados, embolsados, etc.

${ }^{22}$ Los Zetas organizan evento para festejar el Día del Niño en Ciudad Victoria, Tamaulipas - economiahoy.mx http://www.economiahoy.mx/nacional-eAm$\mathrm{mx} /$ noticias/5729891/04/14/Los-Zetas-organizan-evento-para-festejar-el-Diadel-Nino-en-Ciudad-Victoria-Tamaulipas.html\#Kku8DFdFsmY1jDKK
} 
La invitación estaba firmada por la Asociación de Jóvenes Victorenses, membrete de Los Zetas.

El Cártel del Golfo también hizo lo mismo 6 de enero de 2014: repartió "roscas de Reyes" ${ }^{23}$. Hicieron circular un vídeo en YouTube $^{24}$, de 2.48 minutos. En el video muestra como miembros del grupo delictivo hacen entrega de roscas en casas, escuelas, hospitales y asilos. Se hace a la vista de todos: de la población, de las autoridades. Hasta que un día el ejército bloqueo los accesos viales al lugar y no permitió la entrada de las familias que acudían a la invitación.

\section{Conclusiones}

México vive un proceso similar al de Colombia: un contexto de violencia. El poder, la influencia, la capacidad de los cárteles del narcotráfico creció y se hizo evidente, que el Estado asumió de manera frontal combatirlos. Se desencadeno una espiral de violencia, crímenes y desaparecidos.

Los distintos cárteles, con dominio en territorios específicos, han mostrado capacidad de respuesta. Y una forma de hacer su guerra son las marcomantas: cuyos mensajes van dirigidos a los grupos contrarios, al gobierno y a la sociedad. Una revisión de marcomantas en Tamaulipas nos ofrece conclusiones inevitables:

a) El Estado o gobierno, sus gobernantes y autoridades han sido incapaces de frenar la violencia ocasionada por los enfrentamientos entre los distintos grupos del crimen organizados; y por los enfrentamientos del crimen organizado con el gobierno (militares, marina y policías federales).

b) El discurso gubernamental que negaba y ocultaba los hechos fue una estrategia fallida. Los hechos, aunque no se difundan,

\footnotetext{
${ }^{23} \mathrm{http:} / /$ www.proceso.com.mx/?p=361772

${ }^{24}$ http://www.redpolitica.mx/estados/video-presuntos-narcos-reparten-roscade-reyes-en-tamaulipas- 0
} 
no pueden ser ocultados. Las redes sociales socializan la información.

c) El narcotráfico, o crimen organizado, se muestra como una empresa: con objetivos, con estrategia y táctica, para evidenciar poder, fuerza y energía.

d) Tanto el Cártel del Golfo, como Los Zetas, buscaron tener el apoyo de la sociedad; 1) Con las narcomantas que denuncian la corrupción y colusión de militares y policías con los grupos contrarios; 2) acciones en beneficio de la sociedad, como las fiestas para festejar el Día del Niño, el Día de la Madre y la entrega despensas y artículos del hogar a campesinos y a habitantes de colonias marginadas

\section{Referencias}

Beristáin, Helena (1985). Diccionario de retórica y poética. México: Porrúa. Bobbio, Norberto (1994). Estado, gobierno y sociedad. México: FCE.

Bobbio, Norberto (1992). El futuro de la democracia. México: FCE.

González Casanova, Pablo (1978). La democracia en México. México: Ediciones Era, serie popular.

Greimas, A. J. (1979). Sémiotique. París: Hachette-Université.

Aceves González, Francisco (2013). "Poderes facticos, comunicación y gobernabilidad: un acercamiento conceptual". Revista Mexicana de Ciencias Politicas y Sociales. No. 217, enero-abril de 2013. México: UNAM.

Hernández García, Anabel (2011). Los señores del narco. México: Ediciones Grijalbo.

Paniagua Vázquez, Abraham (2012). "Para los que no creyeron... y para los que siguen sin creer...”. Prisma social. No. 8. Revista de Ciencias Sociales. España.

Triay Montiel, Eva Natalia (2012). "México: el poder y las políticas de muerte en los narcomensajes". Versión No. 29, mayo 2012. México: UAM. 


\section{El color, la forma: su influencia en el empaquetado y en la imagen corporativa}

Juan Luis Gamarra Sánchez

Universidad de Granada

Marta González-Peláez

Universidad de Vigo

\section{Resumen}

En la imagen corporativa y de los productos el color y la forma del empaquetado son muy importantes en la comunicación del producto hacia los públicos objetivos destinatarios: los consumidores o clientes.

La comunicación a través del lenguaje publicitario proyecta en el consumidor el deseo de compra y de elección previa en función de los parámetros que el mensaje o eslogan, la marca y el conjunto de los elementos psicológicos y neurofisiológicos creen en la mente de los receptores.

El diseño del envoltorio debe de cumplir una serie de requisitos como son la utilidad, la creatividad y la sostenibilidad. En la cultura oriental el envoltorio o empaquetado (packaging) tiene mucha importancia y la nuestra cada vez más ha ido ganando terreno y cualquier producto aunque sea de calidad mediocre debe de tener un envoltorio exquisito y un color atractivo de tal forma que seduzca a nuestros públicos objetivos. Las formas y los colores producen sensaciones agradables: tranquilidad, excitación, ingenuidad, paz entre otras. 
Palabras clave: Comunicación, color, empaquetado, público, emoción

\section{Introducción}

— L color y la forma se constituyen y se procesan en el cerebro de la misma forma que los significados de las palabras. Sin esos procesos neuronales no seríamos capaces de comprender los colores y las formas de los objetos. Es un tipo de lenguaje y de comunicación distinto al hablado.

El color es un elemento que está presente y es muy importante tanto en la imagen corporativa como en la personal.

Los colores ejercen una gran influencia, comunican y proyectan emociones, sensaciones e impactos estéticos y visuales agradables. Influyen en nuestro estado de ánimo y tienen un impacto positivo fundamentalmente en nuestra capacidad de concentración y aprendizaje.

En la elección de los colores para elaborar la imagen corporativa hay que tener en cuenta algunos factores como la combinación de los colores y lo que el color puede aportar en la elección de uno u otro producto. Las connotaciones culturales y sociales son muy importantes; cada color tiene un significado y comunica de forma diferente en función del contexto cultural. El color es tan importante como el imagotipo o logotipo, así como la forma del envoltorio o packaging del producto y hay que intentar ser fiel a la cultura y a la política empresarial y organizacional así como al estilo personal de cada cual.

Cuando decidimos elaborar la marca corporativa también contemplamos que color es el más aconsejable para las marcas y el producto. Las empresas saben que para vender ya sean servicios, bienes de consumo o productos, además de las propias estrategias de comunicación, la persuasión, el color y el envoltorio son lo más importante para la fidelización de los públicos objetivos y de los clientes. 
La forma del empaquetado, del envoltorio o packaging del producto es muy importante a la hora de ubicar y lanzar un producto, servicio o bien de consumo en el mercado. Empaquetado junto al color estudiado y por tanto adecuado es parte del éxito de penetración en los públicos y en el mercado.

Un ochenta y cinco por ciento del público objetivo y del potencial cliente a la hora de la decisión de compra observa el color como el elemento determinante de la culminación de la adquisición. Por eso es muy importante tener en cuenta que psicológicamente los seres humanos nos movemos por emociones y por reproducción de modelos y los colores y las formas nos transmiten emociones y sensaciones.

La colorimetría es la ciencia que ayuda a diseñar y aumenta el reconocimiento en el consumidor.

\section{El color: lenguaje y comunicación}

Es un tipo de lenguaje y de comunicación distinto al hablado. El color es un elemento que está presente y es muy importante tanto en la imagen corporativa como personal.

La percepción del color es un proceso neurofisiológico complejo, se asocia al acto físico de la visión o de la incidencia de la luz en los cuerpos provocando sensaciones en las personas y también en algunos animales.

El color y la forma se constituyen de la misma forma que se crean, memorizan y almacenan los significados de las palabras en el cerebro. El proceso es muy similar.

Tendremos que remontarnos a la época de Aristóteles (384 - 322 a. C), quien primero habló y definió que todos los colores se crean partiendo de cuatro colores. Los colores básicos para él eran: el color de la tierra, el del fuego, el del agua y el del cielo. 
Avanzando un poco más en la historia de la humanidad llegamos a un momento esplendoroso, a la época del Renacimiento dónde el gran genio Leonardo Da Vinci (1452-1519) que adelantó y profundizó un poco más en el estudio cromático definiendo una escala de colores básicos: el blanco como el tono principal pues permite recibir a todos los demás colores; a continuación el amarillo como el de la tierra, siguiendo con la tonalidad verde para el agua, el azul para el cielo, el rojo para el fuego y la sangre y el negro para la oscuridad.

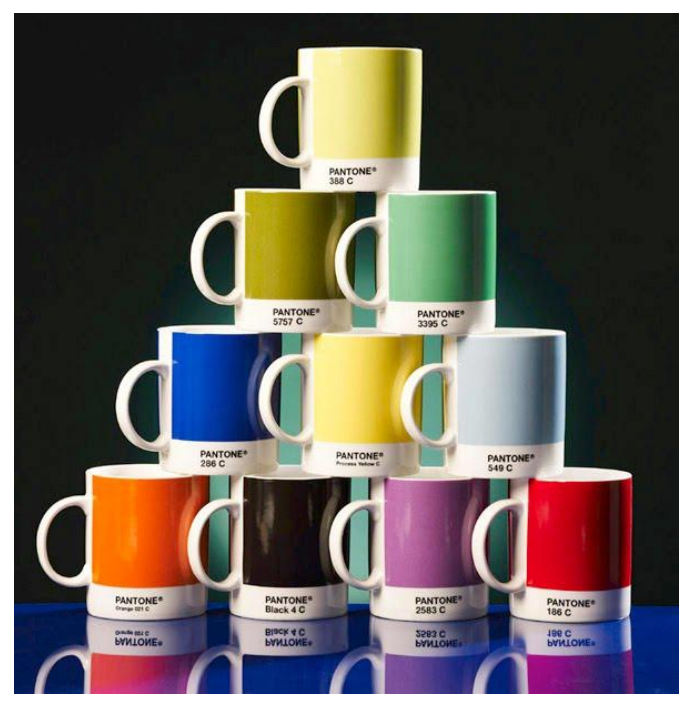

Fuente: http://illikeit.blogspot.com.es/

Mezclando estos colores se obtendrán todos los demás colores y toda la gama cromática que se irá ampliando con la utilización de las mezclas. Y siguiendo nuestro recorrido llegamos a la época de Isaac Newton (1642-1727) quien estableció un principio que se ha aceptado y respetado hasta el día de hoy: la luz es color. En 1665, Newton descubrió que la luz del sol al pasar a través de un prisma se dividía en varios colores conformando un espectro.

El color, según Isaac Newton, es una sensación que se produce en función de la estimulación nerviosa del ojo, causada por una longitud de onda luminosa. El ojo humano interpreta colores distintos dependiendo de la distancia a los que los perciba y la emisión de onda. 
Los colores nos producen sensaciones, emociones, sentimientos, diferentes estados de ánimo. Los colores son mensajes con mucha información, nos expresan valores, situaciones, pero no existen más allá de nuestra percepción visual.

Isaac Newton consiguió la descomposición de la luz en los colores del espectro. Esos colores son básicamente el azul violáceo, el azul celeste, el verde, el amarillo, el rojo anaranjado y el púrpura. Este fenómeno lo podemos observar cuando la luz se refracta en el borde de un cristal. También cuando llueve y hace sol, las gotas de agua de lluvia producen el mismo efecto que el prisma de Newton y descomponen la luz produciendo los colores del arco iris.

Con esta observación llegó a la siguiente conclusión en su estudio: todos los cuerpos opacos al ser iluminados reflejan todos o parte de los componentes de la luz que reciben.

En los cien últimos años se ha avanzado muchísimo en el mundo de los colores. En la prehistoria utilizaban colores pero solo disponían del tono de la tierra, el de la sangre y el de la ceniza hoy en día podemos hablar de gamas cromáticas inmensas, casi infinitas. A la hora de escoger un objeto además de por su naturaleza (producto en sî), la forma y el color, son determinantes en la elección final de compra del consumidor o cliente. Tanto antropológicamente como psicológica y sociológicamente, el color tiene significados diferentes en función de su contexto y de la cultura. Las tonalidades tienen significados y valores distintos en base a los parámetros mencionados.

Los colores así como las formas y las palabras evocan ideas y conceptos. El azul claro nos puede retrotraer a un recuerdo de infancia cuando observábamos el vuelo de la cometa en la inmensidad del cielo azul. También nos recuerda el mar, las vacaciones y otras vivencias que nos retrotraen a momentos positivos que nos resultan agradables permanecen en el cerebro y los rememoramos espontáneamente cuando observamos un producto ya sea un artículo de vestir, para decoración, de comida o de cualquier otro tipo. 
Dependiendo de muchos y diferentes factores el uso de los colores, así como el efecto y su significado son distintos. Y esa utilidad es importantísima para los publicistas a la hora de diseñar el envoltorio, ya sea este un a caja una bolsa o un simple papel, el envase, la marca y el logotipo.

El color forma parte del lenguaje no hablado y comunica y mucho, a veces más que una palabra o un gesto. Pues si nosotros observamos una fotografía - con un fondo neutro blanco- en ella aparece una persona que viste un traje de color beige clarito y unos zapatos de piel color miel, automática y espontáneamente nuestro cerebro procesa que se trata de una persona que vive en un país tropical donde hace calor y el color beige es relajante y aunque no sea el tono que filtre más los rayos solares, pero si es agradable a la vista además de ser muy armónico con el entorno.

Podemos también interpretar como una estampa de verano simplemente o alguien a quien le guste vestir de color beige o que ha escogido ese color porque está de moda y de actualidad.

Asimismo la meteorología y la ubicación geográfica marcan el uso del color en comunicación y en todos los ámbitos de la vida humana. Existen unos colores estacionales que independientemente de las modas los utilizamos ya que los tenemos aprendidos e interiorizados y almacenados en el inconsciente de nuestro cerebro (por una cuestión cultural) que afloran de forma espontánea en ocasiones.

Los tonos cromáticos brillantes son más propios del verano ya que por efecto de la luz (como hemos explicado al principio de este artículo), brillan más, el sol luce más horas y su incidencia es mayor. Además de positivos, dan alegría y proyectan optimismo. Colores de otoño simbolizados por la armonía cromática de los amarillos ocres y el invierno representado por el blanco de la nieve y la baja intensidad de la luz solar y el color del cielo con los árboles sin hojas.

La globalización, Internet, el mundo líquido y la velocidad de la información entre países, ha "roto" barreras culturales, ha eliminado las fronteras $\mathrm{y}$ ha hecho permeables a las culturas entre sí, 
intercambiándose formas usos y costumbres, incluidos por supuesto los colores.

Antropológicamente hablando, los colores no significan lo mismo en todas las culturas e incluso en algunos países existen colores para los días de la semana como es el caso de Tailandia.

El color rojo por ejemplo en nuestra cultura es el tono de la pasión, psicológicamente lo definen como el de la asertividad; del amor, el sexy, el de la fuerza, también es la tonalidad que nos indica peligro y nos advierte (señales de tráfico) y el de la reivindicación entre otras connotaciones (marcas de sindicatos). En cambio en los Estados Unidos de Norteamérica es además el color de la Navidad, de Papa Noel (familia, amistad) y de San Valentín (amor). En China es el color de la buena suerte y la celebración, vitalidad, felicidad, color en las bodas, el de la buena fortuna y la prosperidad. En Tailandia es el color del domingo.

En Japón simboliza la vida. En Sudáfrica es el color del luto. En Rusia se asocia con los bolcheviques y el comunismo y para la cultura hebrea, sacrificio y pecado.

El uso de este color ayuda a superar la depresión y aumenta la efervescencia y regula el metabolismo; asimismo simboliza la pasión y el deseo sensual y sexual. Aunque el exceso puede producir estado de ansiedad y una cierta agitación.

\section{El color rosa}

Es el tono del cariño, de la ingenuidad, de la felicidad, la alegría, el amor maternal y la protección. También nos aleja de la soledad y es el que se asocia a las personas sensibles. En Tailandia es el color del martes.

Su uso es útil para las terapias de problemas mentales.

\section{E1 color negro}

En nuestra cultura es el color del luto, la tonalidad de la noche, es el tono sobrio y uno de los considerados más elegantes en el vestir. En 
China es el color de los hombres jóvenes. En Japón es el color que se asocia con lo femenino y lo misterioso.

Su uso aporta paz y crea silencio.

\section{El color azul}

En nuestra cultura es el color masculino por excelencia, también el de la armonía, de la responsabilidad el de la sobriedad, la seguridad y así como el de la seriedad sobe todo en los negocios. Color del liberalismo. El color de la realeza. En China se asocia a la inmortalidad y a la pornografía.

Su uso tranquiliza mentalmente y disipa los temores.

\section{El color amarillo}

Es el tono de la innovación, de la inteligencia. También es la tonalidad de la precaución ante un aviso de peligro. En China es el tono considerado imperial, sagrado y masculino. Su uso ayuda a la estimulación mental. Aunque el uso excesivo de este color puede producir agotamiento.

\section{El color blanco}

Es la tonalidad de la pureza, de la inocencia, del optimismo, de la limpieza y de la asepsia, así como de las novias. En China y Japón es el color del luto así como en los países árabes.

Su uso purifica la mente a los más altos niveles y produce equilibrio mental.

Los colores también transmiten sensaciones de frío y de calor. Existe por ello una clasificación de colores fríos y cálidos.

Los colores así mismo pueden ser chillones o discretos; cultos o incultos; caros o baratos y alegres o serios. O también connotativos, denotativos, fantasiosos, icónicos y saturados.

Estas son descripciones aprendidas en nuestro entorno familiar y ambiental. 


\subsection{Color denotativo y el color connotativo El color connotativo}

La connotación es el conjunto de factores no descriptivos pero sí psicológicos, simbólicos y/o estéticos que crean un cierto ambiente. Psicológicamente es un elemento estético que afecta a la percepción de la sensibilidad.

\section{Color denotativo}

Es denotativo un color cuando se utiliza como representación de la figura, u otro elemento, es decir, incorporado a las imágenes reales de la fotografía o la ilustración. Podemos distinguir tres categorías de color denotativo: Icónico, saturado y fantasioso, aunque siempre resaltando la iconicidad de la forma que se presenta.

\section{Color fantasioso}

La fantasía o la manipulación del color, nace como expresión creativa, son las imágenes que se colorean a mano, no se altera su forma, pero sí el color, por ejemplo una pera de color azul.

\section{Color icónico}

Es un color icónico el que expresa cromáticamente una función identificadora, por ejemplo la tierra es marrón, la granada es roja y el cielo es azul. El color permite la identificación rápida del icono o figura representada. Podríamos afirmar que el color ejerce una función más realista en nuestra mente ya que se superpone a la forma de las cosas.

\section{Color saturado}

Es una forma de color que está alterado o manipulado normalmente es más brillante, más denso y luminoso. En la comunicación y lenguaje publicitario así como en la ilustración resulta muy útil y da como resultado colores más atractivos y diferentes creando euforia en quien lo contempla.

\section{El empaquetado o también llamado packaging}

Asociado al color y de forma casi inseparable tenemos la forma del empaquetado o packaging que es un valor añadido al producto muy 
importante en el proceso de elección y compra El valor del empaquetado en el proceso de venta es primordial.

El packaging desde un punto de vista no lingüístico podríamos definirlo como la ciencia, el arte y la tecnología para la inclusión y protección de productos para su venta, distribución y almacenaje. Desde la óptica de la creación publicitaria se considera que el empaquetado tiene como objetivo principal atraer la atención del consumidor. Es un mensaje a veces incluso el principal del producto, la marca y el fabricante hacia el consumidor.

La tendencia es que las marcas presten mucha atención al envoltorio considerando éste muy importante para la decisión final de compra del cliente. Además de la marca del imagotipo el envoltorio es parte fundamental del producto a la hora de mostrarlo al cliente.

Los elementos como el color y la forma del envase comunican como es el producto y transmiten información del producto en sí mismo y de la empresa y marca que lo manufacturan.

Es importante que el empaquetado o envoltorio impacte, cause una impresión agradable y positiva; que sea creativo, actual y novedoso. Eso es fundamental para que el consumidor nada más verlo decida si le gusta o no y si elige ese producto. Debe despertar el deseo de pertenencia al igual que la marca.

Las formas en el empaquetado de los objetos y productos lo que en comunicación, más concretamente en marketing, se denomina packaging debe de evocar emociones, sensaciones, experiencias debe imprimir huella.

Aunque pueda resultar sorprendente, a veces existen productos de una calidad más bien mediocre, pero que tienen un packaging atractivo y tienen un gran éxito de venta y penetración en los públicos.

El segmento del público femenino es uno de los más considerados y tenidos en cuenta por el marketing. Muchas marcas han optado por 
teñir de rosa sus envases, con el fin de satisfacer al público femenino y que se ha extendido también al masculino.

A veces la etiqueta cumple las funciones del packaging, es decir, la etiqueta per se comunica toda la información que el producto y la marca quieren transmitir al consumidor. Por ejemplo en una botella de cerveza en que la que el envase es similar en todas las marcas la distinción está precisamente en la etiqueta que nos indica, atrae y comunica sobre el producto. En base a la etiqueta identificamos, seleccionamos y elegimos.

El envoltorio de un producto debe tener unas características físicas y de contenido como son la utilidad, la innovación y la sostenibilidad.

\section{La utilidad}

Antes era importante la utilidad era lo esencial pero ahora además de ésta debe contener elementos que hacen del envoltorio algo atractivo y objeto de deseo. De hecho se coleccionan envoltorios desde la etiqueta, la bolsa, el papel, la caja, el estuche, la botella y otros.

\section{La innovación}

Debe ser lo suficientemente novedoso contener grandes dosis de creatividad que diferencien el producto de la competencia ya sea en forma, calidad de la materia prima con la que está elaborado y el color así como el logotipo y quizá el concepto del mismo.

Además debe de contener una cuota de seducción implícita en la imagen integral que solo se percibe a nivel sensorial y emocional. Una consideración en el diseño es la de contemplar varias versiones en las que incluiremos las de las promociones que llevaran la marca que el distintivo que los distinga y dejando espacio para poner etiquetas o advertencias para el cliente.

\section{La sostenibilidad}

Debe también responder a las necesidades de los consumidores en cuanto a la sostenibilidad se refiere ya que es importante velar y cuidar el medioambiente, solo tenemos este mundo y lo debemos respetar y cuidar. Todos debemos poner nuestro grano de arena en se 
sentido. Es uno de los elementos que satisface las emociones y la sensibilidad de los públicos y del consumidor.

En algunos productos como las botellas la etiqueta sirve de packaging, el envase digamos que es el mismo pero la etiqueta es distinta y además de informar comunica.

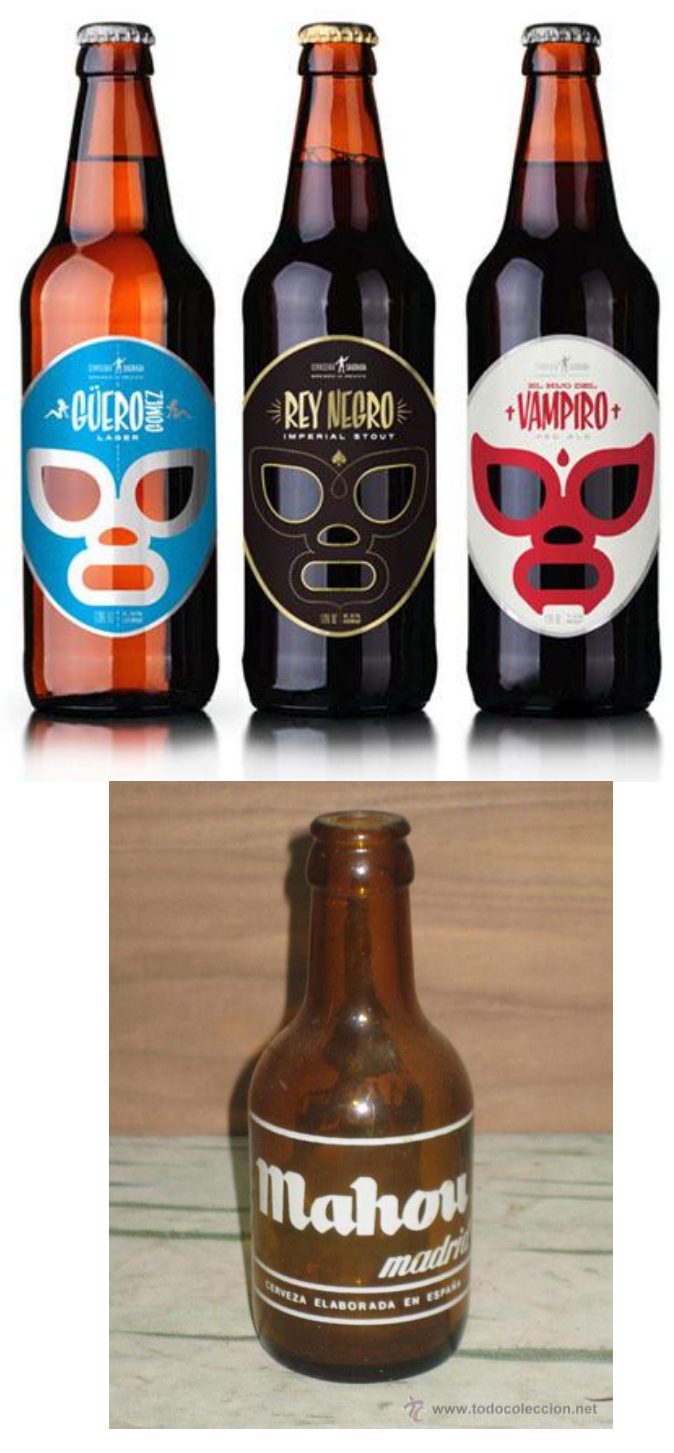

Fuente: www.todocoleccion.net/botellas

El envase de una botella de agua puede ser simple, de vidrio o plástico que no requiere ni mucha innovación, ni diseño ni sostenibilidad. Con el avance tecnológico y el desarrollo de nuevos materiales así como con la creatividad en el diseño esto ha cambiado. 
Existen botellas de agua mineral que parecen de Existen botellas de agua mineral que parecen de perfume o de agua de colonia.

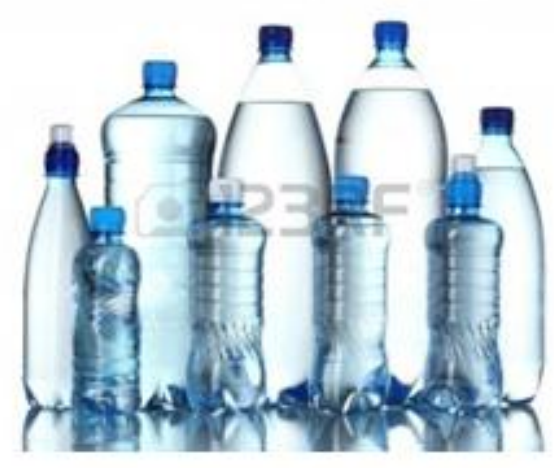

Fuente: http://goo.gl/9Ye4IH

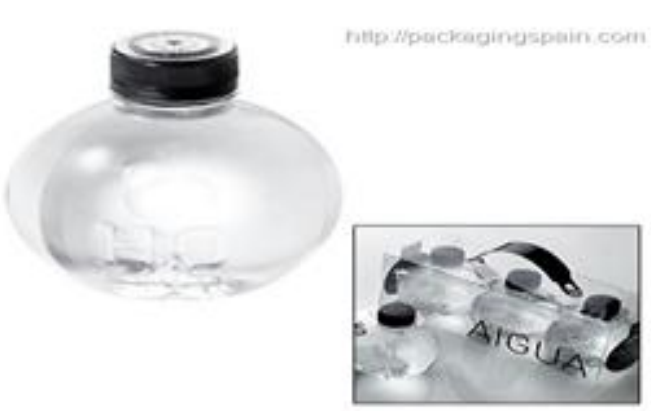

Fuente: http://www taringa.net

Y para finalizar analizamos el envoltorio de un simple cucurucho de churros. Antes, una simple bolsa de papel de estraza valía para contener y transportar los churros, ahora encontramos un triángulo invertido de una cartulina de papel reciclado fina con un soporte para el chocolate (evita el tener que usar en ciertos momentos una taza de porcelana). Nos satisface, es creativo, es innovador, tiene utilidad y cumple con la sostenibilidad.

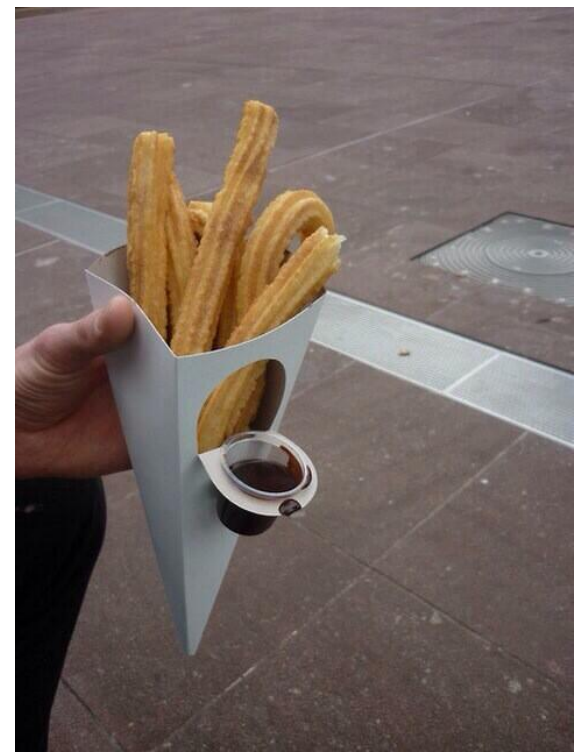

Fuente: http://goo.gl/wTRl2d

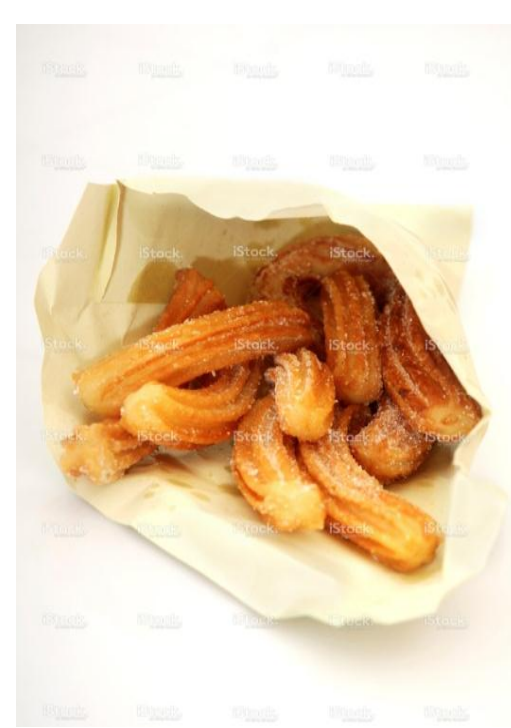

Fuente: http://goo.gl/eAgRGK 
A veces las empresas con el interés de penetrar más en los públicos y en el imaginario de los consumidores intentan cambiar a través del color, un ejemplo muy claro es el de la compañía Coca-Cola. La bebida de cola ha hecho variantes en función de alguno de sus componentes: por ejemplo la clásica con azúcar y cafeína de color rojo, la light sin azúcar de color plateado, la de sin cafeína en oro y a cada una de las variedades le ha puesto un color diferente.

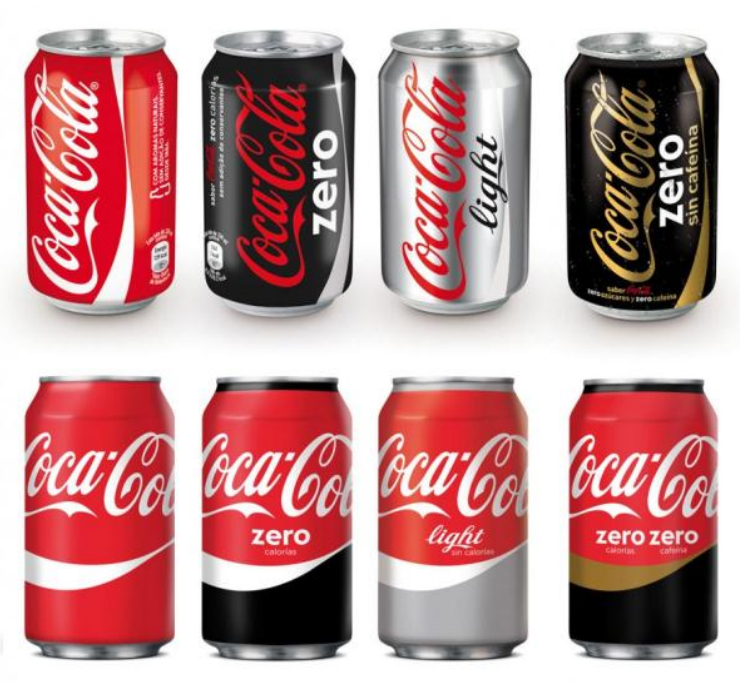

Fuente: http://www.cocacola.es

Pero eso ha creado cierta confusión en el consumidor y ahora desde han decidido que todos sus productos serán del mismo color, del rojo originario y genuino, el corporativo de la marca.

La distinción de variedad se encuentra visible en la base de la lata.

\section{Referencias}

Bassat, L. (2006). El libro rojo de las marcas. Barcelona. Debolsillo.

Edwards, B. (2006). El Color. Un método para dominar el arte de combinar los colores. Barcelona. Ed. Urano.

Pricken, M. (2006). Publicidad creativa. Barcelona. Ed. Gustavo Gili.

Sevillano, M. (2004). El libro rojo de la imagen. Madrid. Dossat 2000.

Diario ADN-Consumo Tendencia. (15.12.2010) "Los dueños del color". 


\section{La comunicación y el entorno del público externo en las organizaciones sanitarias}

Ana María Mañá Álvarez

Universidad de Santiago de Compostela

\section{Resumen}

Las organizaciones sanitarias, entendidas como empresas de servicios, orientan su política de comunicación externa al usuario activo (paciente hospitalizado, en consulta externa,...). El objetivo fundamental es alcanzar un óptimo nivel de confianza en cuanto a garantías y calidad del servicio prestado en respuesta a una demanda previa por parte del usuario. Pero partiendo de la teoría de que el ser humano debe ser considerado como un todo bio-psico-social, se hace necesario incluir también, en el conjunto de públicos externos de las organizaciones sanitarias, a los miembros del entorno social del usuario del servicio de salud dispensado: su familia, sus amistades y otros usuarios potenciales de la organización. Una adecuada gestión de la comunicación en el entorno del usuario permite mejorar tanto su propia satisfacción, como la imagen que proyecta la organización sanitaria.

Palabras clave: Comunicación; hospital; organización; usuario.

\section{Introducción}

T A comunicación de una organización sanitaria es un proceso de $\mathcal{L}$ interacción social continuo entre la entidad y su entorno. Toda organización sanitaria puede ser considerada como un sistema abierto 
en continuo intercambio con la sociedad de la que forma parte.

Las acciones de comunicación en las organizaciones sanitarias requieren la determinación de un mapa de públicos y la definición de las características de los mismos (Túñez, 2012), considerando que se trata de individuos y grupos relacionales (familias, amigos,...) cuya actitud ante la organización va a evolucionar y modificarse en función de las circunstancias que les rodean.

A la hora de interaccionar organizacionalmente podría hablarse de dos procedimientos básicos: la comunicación interna (que hace referencia a la que mantienen los miembros de la organización entre sî y también la comunicación externa (que nos lleva a ver la transmisión de información con personas y grupos del exterior).

Según todo esto y, tal como indica Lucas Marín (1997), para una adecuada gestión de la comunicación, deberá tenerse en cuenta que toda organización sanitaria, como empresa de servicios, recibe de la sociedad unas influencias (inputs), ofrece unos resultados (outputs) y que sobre ella influyen tanto variables internas (que se interrelacionan formando el esquema básico del sistema) como variables externas (que componen el entorno relevante de la organización).

Para una comunicación eficaz no basta con garantizar que el mensaje llegue al público, sino que es imprescindible que sea atendido y entendido (Túñez, 2012); procurando garantizar, asimismo, un feedback adecuado entre la propia organización sanitaria y sus respectivos públicos.

Esta relación con los públicos es el núcleo de la gestión de la comunicación en las organizaciones, por ello se asocia habitualmente la comunicación organizacional con las relaciones públicas.

Grunig y Hunt describen un modelo simétrico bidireccional de relaciones públicas, que ha sido considerado desde finales del siglo $\mathrm{XX}$, como el modelo ideal en la práctica de las relaciones públicas. Se basa en los flujos de comunicación bidireccional entre la organización y sus públicos para modificar la conducta de éstos, pero aceptando que el comportamiento de la organización también puede variar 
como resultado de las actuaciones de comunicación desarrolladas para, de esta forma, mejorar la conducta de la organización y sus públicos a través del entendimiento mutuo de ambos.

También en el terreno del marketing se ha evolucionado y las relaciones han ido sustituyendo a las transacciones como referencia en las actividades comerciales (Kotler, 1997). Esto se ve incrementado, fundamentalmente, en las organizaciones sanitarias, donde la confianza, la credibilidad y el compromiso de la organización con los usuarios, adquieren un valor superlativo.

La satisfacción con el servicio recibido se asocia con un trato diferencial, con una atención sentida como exclusiva por el usuario. Todo ello influye sobre la reputación de la organización sanitaria y la imagen que se crea de la misma en la sociedad de la que forma parte. La buena comunicación es imprescindible en una atención sanitaria de calidad a todos los niveles, pues permite obtener la colaboración tanto del propio usuario del servicio de salud como de su entorno familiar y facilita considerablemente las decisiones terapéuticas.

La Organización Mundial de la Salud define la salud como un estado de completo bienestar físico, psíquico y social y no la mera ausencia de enfermedad. Según esto, el ser humano debe ser considerado como un todo y tratado de forma holística, otorgando importancia similar a las dimensiones emocional y social que la que sea prestada a la dimensión biológica.

Diversos autores reflejan que, para la correcta atención sanitaria de un individuo, es necesario disponer de un concepto amplio y flexible de la realidad que le rodea, aunque lamentablemente, con frecuencia se hace "todo por el paciente pero sin contar con él" (Llubiá, 2008), priorizando los procedimientos tecnológicos e ignorando la dimensión humanística.

Hoy en día y, atendiendo a esa definición de la Organización Mundial de la Salud, la salud constituye un sector de actividad que implica, sin duda, a varios actores sociales. Por ello, cada vez son más las organizaciones que se interesan por este ámbito, tanto las que podrían 
calificarse directamente de sanitarias, como otras que no lo son directamente: hostelería, cosmética... Entre todas las organizaciones sanitarias, destaca sobre todo, el hospital. El hospital es, por el rol esencial que desempeña en la sociedad, el tipo de empresa que la mayor parte de los ciudadanos asocian al concepto de salud.

Una correcta comunicación del equipo de salud con el usuario y su entorno social repercute positivamente en la satisfacción de los públicos externos de la organización sanitaria (Davidson et al., 2007).

Por su cercanía y el tiempo de interrelación que mantiene con el usuario, el personal de enfermería podría considerarse uno de los comunicadores más importantes del hospital (Medina, 2012). Una enfermera competente en las habilidades técnicas, pero capaz de dar atención también a las respuestas emocionales es la considerada como ideal por el paciente y su familia (Blanca et al., 2008).

La comunicación con el entorno del paciente: familiares, amigos,... debe ser también evaluada con regularidad para mejorarla en la medida en que ello sea posible (Santana Cabrera et al., 2007); porque, al igual que la propia organización sanitaria, la familia es también un sistema abierto, que funciona como una unidad y en el que todos sus miembros están íntimamente relacionados, de forma que cualquier efecto adverso que afecte a uno de sus miembros repercute de manera negativa sobre los demás, lo que da lugar a una situación de crisis.

\section{La comunicación del hospital y sus usuarios: pacientes y familiares}

Una de las más evidentes situaciones de crisis a la que pueden tener que enfrentarse una familia y los profesionales sanitarios es aquella que necesita de un giro emocional, desde la esperanza de curación a la aceptación de medidas paliativas o de limitar el soporte vital porque la decisión de los familiares puede quedar condicionada por la forma de exponerles la situación.

Una investigación llevada a cabo en la Unidad de Reanimación y Cuidados Críticos Postquirúrgicos de uno de los principales 
hospitales del Servicio Galego de Saude (SERGAS) en el año 2011 se ha ocupado primero de los públicos internos (análisis de flujos) para centrarse después en las actitudes y niveles de recepción y satisfacción de los públicos/usuarios de la unidad de cuidados críticos (cómo perciben a la organización y cómo reaccionan a sus propuestas), en la organización (cómo puede o debe adaptarse a las reacciones de los públicos) y las relaciones públicas (el grado de efectividad de las actuaciones desarrolladas en los niveles de entendimiento entre la organización y sus públicos).

El estudio de las relaciones entre la Unidad de Hospitalización y los familiares de los pacientes ingresados en ella ha requerido:

a) Elaborar un mapa de flujos de comunicación entre los distintos profesionales sanitarios y entre éstos y los familiares del paciente (figura 1) en el momento del ingreso en Cuidados Críticos y durante la estancia del paciente en esta unidad de hospitalización para poder conocer los fallos de comunicación entre los familiares del paciente crítico postquirúrgico y los distintos miembros del personal sanitario, así como las ausencias o accesos a la comunicación con el paciente durante el proceso de ingreso de éste en la unidad.

b) Realizar un cronograma en el que se reflejasen los tiempos de ausencia de información y de contacto de la familia con el paciente o con el personal sanitario (figura 2). Cabe destacar la extensa franja horaria en la que paciente y familia permanecen separados mientras aquel permanezca ingresado en la unidad de críticos: obsérvese que desde las 22:00h no vuelven a tener contacto hasta las $15: 30 \mathrm{~h}$ del día siguiente; así como la información médica: en un período de 24 horas la familia solamente tendrá acceso en una única ocasión a conocer, de manos de un facultativo, cual es el estado clínico del paciente.

Estas acciones se han desarrollado a partir de un estudio exploratorio transversal en el que se seleccionaron dos muestras de 25 individuos cada una. La primera formada por familiares de pacientes que recibieron el alta de la unidad de cuidados críticos postquirúrgicos en 
las 48horas previas a la recogida de datos y la segunda por familiares de pacientes que habían recibido el alta en la unidad en los seis meses anteriores.

En el primer caso se incluyeron sistemáticamente a los 25 pacientes que fueron dados de alta durante las tres semanas que duró la recogida de datos. En cuanto a la segunda de las muestras, se seleccionaron mediante muestreo aleatorio: a partir de los datos de carácter administrativo de los que se dispone en el Servicio de Anestesia, Reanimación y Terapia del Dolor se elaboró un listado con los números de historia clínica de los 295 pacientes que fueron dados de alta en ese período, ordenado por fecha de ingreso y se seleccionó uno de cada doce, comenzando por el primero de la lista.

La toma de datos se ha realizado mediante encuesta personal, en el caso de los familiares de pacientes que todavía permanecían ingresados en el hospital, y mediante encuesta telefónica para los familiares de pacientes que ya hubiesen recibido el alta domiciliaria en el momento de la recogida de datos. En ambos casos se les presentó el mismo cuestionario.

Las respuestas obtenidas a través de las encuestas reflejan una mayor necesidad de información, pues aunque solamente el 14\% de los consultados consideran que la información que recibieron sobre la salud de su familiar durante el tiempo que permaneció ingresado fue escasa o muy escasa, el 48\% manifiesta que el número de veces que reciben información es poco o muy poco y un $44 \%$ cree que transcurre mucho tiempo, y un $6 \%$ incluso lo califica como "demasiado", desde que son informados hasta la vez siguiente en que pueden recibir información.

Del 34\% de las respuestas relativas a cuál fue el momento del proceso de atención en que ha sentido una mayor necesidad de información relativa al estado de salud de su familiar, que situaban ese momento en la Unidad de Reanimación, el 65\% considera que se encuentra en el intervalo de tiempo que transcurre desde la visita de la noche (21:00h) y la del día siguiente por la tarde (15:30h). 
Si comparamos este porcentaje con el 60\% de los entrevistados que consideran que el número de visitas permitidas es insuficiente $y$, con el $46 \%$ que califican el tiempo permitido para cada visita como poco o muy poco, aunque no se trata de una muestra estadísticamente significativa, podemos intuir que existe una notable necesidad de revisión de flujos y protocolos para aumentar las posibilidades de comunicación de la familia con el personal sanitario y, además, del contacto con el paciente.

La información destaca, por tanto, como una de las principales necesidades de la familia (Bernat, 2008). Ocultar información es mala praxis pero demasiada información, sobre todo repetitiva e insistiendo en un mal pronóstico de forma continuada, también puede serlo. Es peligroso informar sin escuchar previamente hasta qué punto se sabe y hasta dónde se quiere y se necesita saber. Hace falta paciencia para explicar, poner ejemplos y verificar qué es lo que se ha entendido (Villa, 2007).

Figura 1. Flujos de comunicación en el área quirúrgica:

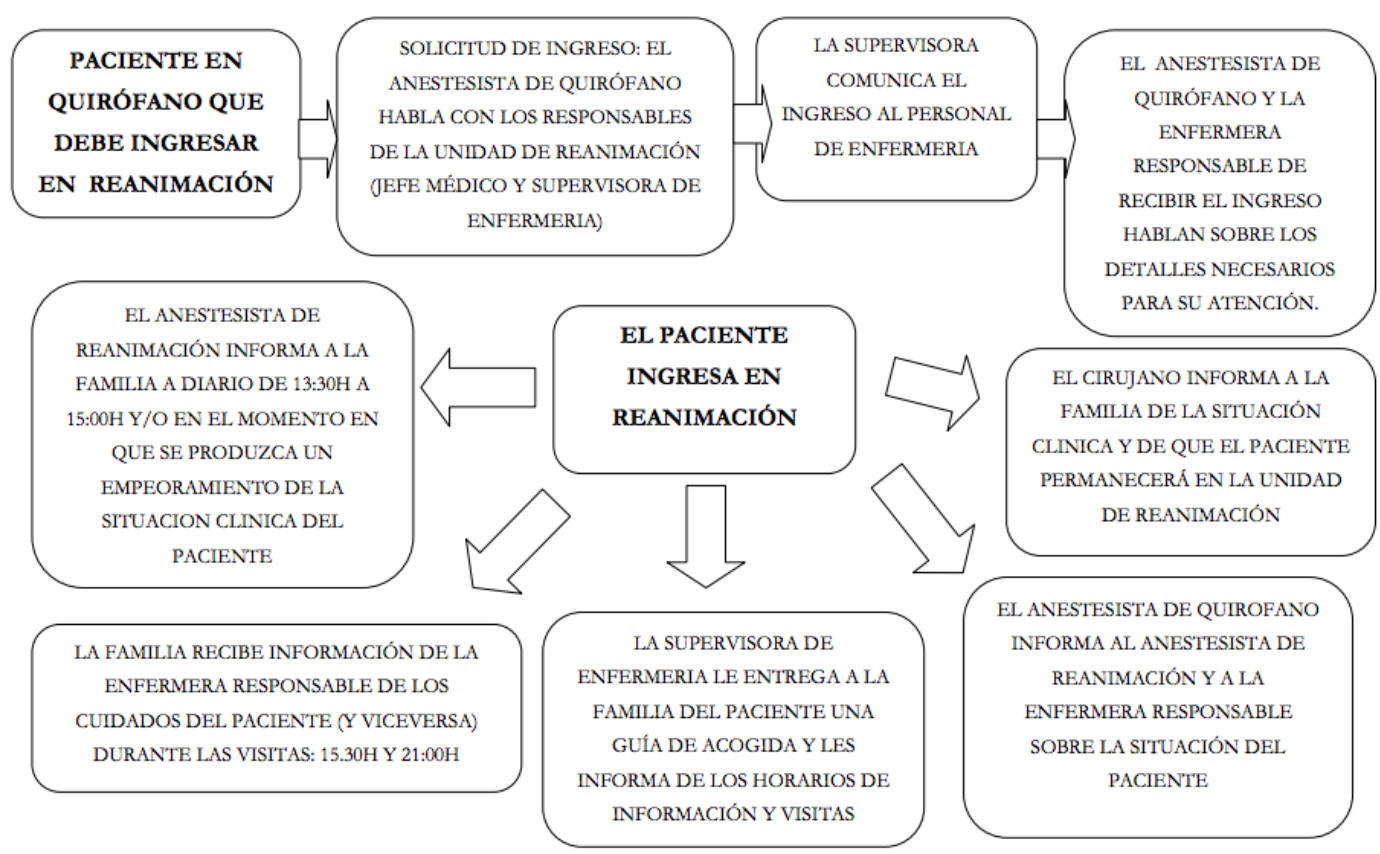

"La gestión de la comunicación en una situación de crisis es la gestión de la credibilidad" (Túñez, 2007); la eficacia de la información que se le ofrece a la familia del usuario depende de que ésta la perciba como transparente y veraz y que no surjan versiones antagonistas que 
perjudicarían, considerablemente la credibilidad del informador y, por extensión también la imagen de la organización a la que representa.

El primer paso es buscar un lugar donde la intimidad, la comodidad y la falta de interrupciones estén garantizadas. Es preferible tardar un poco más en comunicar una mala noticia que hacerlo en un lugar poco apropiado. La información debe darse de una forma clara y concisa, evitando tecnicismos y asegurándose de que está siendo comprendida y asimilada por el receptor.

Mantener la proximidad física, la voz pausada y una mirada serena, así como una escucha activa, mostrando empatía y asertividad y emplear el silencio para permitir la reflexión sobre lo que se ha dicho, son habilidades que contribuyen a disminuir en gran medida el impacto de una mala noticia. Una vez comprendida la información hay que saber cómo se siente el receptor y responder a sus reacciones e inquietudes (Mirón, 2010).

Tomar conciencia de los problemas de los públicos externos, tanto usuario como familia, así como de la satisfacción que tienen con la atención que reciben favorecerá la planificación de los cuidados necesarios y la identificación de los aspectos de la hospitalización que requieren mejoras (Llamas-Sánchez et al., 2009).

Como conclusión podría decirse que una adecuada gestión de la comunicación en el entorno del usuario permitirá mejorar tanto su propia satisfacción, como la imagen que proyecta la organización sanitaria hacia la sociedad.

\section{Conclusiones}

La comunicación con el entorno del paciente: familiares, amigos,... debe ser evaluada con regularidad para mejorarla en la medida en que ello sea posible e incrementar la satisfacción de los usuarios con la organización sanitaria.

La información destaca como una de las principales necesidades de los públicos externos de una organización sanitaria y la eficacia de dicha información depende de que sea transmitida de un modo 
transparente y veraz, favoreciendo considerablemente la credibilidad del informador y, por extensión también la imagen de la organización a la que representa.

\section{Referencias}

Bernat Bernat R. "Necesidades de la familia del paciente crítico: revisión bibliográfica”. Nursing. 2008; 6(9): 60-3.

Blanca JJ, Blanco AM, Luque M, Ramírez MA. "Experiencias, percepciones y necesidades en la UCI: revisión sistemática de estudios cualitativos". Enfermería Global, 2008; 12:1-14.

Davidson JE, Powers K, Hedayat KM, Tieszen M, Kon AA, Shepard E et al. "Clinical practice guidelines for support of the family in the patient-centered intensive care unit: American College of Critical Care Medicine Task Force 2004-2005”. Critical Care Medicine. 2007; 35:605-22.

Definición de Salud (1948). Recuperado el 1 de Abril de 2015, del sitio web de la Organización Mundial de la Salud: http:/ /www.who.int

García Mozo A, Sánchez Roldán F, Amorós Cerda SM, Balaguer Albarracín F, Díez Alcalde M, Durán Torres MT et al. "Desarrollo de una guía de atención a los familiares del paciente crítico". Enfermería Intensiva. 2010; 21(1):20-7.

Grunig JE, Hunt T. Dirección de relaciones públicas. Edición en español de Managins Public Relations. Florida (EEUU): Harcourt Brace Jovanovich; 1984. Barcelona: Gestión 2000 SA; 2003.

Hidalgo Fabrellas I, Vélez Pérez Y, Pueyo Ribas E. “¿Qué es importante para los familiares de los pacientes en una Unidad de Cuidados Intensivos?" Enferm Intensiva. 2007; 18(3):106-14.

Kotler P, Andreasen A R. Strategic marketing for non-profit organizations. $5^{a}$ ed. Upper Saddle River, Nova Jersey: Prentice-Hall; 1996. Llamas-Sánchez F, Flores Cordon J, Acosta Mosquera ME, González Vázquez J, Albar Marín MJ, Macías Rodríguez C. "Necesidades de los familiares en una Unidad de Cuidados Críticos". Enferm Intensiva. 2009: 20(2): 50-7.

Llubiá C. "Cuidados críticos: La comunicación como terapia imprescindible". Psicooncología. 2008; 5(2-3): 233-43.

Lucas Marín A. La comunicación en la empresa y en las organizaciones. Barcelona: Bosch Casa Editorial, 1997. 
Medina Aguerrebere P. Comunicar y curar. Un desafío para pacientesy profesionales sanitarios. Barcelona: Editorial UOC; 2012

Mirón González R. "Comunicación de malas noticias: perspectiva enfermera”. Rev Esp Com Sal. 2010; 1(1):39-49.

Robbins, Sthephen, Judge T. Comportamiento organzacional.13 $3^{\mathrm{a}}$ ed. México: Pearsons Educación; 2009.

Santana Cabrera L, Sánchez Palacios M, Hernández Medina E, García Martul M, Eugenio Robaina P, Villanueva Ortiz A. "Necesidades de los familiares de pacientes de Cuidados Intensivos: percepción de los familiares y del profesional". Med. Intensiva. 2007; 31(6):27380 .

Santana Cabrera L, Yáñez Quintana B, Martín Alonso J, Ramírez Montesdeoca F, Roger Marrero I, Pérez de la Blanca AS.

"Actividades de comunicación del personal de enfermería con los familiares de pacientes ingresados en una unidad de cuidados intensivos". Enferm Clin. 2009; 19(6): 335-9.

Sobrino López A. "Comunicación de malas noticias". Semin Fund Esp Reumatol. 2008:9:111-22.

Túñez López M. Comunicación preventiva. $1^{\mathrm{a}}$ ed. A Coruña: Netbiblo; 2007.

Túñez López M. La gestión de la comunicación en las organizaciones. Zamora: Comunicación Social; 2012

Villa López B. "Recomendaciones sobre cómo comunicar malas noticias". Nure Investigación. 2007; 31

Zaforteza Lallemand C, García Mozo A, Quintana Carbonero R, Sánchez Calvín C, Abadía Ortiz E, Albert Miró Gaya J. “Abrir la unidad de cuidados intensivos a los familiares: ¿Qué opinan los profesionales?”. Enferm Intensiva. 2010; 21(2):52-7.

Zaforteza Lallemand C, Prieto González S, Canet Ferrer TP, Díaz Lopez Y, Molina Santiago M, Moreno Mulet C et al. "Mejorando el cuidado a los familiares del paciente crítico: estrategias consensuadas". Enferm Intensiva. 2010; 21(1):11-9.

Zaforteza C, Sánchez C, Lastra P. "Análisis de la literatura sobre los familiares del paciente crítico: es necesario desarrollar investigación en cuidados efectivos". Enferm Intensiva. 2008; 19(2):61-70. 


\section{Del Dircom al Marcom, un proceso de evolución de la comunicación}

Cesibel Valdiviezo y Karina Valarezo

Universidad Técnica Particular de Loja, Ecuador

\section{Resumen}

La modernidad ha traído consigo un gran desarrollo tecnológico, económico, cultural y social. Junto a ello, también cambian los públicos, convirtiéndose en más exigentes, demandando procesos transparentes, competitividad en la calidad de los productos o servicios, una clara rendición de cuentas y un buen manejo de la comunicación a nivel interno y externo por parte de las organizaciones.

Como respuesta a estas exigencias, surgieron las Direcciones de Comunicación-Dircom ${ }^{25}$, para entre otras funciones, coordinar procesos de comunicación a nivel interno y externo, para facilitar el trabajo entre la institución y los públicos objetivos. Que sean coordinados por un profesional líder, gestor y responsable de la

\footnotetext{
${ }^{25}$ Dircom, es un acrónimo de Director de Comunicación y es una denominación, aceptada en Europa y América Latina, para referirse a los Directores de Comunicación. En el presente escrito se utilizará dicha abreviatura para referirse a los Directores de Comunicación de una manera abreviada.
} 
comunicación, que tenga visión, que conozca la organización, sus públicos y tenga las competencias académicas para dirigir y coordinar un equipo de comunicación.

Todo ello, no ha sido suficiente y la exigencia es mayor, el Dircom está viviendo un proceso de evolución al denominado Marcom, que es la fusión de la comunicación institucional, el marketing y la publicidad, donde se persigue un trabajo de manera integral, bajo un mismo paraguas comunicacional.

\section{Palabras claves}

Dircom, Dirección de Comunicación, Marcom, Marketing y Comunicación, estratégica, comunicación.

\section{La comunicación actual}

— L siglo XXI constituye un período de avances tecnológicos en las comunicaciones, desde el experimento de Marconi en 1901 de enviar señales por radio a través del Atlántico, hasta el fenómeno de expansión de la industria electrónica e informática, que han provocado una profunda revolución, caracterizada especialmente por la aparición de dispositivos multimedia y por una expansión espectacular de las redes telemáticas, que permiten, entre otros beneficios, interactuar entre públicos a grandes distancias geográficas.

Este avance de la tecnología ha permitido que los procesos y las formas de comunicación evolucionen, llegando así a la era de la participación, donde los públicos y las empresas interactúan y se retroalimentan de contenidos y de información, en la mayoría de los casos de manera instantánea.

Es innegable aceptar el papel que ha tenido la tecnología para alterar las reglas de juego en comunicación, ello ha supuesto un cambio drástico en las dinámicas de trabajo, lo que exige a las instituciones renovar sus procesos de comunicación y las dinámicas de labor comunicacional para adaptarse a las nuevas transformaciones.

En las organizaciones se trabajan dos tipos de comunicación, por un lado están las Relaciones Públicas que se enfocan a la comunicación 
institucional y buscan establecer vínculos con los distintos públicos, escuchándolos, informándolos y persuadiéndolos para lograr fidelidad, credibilidad y buena reputación hacia la empresa; y por otro lado, el marketing que pretende captar a los clientes a través de productos o servicios que pueden ayudar a satisfacer sus necesidades.

Ambas disciplinas profesionales han sido bien marcadas y definidas desde su surgimiento, donde cada una tiene roles y funciones distintas, pero siempre conectados entre sí.

Tradicionalmente en las organizaciones las Relaciones Públicas se han manejado desde el Departamento de Comunicación y el Marketing desde el área de Mercadeo y/o Publicidad, siendo profesionales distintos los que los coordinan.

\section{Proceso de evolución}

La consolidación de un sistema comunicativo eficiente dentro de una organización puede determinar la prevalencia de la misma, pues la influencia que tiene no solo se concentra en el logro de los objetivos comunicacionales sino también permite la formación y afianzamiento de los lazos dentro y fuera del núcleo institucional, siendo esta una herramienta certera para el incremento de la productividad.

Para lograr la efectividad en la comunicación dentro de la organización Ayón, considera dos factores esenciales; el primero, corresponde al sistema integral de comunicación; y, el segundo, a la persona capacitada que lo hará efectivo (Ayón, 2006). La consideración de estos dos factores evitará el surgimiento de problemas dentro de la gestión de la organización así como también facilitará el cumplimiento de las funciones principales de la comunicación.

Está claro que la comunicación es una herramienta estratégica para llegar a los públicos y permite gestionar una buena imagen y lograr una positiva reputación institucional. Dentro de este proceso son piezas claves los Directores de Comunicación-Dircom, quienes deben poseer un perfil polivalente, con grandes habilidades personales y una amplia formación académica y profesional. 
José María La Porte en (Mora, 2009: 36) expresa que la comunicación institucional guarda muchos antecedentes históricos, pero como disciplina se ha consolidado a mediados del siglo XX, cuando surgió la necesidad de comunicar a los públicos, productos o servicios de forma masiva. Para muchas empresas incorporar la comunicación dentro de sus estructuras ha significado un gran reto. La dinámica de trabajo y la visión de las empresas desde los años 50 hasta la actualidad han cambiado. En un principio eran generadoras de capital y mano de obra para la producción, con el único fin de obtener ganancias económicas.

Esta realidad se mantiene por los años noventa, cuando el $65 \%$ del valor de una empresa sigue dependiendo de sus activos materiales y el $35 \%$ corresponde a los intangibles. Para entonces las empresas se preocupan más por la infraestructura, productividad, y el crecimiento empresarial (Kendrick, 1994)

Pero a principios de la segunda década del siglo XXI, se considera que esta proporción se ha invertido. Los intangibles constituyen el $70 \%$ del valor de una empresa y el 30\% está formado por los bienes materiales (Daum, 2003: 35). En el informe de la Publicidad y Corporate en España, (Villafañe, 2000) expresa que "la comunicación corporativa comprende formas de comunicación cuyos públicos destinatarios no se definen como consumidores de productos (...), sino como interlocutores sociales". Hoy la comunicación se evidencia en el cambio de una gestión de valores tangibles a una gestión de las percepciones, una reputación institucional y la imagen de marca (Capozzi, 2005).

En la denominada sociedad del conocimiento los responsables de comunicación deben ser creativos para identificar instrumentos adecuados para transferir el conocimiento. La difusión, la reutilización y la socialización de conocimiento serán procesos necesarios (Martín, 2007: 56). La comunicación se convierte en una herramienta clave para comunicar la identidad corporativa y a través de ella transferir valor a sus públicos y a la sociedad en la que está inserta. 
En esa misma línea, Joan Costa expresa que si la comunicación no actúa no existe, porque "la comunicación es acción y la acción es comunicación (...). Comunicar es sustancialmente actuar (...)" (Benavides \& Villafañe, 2001: 50). Caprioti expresa que todo lo que la empresa comunica recae en su imagen y la coloca como un miembro de la sociedad, como un sujeto social (Capriotti, 1999: 86).

Con estos cambios, producto de transformaciones constantes, las empresas evalúan y reflexionan sobre la imagen que los públicos tienen de ellas, considerando fundamental incorporar en su estrategia, áreas de comunicación que manejen la comunicación de forma integral.

\section{3. ¿En qué evoluciona el Dircom al Marcom?}

Para 1919, año en el que Edward Bernays utilizó el término consejero de relaciones públicas, las empresas estratégicamente utilizaban la comunicación para mejorar la imagen deteriorada por dificultades económicas poco éticas y mal administradas, conflictos entre países y problemas laborales.

A partir de esto, las empresas e instituciones públicas y privadas, empezaron a crear estructuras de comunicación, en un principio escasas de personal y pocos equipos para la producción de contenido. Los primeros resultados se reflejan a través de iniciativas privadas en nuevos medios de comunicación, aparece entonces, el panorama de las libertades informativas.

Años después, nace el término Dircom, promovido por Entreprises et Médias, Asociación de los Dircom franceses (Costa, 2011: 92). El reconocimiento como profesión se sitúa en el primer Congreso TOPCOM organizado en Francia en 1988. Entre los objetivos que se marcaron sus organizadores y participantes se encontraba realizar un documento que incluyera las funciones del profesional de la comunicación en las organizaciones (Morales-Lugo \& Enrique, 2007: 84). Se presentaba al nuevo profesional como el nuevo director de comunicación global y entre algunas de sus funciones consta ser el responsable de coordinar la publicidad de productos y marcas. Ser el 
responsable de desarrollar las Relaciones Públicas, tener contacto con los medios de comunicación, la comunicación con los poderes públicos, bancos y universidades, el patrocinio, el mecenazgo, el marketing, la decoración interior, la elección de despachos (MoralesLugo \& Enrique, 2007: 84).

De todas las carreras afines al Director de Comunicación es la de Relaciones Públicas la que define la política de comunicación de la organización, la planificación estratégica, la gestión de la cultura, identidad, imagen y reputación corporativa, relaciones con los accionistas, relación con los medios, instituciones, administraciones públicas, responsabilidad social y gestión de la comunicación en situaciones de crisis (Morales-Lugo \& Enrique, 2007: 90). Gruning por su parte afirma que las Relaciones Públicas es: "La función característica de dirección que ayude a establecer y mantener unas líneas de mutuas comunicación, aceptación y cooperación, entre una organización y sus públicos" (Grunig \& Hunt, 2000: 53).

La idea inicial del Dircom era fusionar la comunicación institucional con la publicitaria, pero del todo no ha logrado resultado, porque paralelo a ello, el marketing también ha venido funcionando como una disciplina que trabaja en vender servicios y/o productos a los consumidores. Ambas disciplinas desde la academia se han trabajado desde área diferentes, considerando también así el criterio de organismos internacionales.

Con el invento de la imprenta en 1450, surge la posibilidad de aparecer por primera vez la publicidad impresa. A partir de ello, existe el interés por realizar estudios de mercado y fundar agencias de publicidad, existentes hasta la actualidad.

El marketing no se aleja de la realidad del Director de Comunicación, para la American Marketing Association ${ }^{26}$ (Asociación Americana de Marketing, AMA, por sus siglas en inglés) el marketing es "una

\footnotetext{
${ }^{26} \mathrm{La}$ (Asociación Americana de Marketing), se fundó en el año 1937 y está conformada por más de 30.000 profesionales del marketing, educadores y estudiantes de cualquier lugar del mundo. www.ama.org
} 
función organizacional y un conjunto de procesos para generar, comunicar y entregar valor a los consumidores, así como para administrar relaciones con estos últimos, de modo que la organización y sus accionistas obtengan un beneficio" (The American Marketing Association, 2014).

Para (Porcu, Del Barrio, \& Kitchen, 2012):

"la comunicación ha sido tradicionalmente abordada y gestionada desde el punto de vista funcional, con el claro objetivo de persuasión. (...) Sin embargo, un enfoque relacional de la comunicación es un concepto más amplio que va más allá de la persuasión y pretende (...) alcanzar tres objetivos principales: informar, escuchar y responder".

\section{4. ¿De dónde surge el Marcom?}

Frente a estas dos disciplinas, se hace una fusión y surge el Marcom que es la conjugación de dos áreas de la comunicación, Marketing y Comunicación. El profesional que cumpla el rol de Marcom dentro de la organización debe poseer un alto nivel de formación profesional, sus competencias deben estar en la vanguardia de las exigencias de la modernidad. Debe planificar la comunicación de la organización de manera integral, partiendo de los objetivos, visión, misión y valores de la institución.

Este profesional asume la responsabilidad de integrar la comunicación institucional y la comunicación mercadológica bajo una misma línea comunicacional. Vela por los activos intangibles: la imagen, marca y reputación corporativa. Lo que coincide con McDowell quien afirma que el Dircom debe dejar de ocuparse de los atributos funcionales o utilitarios, y ocuparse de las características abstractas intangibles, emocionales y generar un valor añadido (McDowell, 2011). Su habilidad profesional le debe hacer encontrar las estrategias de comunicación efectivas para conectar las necesidades de las audiencias con la empresa. 
El Marcom garantizará a nivel interno un buen equipo de trabajo y la calidad de servicios y productos que éstos ofrezcan a los miembros de la organización.

Las exigencias modernas le obligan a ser un profesional lleno de creatividad y con dotes de estratega, a buscar la integralidad de la comunicación.

A través de la comunicación; es decir, desde Relaciones Públicas, se debe gestionar contenido de interés y buscar canales de comunicación basados en las preferencias de los públicos. Desde la óptica del marketing debe hacer que esos contenidos se conviertan en potencialidades para atraer más clientes. Esa conjugación de trabajo se logra con la puesta en marcha del Marcom.

Al referirse a la generación de contenido en el libro blanco de Dircom, se propone una evolución del actual Director de Comunicación-Dircom a Director de Contenidos-Dircon, lo cual para muchos pensadores es lógico y razonable (Kantar, 2013: 4). En este documento se expresa que esta evolución supone que el profesional debe cuidar la comunicación tradicional y la digital. Donde la generación y difusión de contenido se ha convertido en la clave para conectar la organización con los públicos.

Quien se desempeñe como Marcom debe tener una formación integral. Su perfil profesional y académico debe ir acompañado de una continua autoformación. Al igual que el Dircom debe poseer un espíritu crítico, tener una actitud positiva, receptiva y abierta, disposición fresca, analítico y calculador, saber evaluar con rigor las ideas, situaciones y decisiones institucionales, imaginativo, buscar nuevas relaciones estratégicas, enfocar las cosas desde una perspectiva no tradicional.

Debe escuchar, comprender y desarrollar su capacidad de empatía con los demás, ser buen argumentador, tener un espíritu independiente y tener la humildad de un aprendiz permanente y ser autodidacta constante. 
Ana Almansa (Almansa, 2004: 52) da a conocer el pensamiento de Westphalen y Piñuel (1993: 822-823) sobre la figura del Dircom y en la que es muy coincidente con el papel que debería cumplir el Marcom, esta se expresa que:

"el responsable encargado de la comunicación publicitaria y de la no publicitaria. (...). Su status, sus cometidos y responsabilidades varían según los casos. Se encarga de las relaciones con la prensa, y asume total o parcialmente las responsabilidades siguientes: comunicación institucional comunicación interna, comunicación financiera, comunicación visual y audiovisual, ediciones, estudios y proyectos de comunicación, relaciones públicas, organización de acontecimientos y manifestaciones externas de la empresa, sponsoring, mecenazgo, etc., y supervisión de la comunicación de producto, la profesional "bussines to bussines" y la publicitaria. Cualesquiera que sean sus atribuciones, el director de comunicación es el portavoz habitual de la empresa ante sus diferentes públicos, internos y externos. En unas empresas se encuentra integrado en el departamento de marketing y en otras, directamente vinculado a la dirección general de la empresa o a su presidencia. El director de comunicación trabaja con las agencias de comunicación o de publicidad, y con los diferentes prestatarios externos de servicios de comunicación (institutos de investigación social, talleres gráficos, editores, impresores, ilustradores, etc.)".

Estos elementos se ajustan a la nueva figura del Marcom y pueden ser gestionados de manera integral, desde un único equipo de comunicación.

Actualmente muchas organizaciones coordinan la comunicación desde áreas diferentes, por un lado la comunicación publicitaria y por otro la no publicitaria, haciendo en algunos casos que los mensajes y los recursos se dupliquen y en otros se llegue a confundir al público. Por lo tanto, lo que persigue el Marcom, es integrar en su totalidad el área de comunicación y que este a su vez trabaje de manera coordinada con todas las áreas que componen el equipo de 
comunicación. Así mismo, este coordinará con la máxima autoridad la política de comunicación de la institución.

Como se ha mencionado anteriormente, el trabajo del Marcom debe estar basado en la planificación, pero también deben medirse todos los resultados e impactos de las estrategias que se plantee, que incluirán temas publicitarios y comunicacionales.

En el siguiente gráfico se muestra como sería la fusión de la comunicación y el marketing, dando como resultado el Marcom, que se convierte en la hibridación y complemento entre las dos disciplinas.

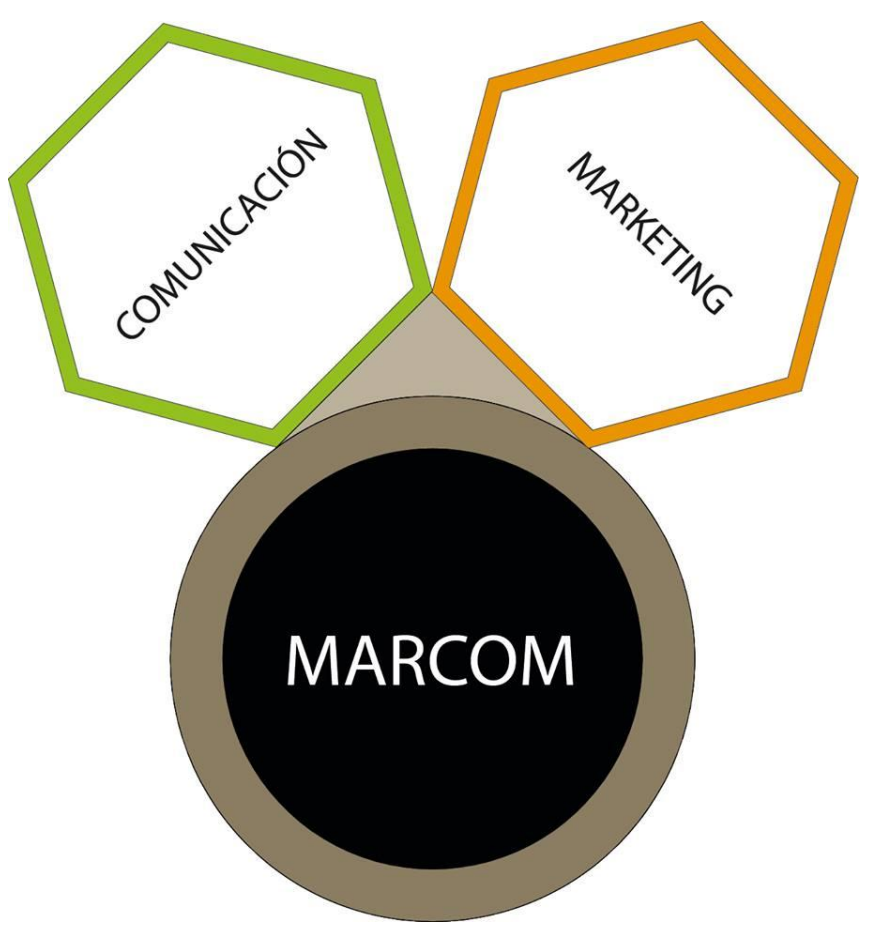

Gráfico 1. Propuesta de Marcom. Elaboración propia.

Las funciones del Marcom pueden ser múltiples, éstas pueden variar y depender del tamaño y la dinámica de trabajo de la organización. Nunca serán fijas y estarán en constante evolución. Actualmente quienes se dedican a la comunicación son gestores de intangibles y la tendencia en los próximos años marca hacia el mismo horizonte.

Así mismo quienes son parte del Marcom deben ser profesionales colaboradores y expertos en el planteamiento de estrategias de 
comunicación. La construcción de la comunicación puede estar apoyada en el modelo RACE (siglas en inglés) y acuñado por John Marston en 1963: investigación, acción, comunicación y evaluación (Xifra, 2005: 84). Modelo que sigue vigente desde su creación y considerado básico en la gestión de la comunicación en las organizaciones.

La tecnología también es un elemento clave en la gestión del trabajo del Marcom, el manejo y conocimientos en redes sociales, indicadores de medición de calidad y reputación online, SEO, SEM, entre otros aspectos son claves para evidenciar y fortalecer procesos de comunicación a nivel interno y externo. Cuando hablamos de la evolución del Dircom al Marcom, se puede identificar una gama de palabras claves que hacen referencia al ejercicio del profesional de la comunicación.

Estas terminologías guardan una estrecha relación entre ellas y están presentes absolutamente en todo el accionar de la comunicación, ya que abarcan temas de marketing y comunicación, propios de la gestión comunicacional. Veamos a continuación la imagen que resume en palabras claves el trabajo que debe realizar el Marcom:

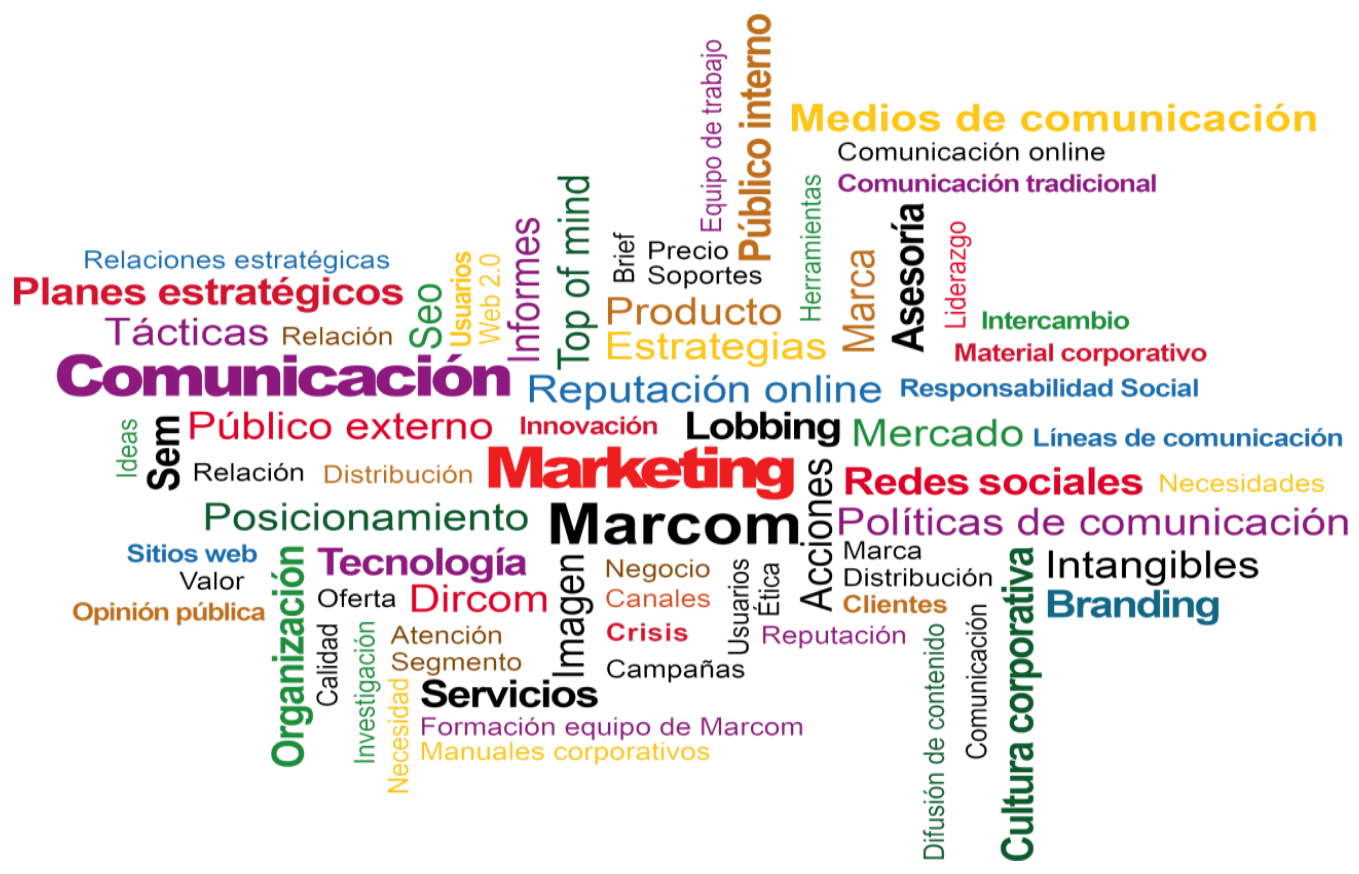

Gráfico 2. Terminologías claves del Marcom. Elaboración propia. 
De esta gráfica se puede destacar elementos prioritarios como el marketing y la comunicación y otros que a su vez giran en torno a ellos y permiten una comunicación integral, que viene siendo el Marcom.

En la realidad actual, la tendencia de la comunicación apunta hacia herramientas digitales y comunicación online; por ello, es fundamental que el Marcom esté preparado y siempre alerta a todos los cambios, pero especialmente dispuesto a adaptarse a los procesos de metamorfosis que la sociedad moderna los exige. Incluso en la misma propuesta de terminologías vemos como algunos elementos afirman este planteamiento.

Para el Marcom los públicos seguirán siendo el eje transversal a su gestión y los más importantes al momento de investigar, planificar, comunicar y evaluar la comunicación. Es en torno a ello que giran las organizaciones y los cambios y tendencias.

Finalmente se recalca que el Marcom debe poseer una visión de estratega y debe utilizar el buen juicio para la toma de decisiones oportunas a nivel institucional tanto con la comunicación tradicional y la comunicación digital.

\section{Conclusiones}

Las organizaciones evolucionan y la comunicación también. Por lo tanto; es necesario, que las áreas de comunicación dentro de la dinámica de las organizaciones también cambien y se adapten a las exigencias modernas tanto de los públicos como de los contextos donde se encuentran.

Actualmente se requiere de procesos de comunicación integrales, donde se atienda a los diferentes públicos y se cuide la imagen de la organización.

La fusión del marketing y la comunicación puede dar cabida al Marcom, figura estratégica en el manejo de la comunicación integral de la organización. 
El Marcom deberá integrar la comunicación institucional y la comunicación mercadológica bajo el mismo paraguas comunicacional.

\section{Referencias}

Almansa, A. (2004). Teoría, estructura y funcionamiento de los gabinetes de comunicación. El caso andaluz.Málaga: Universidad de Málaga,

Ayón, R. (2006). "Importancia de la comunicación en las organizaciones, un sistema de comunicación eficiente y un experto en comunicación que lo administre". Benavides, J., \& Villafañe, J. (2001). Dirección de comunicación empresarial e institucional. Barcelona: Gestión 2000.

Capozzi, L. (2005). "Corporate reputation: Our role in sustaining and building a valuable asset". Journal of Advertising Research, 45(3), 290-293. doi:10.1017/S0021849905050324.

Capriotti, P. (Ed.). (1999). Planificación estratégica de la imagen corporativa. Barcelona: Ariel.

Costa, J. (Ed.). (2011). El ADN del dircom (1a. ed. ed.). Barcelona: Granolers.

Daum, J. H. (2003). Intangible assets and value creation. Chichester: John Wiley \& Sons, Ltd.

Grunig, J., \& Hunt, T. (Eds.) (2000). Dirección de relaciones públicas. Barcelona: Gestión 2000.

Kantar, M. (2013). El cambio boy en día. Director de comunicación y marketing

Kendrick, J. (1994). "Total capital and economic growth". Atlantic Economic Journal, 22(1), 1-8.

Martín, I. (2007). Retos de la comunicación corporativa en la sociedad del conocimiento [recurso electrónico]: De la gestión de información a la creación de conocimiento organizacional / irene martín Colombia: Red Signo y Pensamiento, 2007.

McDowell, W. S. (2011). "The brand management crisis facing the business of journalism". JMM: The International Journal on Media Management, 13(1), 37-51. doi:10.1080/14241277.2010.545364 
Mora, J. M. (2009). 10 ensayos de comunicación institucional. Pamplona: Eunsa.

Morales-Lugo, F., \& Enrique, A. M. (2007). "La figura del" dircom". su importancia en el modelo de comunicación integral". Anàlisi: Quaderns de Comunicació i Cultura, (35), 83-93.

Porcu, L., Del Barrio, S., \& Kitchen, P. (2012). "How integrated marketing communications (IMC) works? A theoretical review and an analysis of its main drivers and effects". Comunicación y Sociedad, 25(1), 313-348.

The American Marketing Association. (2014). "The american marketing association (AMA)". Retrieved from https://www.ama.org/AboutAMA/Pages/About.aspx

Villafañe, J. (. (Ed.). (2000). El estado de la publicidad y el corporate en españa. Madrid: Pirámide.

Xifra, J. (2005). Planificación estratégica de las relaciones públicas 


\section{IIII \\ Comunicación digital}





\section{Gestión de herramientas 2.0: El caso de la Casa Real}

Dra. Ma Dolores García Fernández

Universidad de Málaga

\section{Resumen}

En los últimos años, la irrupción de las nuevas tecnologías y la aparición de herramientas 2.0 han hecho que las organizaciones tengan que adaptarse a este entorno virtual donde ahora están también sus públicos objetivos. En el caso de las Instituciones Públicas que deben mantener una imagen homogénea y mensajes coherentes y que refuercen la reputación corporativa esta adaptación no resulta tarea fácil.

En el caso de la Casa de SM el Rey, estamos asistiendo a un cambio en los planes estratégicos de comunicación que incluyen la utilización de nuevas herramientas 2.0 como la nueva Web corporativa, o los canales YouTube entre otros. La utilización de estas herramientas modifica a su vez las rutinas comunicacionales del equipo de comunicación de la Casa de SM el Rey, que también han renovado sus sistemas de trabajo. La Casa Real en aras de adaptarse a estos cambios, ha incluido algunas novedades en su comunicación institucional para tratar de conseguir el ansiado entendimiento con sus públicos. 
Palabras clave: Dirección Estratégica de Relaciones Públicas, Comunicación Institucional, Casa Real, herramientas 2.0.

\section{Introducción}

— N la sociedad del siglo XXI en la que nada parece permanente, Eni siquiera las Instituciones Públicas, hace falta cada vez más modelos que colaboren en la transmisión de mensajes coherentes y homogéneos desde las propias Instituciones. Desde los años 90, la comunicación institucional se percibe como un elemento fundamental en la mejora de los flujos comunicativos tanto internos como externos de la Institución con sus públicos. Arrieta (1995: 141142) ya apuntaba que la comunicación institucional es el "sistema nervioso de la institución siendo uno de los objetivos de la misma el concebir y realizar actividades que creen y fomenten la vitalidad y eficiencia de los flujos internos y externos, adecuando el contenido y forma y cuyo fin último es crear, reforzar y modificar entre todo el personal de la organización una actitud positiva en la empresa o institución". En esta misma línea Martín (1998) defendía que el objetivo de esta comunicación institucional es crear una identidad diferenciada, basada en la realidad.

Sin duda, la aparición de Internet ha colaborado en la consecución de estos objetivos y ha supuesto una revolución en las formas de comportarnos y relacionarnos entre los miembros de la comunidad pero más aún, la aparición de las redes sociales y otras herramientas digitales han modificado nuestra forma de interrelación hasta tal punto que "si no estás en las redes no existes". En la actualidad, encontramos que canalizar correctamente esta identidad es fundamental para la supervivencia de la propia Institución. Mientras que anteriormente la comunicación institucional prestaba su atención a los mensajes que producían, se produce desde los años 90 una mayor atención al emisor como canalizador del discurso (Weil: 1992).

Esta vinculación directa entre la interrelación de los miembros de una comunidad virtual y la que podemos llamar real, hace que el movimiento comunicacional que se genera en la red conecte el espacio público a través de lo virtual, como apunta Castell (2012: 23- 
33), "las redes de poder en varios ámbitos de la actividad humana se conectan entre sî". De esta manera, los límites de ambos mundos se difuminan.

Las nuevas herramientas 2.0 utilizadas desde el ámbito institucional se configuran como una mediación entre la Institución y el público o públicos a los que se destina el mensaje comunicativo al igual que ocurre en otros ámbitos de la comunicación organizacional. Estas nuevas herramientas de comunicación aportan nuevos canales que aportan una comunicación más fluida con sus públicos. Marañón (2012: 117-139) señalaba la posibilidad que aportan los nuevos canales como YouTube que se presentan como un nuevo espacio de interacción social con una comunicación directa con los públicos, más interactivo y personal.

En el siglo XXI, la integración de los modelos de comunicación 2.0 por parte de las Instituciones Públicas todavía se perfila de manera incipiente, comienzan a utilizar estas redes sociales entre las herramientas habituales en su comunicación tanto interna como externa y queda por ver cómo se integrarán los modelos tradicionales con los nuevos modelos digitales. Así lo recogen los últimos estudios sobre las tendencias en la investigación en comunicación en España en 2014. (García, M. T., Jiménez, J. L. T., \& Díaz, A. C, 2014: 129 139).

En relación a la Casa de SM el Rey, durante muchos años ha sido una Institución que no había necesitado establecer estrategias comunicativas proactivas, tal y como indican De Pablos y Ardevol (2009: 242), existía una especie de pacto de silencio que denominan «silencio crítico», referido a los actos del rey español y todo lo que concierne a la Familia Real, protegidos de la opinión pública bajo un manto de mutismo. Barredo (2012: 31) habla de "El tabú de la expresividad real" para referirse a esa protección mediática. Tal y como explica Barredo, la alta repercusión de la Institución escogida impide realizar un trabajo de carácter etnográfico, es decir, la observación desde dentro de las rutinas informativas de la Casa de SM el Rey, habiendo pocos estudios al respecto. Pero los acontecimientos ocurridos a raíz del Caso Noos indignaron 
sobremanera a la Opinión Publica y esto hizo que se rompiera ese pacto tácito, unido a algunos desencuentros con la prensa que trataban de coartar la libertad de expresión en relación a la salud del Monarca. Ante esta situación de crisis, la Institución estableció una estrategia de comunicación más proactiva para intentar llegar a sus públicos, utilizando herramientas 2.0 como intento de acercarse a sus públicos. (García: 2014).

Como herramientas 2.0 más destacadas de esta nueva etapa, el 12 de septiembre de 2012 la Casa de SM el Rey lanza una nueva Web corporativa para el público en general y tres meses después lanzó una nueva versión enfocada a su público infantil y juvenil. Por primera vez en la historia de la Monarquía Española, la Institución abre su canal YouTube el 20 de diciembre de 2012 y la red social Twitter el 21 de mayo de 2014. La incorporación de estas herramientas abre nuevos espacios de interacción pero también modifica las rutinas comunicacionales del departamento de comunicación.

\section{Metodología}

La investigación aquí presentada trata describir el impacto de la utilización de estas nuevas herramientas 2.0 en el seno de la Institución de la Casa de SM el Rey. Para ello, hemos analizado cuáles son las herramientas de comunicación 2.0 utilizadas por la Casa de SM el Rey durante los años 2012 a 2014 así como las rutinas de trabajo del departamento de comunicación de la Casa de SM el Rey para analizar cómo afectan la incorporación de estas herramientas en las rutinas de trabajo diario del departamento.

Para la recogida de datos hemos utilizado una ficha de análisis de contenido que incluye los ítems: estructura visual del contenido Web, segmentación de públicos, mensajes transmitidos, y recursos audiovisuales utilizados.

Hemos podido profundizar en el estudio a raíz de la entrevista en profundidad realizadas los días 29 y 30 de agosto de 2013 y el 4 de octubre de 2013.con Director de Comunicación de la Casa de SM el Rey D. Juan Carlos I D. Javier Ayuso Canals, (en adelante Dircom), 
responsable del departamento de Comunicación de la Casa Real y con algunos empleados durante el periodo 2012-2014.

\section{Resultados de la investigación}

En el periodo 2012 al 2014, se incorporan por primera vez en la Institución herramientas 2.0 para la gestión de la comunicación institucional con sus públicos. Estas herramientas son la página Web, segmentada al público infantil por una parte y por otra al público en general, el canal YouTube y una cuenta oficial de Twitter.

\subsection{La nueva página Web de la Institución}

La nueva Web lanzada el 12 de septiembre de 2012, sustituye a la inicial y ofrece frente a la anterior Web, un gran número de recursos gráficos y textuales con fotos inéditas. En total presenta 12.000 fotografías, 3097 discursos y 4509 actividades de la Corona que corresponden a los actos organizados desde el año 2005, año en el que la Casa Real inauguró su primera página. Esta Web corporativa presenta una estructura más clara. El árbol de la Web incluye cinco apartados:

- La Familia Real. Con información bibliográfica de los miembros de la Familia Real. No están incluidos ni Iñaki Urdangarin y el ex marido de la Infanta Elena, Álvaro de Marichalar. Tampoco ninguno de los hijos de éstos a pesar que según el Real Decreto 2917/81 del 27 de noviembre son miembros de la Familia Real.

- Actividades y agenda. En esta apartado se incluyen las últimas actividades realizadas que por cada uno de los miembros de la Familia Real. La agenda está dividido en actividades y viajes oficiales, aunque la recepción de otras autoridades extranjeras, embajadores y relaciones internacionales están incluidos en la lista "actividades". Existe un buscador desde donde se puede filtrar el personaje público, el periodo y la temática, Incluye también un apartado de "vídeos" y "discursos"

- La Corona, hoy. Mantiene en la misma posición el apartado "vídeos" y presenta los apartados "Artículos constitucionales", "las funciones del Jefe de Estado". "El orden de sucesión", 
"Símbolos de Estado".

- Organización y presupuestos. Esta es una de las secciones más ampliadas, incluye el "organigrama y funciones", la organización de la "Casa de SM el Rey", "presupuestos anuales", "normativa" y "contacto". Por primera vez, se publican los presupuestos oficiales otorgados a la Casa de SM el Rey.

- La Monarquía, en la historia. Realiza un pequeño recorrido por la historia de la monarquía desde la edad media a la actualidad, un árbol genealógico desde los Reyes Católicos hasta nuestros días. Incluye información de los llamados "Reales sitios", es decir, aquellos palacios gestionados por Patrimonio Nacional.

Entre las innovaciones técnicas más importantes se encuentran la posibilidad de imprimir directamente desde la Web sin tener que hacer un 'copia pega' en un documento aparte, agilizar el buscador del portal, cambios en la organización de las carpetas y mejora en el diseño de la Web, que permita colocar imágenes de actos anteriores en la página principal. También incluye la opción de poder compartir información oficial en las redes sociales como Tuenti o Twitter. El portal está adaptado a personas con necesidades especiales y así es posible escuchar lo publicado por un sistema de audio especial.

Para el lanzamiento del nuevo portal se eligió una fotografía en la que aparecía las tres generaciones: SM el Rey, SAR el Príncipe y la pequeña Infanta Dña. Sofía, sustituyendo la anterior imagen de portada donde aparecía toda la familia real al completo incluyendo a Iñaki Urdangarin.

SM el Rey en primera persona explica que el nuevo portal se enmarca dentro del "esfuerzo" por mejorar la comunicación externa de la Corona con todos los ciudadanos introduciendo los términos transparencia, rigor e innovación. Para esta comunicación utiliza el formato carta de bienvenida on line. La Institución trata de dar una imagen de entereza frente a los tiempos difíciles que se viven en el año 2012, tratando de relacionarlo con situaciones difíciles vividas en 
el pasado y que tienen con eje vertebrador SM el Rey D. Juan Carlos I.

El léxico utilizado en la nueva página Web institucional está más asociado a términos de empresa que a una Administración Pública o Institucional fruto de la nueva línea comunicacional. Así, vemos en la propia Web casareal.es datos que respaldan esta afirmación, denominando "alta dirección de la Casa" a los anteriormente denominado Jefes de Protocolo y de Relaciones con los Medios". También se refieren a las distintas áreas como "departamentos", término asociado igualmente al mundo empresarial. Estos cambios también están motivados por los cambios comunicativos implantados.

\subsection{La Web dedicada al público infantil}

El doce de diciembre de 2013, la Casa de SM el Rey lanza una nueva sección dedicado a su público inactivo: colegios, institutos, niños y jóvenes en general concretamente de entre seis y catorces años. Para adaptar el mensaje utiliza en un tono didáctico y a través de ilustraciones realizadas por un experto en marketing infantil y gran experiencia en diseño de animación en multinacionales como Warnes Bros, Disney o Cartoon Networks. El objetivo de la versión infantil es explicar las funciones y actividades que desarrolla la Institución en un tono didáctico y teniendo en cuenta el uso de las nuevas tecnologías por parte de este público juvenil y adolescente lanzan una aplicación para smartphones y tabletsiOS y Android.

Otros de los colectivos a los que se dirigen son al público de maestros y profesores. Para ellos, incluyen materiales didácticos para que los profesores, además de dos cuadernillos de actividades destinados los distintos grados de la educación obligatoria (primaria y secundaria) y que pretenden explicar la historia de la Corona en España, quién es la Familia Real y las funciones de la Jefatura del Estado.

La estructura de la Web oficial para el público infantil es similar a la dedicada a los adultos, consta de cinco apartados: Visita guiada al Palacio que incluye una visita virtual por los jardines del Palacio de la 
Zarzuela, la biblioteca o los despachos del Rey, El álbum familiar, actividades, envía tu dibujo, nuestra agenda, vídeos y fotos y material educativo.

\subsection{El Canal YouTube de la Casa Real}

El veinte de diciembre 2012, Casa Real decide incorporarse a las nuevas redes sociales incluyendo un canal oficial de YouTube. Esta incursión en las nuevas tecnologías trata de copiar la utilización de instrumentos 2.0 por parte de otras Casas Reales Europeas como la británica, la noruega, la holandesa y la sueca que ya disponían un canal oficial audiovisual en Internet al servicio de todos los ciudadanos.

El canal YouTube en el momento del lanzamiento se estructura en dos listas de reproducción, una con vídeos de actualidad sobre los actos oficiales de la Familia Real desde el mes de septiembre de 2012 y otra lista con todos los Mensajes de Navidad de S. M. el Rey desde 1975.

La Institución no tenía fondos videográficos propios por lo que en 2010 firman un acuerdo con RTVE y la Agencia EFE para dotar de contenido el canal y la Web a través de los documentos históricos videográficos conservados por éstas. El lanzamiento coincide con los 100 días de funcionamiento de la nueva Web de la Casa Real. El canal YouTube se nutre de los vídeos producidos desde el mes de septiembre de 2012 y otros 140 vídeos institucionales.

Para el lanzamiento se realizó un vídeo interactivo que recogía en 20 minutos, una selección de los Mensajes de Su Majestad el Rey durante las últimas cuatro décadas. Este recorrido histórico condensa más de 400 minutos grabados en 35 años pero dividido por décadas, pudiendo elegir la década que desee visionar. En ese mismo año y con motivo del lanzamiento y por primera vez, se permitió ver en línea el mensaje institucional de Navidad de SM el Rey, que usualmente utilizaba el canal estatal de televisión para mandar su mensaje resumen del año. En este año, además del tradicional mensaje televisivo, añade para sus públicos en la red este mensaje institucional. 


\subsection{La cuenta oficial de Twitter de la Casa de SM el Rey}

La Casa de SM el Rey estrena cuenta oficial de Twitter con el objetivo de informar a los usuarios a tiempo real de las actividades y la agenda diaria de la Familia Real ${ }^{27}$ con un seguimiento inicial el día de su lanzamiento de 51.000 personas $^{28}$, herramienta que implica la comunicación directa en tiempo real con los seguidores de la cuenta y que supone al equipo de trabajo mayor coordinación y destreza en la utilización de estas herramientas así como una capacidad de reacción estratégica ante comentarios negativos mucho mayor que con la utilización de otro tipo de soportes, incrementándose la inversión en herramientas 2.0 que supone un aumento del $40 \%$ con respecto a años anteriores al periodo analizado.

\subsection{La gestión del departamento de comunicación}

El departamento de comunicación de la Casa de SM el Rey está formado por cinco personas, todas ellas de formación académica licenciados en Periodismo y con experiencia profesional en distintos medios de comunicación nacionales. Este equipo se completa con seis personas que desarrollan labores de apoyo de carácter administrativo.

Las funciones del equipo de comunicación en líneas generales es la de ser intermediarios y facilitar la labor de los medios de comunicación y por otra parte colaborar en la organización de los actos públicos organizados por la Jefatura del Estado tanto en el ámbito nacional como internacional, funciones propias de un relaciones públicas.

Diariamente el equipo de comunicación elabora noticias informando sobre los actos oficiales de cada uno de los miembros de la Familia Real que suben a Web institucional. Además, dedican parte del tiempo a la edición de fotografías y vídeos. Todos los días, el equipo de trabajo nutre de contenido la Web corporativa con un resumen de

\footnotetext{
27 Efe. (2014, 21 mayo). La Familia Real se estrena en el uso de Twitter y pide que se utilice un "lenguaje adecuado". www.elmundo.es. Recuperado el 22 de mayo.

2014. http://www.elmundo.es/espana/2014/05/21/537c8234e2704ea6098b456f.html 28 C.V. (2014, 23 de mayo). La Casa Real triunfa en Twitter con 51.000 seguidores en dos días.www.elmundo.es. Recuperado el 24 de mayo de 2014. http://www.elmundo.es/loc/2014/05/23/537df3d4268e3e613d8b4575.html
} 
acto al que acude algún miembro de la Familia Real, fotografía del acto en la que denominan "Agenda de actividades".

Las mismas tareas realizan con el canal YouTube de noticias donde a partir del día del lanzamiento van subiendo fragmentos de los actos en los que participan. Habitualmente el equipo de RTVE y Agencia Efe suelen mandar todos los vídeos realizados y el equipo de comunicación hace una selección de los que pueden utilizar para la página web y el canal YouTube.

El departamento de comunicación cuida mucho que la imagen que se traslade sea del colectivo ya que según el DIRCOM, ellos no son portavoces de la Institución sino SM el Rey y los miembros de la Familia Real. La evolución de la estructura organizativa de la Casa de SM el Rey ha hecho que también el departamento de comunicación haya evolucionado al igual que el resto de las áreas, adaptándose a las distintas estrategias comunicativas y al volumen de trabajo.

Todo esto hace que desde la incorporación de esta nuevas herramientas 2.0, gran parte del trabajo diario consiste en nutrir a la Web de contenidos y actualizaciones, además de informar a los periodistas especializados de los próximos actos públicos de la Familia Real.

La Casa de SM el Rey utiliza estas herramientas 2.0 como el mejor escaparate y la vía para poder comunicar quiénes somos, qué hacemos y para qué lo hacemos y la plataforma Web se convierte en la herramienta vertebradora de la Comunicación Institucional en tanto en cuanto proyecta la imagen institucional y trata de reforzar su reputación corporativa.

\section{Discusión y conclusiones}

En nuestra sociedad actual, la presencia de los medios de comunicación como testigos de los acontecimientos públicos y privados ha hecho que todo acto representativo tenga que ser transmitido a través de los distintos medios de comunicación. No sólo nos referimos a los medios de comunicación de masas tradicionales - prensa, radio y $\mathrm{TV}$ - sino con más atención a los 
nuevos medios de masas, las redes sociales, páginas webs, blogs, canales que se mueven con rapidez y que nos transmiten información, no siempre contrastada y veraz sobre nuestra realidad social.

La Casa de SM el Rey en un intento de acercarse a sus públicos modifica su página Web convirtiéndola en una herramienta de comunicación para llegar a sus públicos objetivos, stakeholders y opinión pública, tratando de establecer una vinculación más directa, cercana y transparente con sus públicos, para ello, ha considerado que el desarrollo de una Web más interactiva, sería un comienzo para tratar de conseguir la aceptación por los públicos.

El alcance en la utilización de estas herramientas 2.0 por parte de los públicos y el impacto real en la modificación y aceptación de la Corona en función de la utilización de estas herramientas está todavía por analizar.

La inclusión en otros campos como Facebook y otras redes profesionales como Linked it o la utilización de blogs corporativos de la Casa Real todavía parecen terrenos lejanos para la Institución hasta el punto de plantearnos si es factible la utilización de todas las herramientas 2.0 para todo tipo de comunicación organizacional teniendo en cuenta que el objetivo principal de la Institución es permanecer y reforzar su reputación.

En el lanzamiento de la Web corporativa se observan algunos fallos de tipo comunicacional como salas de prensa virtuales sin contenido y sin sistematización en la subida de los mismos, provocado a su vez por la vorágine informativa sobre la Casa de SM el Rey en los últimos años que imposibilita al equipo tener unos objetivos diarios claros y orientados.

La creación de un banco de imágenes y vídeos propios, así como una hemeroteca formada por material audiovisual propio hará a la Institución depender en menor modo de enlaces externos y el desarrollo de una Web más interactiva permitirá efectivamente la posibilidad de establecer una comunicación con la Institución, siempre considerada como inaccesible. 
Por todo ello, se perfila una necesidad directa de un profesional que conozca en profundidad la relación con los medios y que conozca la dinámica organizativa y funcional del equipo organizador de un acto, un experto en protocolo, en definitiva un relaciones públicas que domine a su vez el manejo de las nuevas herramientas 2.0.

Esto hace que al igual que en ámbito de la empresa, la adaptación a las rutinas de trabajo en la comunicación institucional que supone la utilización de las nuevas tecnologías y redes sociales haya modificado las rutinas diarias de trabajo y la gestión sea más compleja al generarse un aumento de la producción de información y el control de nuevos canales que hay que gestionar de manera profesional.

\section{Referencias}

Arrieta Erdozain, L. (1990). La dimensión del propósito en la comunicación organizacional. México: Grupo editorial Iberoamérica.

Barredo, D. (2012) El tabú de la expresividad real. Análisis del tratamiento informativo del Rey Juan Carlos I en abc.es y elpais.es (20092011).Tesis doctoral. Universidad de Málaga.

Castells, M. (2012). Redes de indignación y esperanza: los movimientos sociales en la era de Internet. Madrid: Alianza Editorial. (p. 294).

De Pablos Coello, J.M. y Ardevol Abreu, A. (2009): "Prensa española y monarquia: "el silencio crítico" se termina. Estudio de caso". Barcelona, UAB. Anàlisi (237-253).

García Fernández, M.D. (2014). Comunicación y Casa Real. La organización de actos como estrategia de Relaciones Públicas de la casa de SM el Rey. Tesis doctoral no publicada. Universidad de Málaga.

García, M. T., Jiménez, J. L. T., \& Díaz, A. C. (2014). "La investigación en comunicación en España: estado de la cuestión”. Revista de la Asociación Española de Investigadores en Comunicación, 1(01).

Martín Martín, F. (1998): Comunicación empresarial e institucional. Madrid: Ed. Universitas SA.

Olivia Marañón, C. (2012): “Comunicación 2.0, visibilidad e interactividad y fundamentos de la imagen corporativa de las 
Universidades públicas de Madrid en YouTube". Fonseca, Journal of Communications, ISSN-e 2172-9077, No . 5 , Págs. 117-139.

Weil, P. (1992): La comunicación global, comunicación institucional y de gestión. $2^{\mathrm{a}}$ ed. Barcelona: Ed. Paidós.

Página oficial Casa SM el Rey www.casareal.es

Canal oficial Youtube:

https://www.YouTube.com/user/casarealtv/featured

Twitter Casa de SM el Rey https://twitter.com/casareal 



\section{La comunicación lúdica: nuevos mecanismos de atracción}

Enrique Morales Corral

Associate Professor U-TAD UCJC

\section{Resumen}

La comunicación nunca ha estado tan presente en la historia como en la actualidad. Las nuevas tecnologías, y sobre todo Internet, han facilitado mucho esta tarea. Nuevas formas de comunicación están adquiriendo importancia dentro del espectro conocido. La comunicación lúdica es una de ellas, y empieza a desarrollarse y adquirir importancia. Será uno de los factores que guíen el futuro, como respuesta a una serie de necesidades creadas por las generaciones más jóvenes, debido a la introducción decisiva de los videojuegos como forma de ocio masiva, que propiciaran un cambio en la forma de entender la comunicación del futuro.

Dentro de estos métodos destaca sobre todo el de gamificación, que ya está cambiando algunos procesos organizacionales. Se explicará y se mostrará su influencia como mecanismo integrador y socializador de estructuras que durante mucho tiempo han permanecido rígidas, empezando a superar todas las expectativas que sobre ella se tenían.

Palabras clave: comunicación lúdica, gamificación, videojuegos, sociología organizacional, interactividad, TICs. 


\section{Elementos lúdicos: ¿qué es el juego realmente?}

— L juego, según Neumann es un conjunto de reglas que definen una experiencia lúdica (Neumann, 1953: 46). Para Huizinga (1987) presenta una serie de rasgos distintivos: la libertad de acción, lo límites de espacio y tiempo, unas reglas obligatorias y genera la conciencia de vivir en una realidad paralela. Este autor asentó las bases con su libro Homo ludens de lo que hoy se puede considerar como la teoría del juego como práctica social moderna.

Otra interesante definición de juego es: un sistema con el que pueden interactuar uno o más jugadores para conseguir resolver un estado de desequilibrio que implica la lucha por un objetivo (López Barinaga, 2010: 22).

Al dar el paso al mundo digital tenemos que hablar ya de videojuegos, y es necesario hablar de la relación hombre-máquina, y de la visión de McLuhan (1964), porque prolonga al ser humano y sus capacidades, ayudándole en sus tareas diarias. Y el juego no iba a ser menos. Este autor defiende lo atractivo que supone para el ser humano la tecnología, como una necesidad continua inacabada, ya que lo que hoy es lo último mañana no lo será. Es una carrera sin fin, en la que la renovación de nuestros equipos electrónicos es la base de toda una estructura comercial muy definida y estudiada.

Durante mucho tiempo hemos oído a nuestros mayores que jugar no es algo serio. No es propio de adultos. O, ¿si lo es? La sociedad está cambiando, y jugar, sobre todo cuando hay presente una pantalla, está convirtiéndose en algo habitual, incluso en gente mayor, que no ha crecido practicando con un ordenador o con videojuegos. Ya no es algo sólo de niños y de adolescentes, es una práctica social cada vez más aceptada que tiene enganchados a millones de personas en todo el mundo, y que ha incorporado una serie de rutinas sociales. Pero, ¿a qué se debe este cambio de perspectiva? ¿Qué ha propiciado esta evolución en el sentir colectivo?

Este capítulo pretende mostrar cómo es la comunicación lúdica, situándola como un nuevo proceso social en las últimas décadas. Se 
mostrará una evolución en la percepción social de este proceso, sobre todo en los últimos quince años, pero para ello mostraremos los inicios del concepto en los próximos epígrafes, que nos sirva de base sobre la que construir la nueva visión que proponemos.

\section{Los inicios del concepto}

A la hora de referenciar la sociología de la cultura para Bourdieu, hay que tener en cuenta la necesidad de este autor de intentar explicar siempre las relaciones y las diferencias sociales en sus trabajos. El desarrollo de sus estudios sobre la cultura se encuentra impregnado de la necesidad de explicar los comportamientos transversales que las clases sociales presentan ante los estímulos culturales a los que son sometidos. Esto supone un impulso necesario que evita caer en determinismos metodológicos y utilizar un sentido positivista de la investigación social, a veces olvidada por numerosos investigadores. Aborda los temas centrales de la desigualdad a la hora de distribuir el poder entre la población, sobre todo el poder simbólico (aquel que consigue la atracción de las masas), que ostentan las élites desde tiempos inmemoriales, sobre todo las económicas. Este tema siempre ha estado muy presente, pero ahora con la crisis social, de valores y económica que estamos viviendo, vuelve a ponerse de rabiosa actualidad.

La figura de Bourdieu arrastra la comprensión de ver reflejada en sus obras la inquietud que sobre el consumo siempre ha rodeado a las teorías clásicas marxistas que rodeaban el tema, sin profundizar en el origen y desarrollo de este efecto económico (Bourdieu, 1990). Bourdieu, sin embargo, lo considera central y reconoce este defecto de origen en esta corriente, intentando mostrar y crear toda una revisión conjunta que influye decisivamente.

Michel Foucault también supone un pilar básico. Los estudios en los que abandona los debates marxistas para centrarse en las relaciones de poder sobre la cultura, han propiciado una amplitud en el punto de mira de muchos investigadores. Foucault investiga, entre otras cuestiones, las relaciones de poder que se establecen en las redes sociales y sus cambios. El propio autor reconoce la gran dificultad de estos estudios, porque no existen patrones de comportamiento de 
poder rígidos, sino que son variables en función del órgano a controlar. Es en este punto en el que enlazamos el estudio de la comunicación lúdica, como elemento transversal que está rellenando gran parte de las olvidadas renovaciones clásicas, que las nuevas generaciones no están dispuestas a utilizar.

La Escuela de Frankfurt estudió con profundidad lo que denominaba la industria de la cultura, en la que incluían industrias como el cine, la televisión, la música, la radio, los periódicos... Señalaban que su expansión, por medio de productos poco exigentes e iguales para todos, socava la capacidad que tienen los individuos para desarrollar una forma de pensar crítica e independiente. El arte desaparece, en cierta manera, por la comercialización. Hay una cierta perversión económica en el arte que sustituye el ideal romántico de crear: el arte por el arte.

Habermas retomó algunos de estos temas, pero los desarrolló de forma diferente. Analizó el desarrollo de los medios de comunicación desde comienzos del siglo XVIII hasta la actualidad, rastreando la aparición y posterior decadencia de la esfera pública, que es un área de debate público en el que se discuten cuestiones de interés general y se forman opiniones. Para Habermas, el surgimiento de la esfera pública burguesa fue facilitado por otros dos hechos que juegan un papel clave (Habermas, 2003): el desarrollo de la prensa periódica y el desarrollo de una variedad de nuevos centros de sociabilidad en los pueblos y ciudades de inicios de la Europa moderna. Estos centros incluían los salones y las casas de café, que, desde aproximadamente mediados del siglo XVII, se convirtieron en lugares de discusión y ambiente, en los que las élites instruidas podían interactuar entre sí y con la nobleza en un mismo plano, más o menos, de igualdad.

Se produjo la creación de una constante construcción de una realidad debatida por todo aquel lo suficientemente informado u osado como participar en la discusión. A modo de foro romano, las opiniones se sucedían, argumentando, con datos y noticias, los más disparatados e importantes temas, desde una guerra hasta el color favorito de las señoritas para la primavera que comenzaba. Lógicamente, el debate 
político fue uno de los principales temas por su gran importancia institucional.

La esfera pública, al menos en principio, implica que los individuos se reúnen como iguales en un foro de debate público. Sin embargo, llega a la conclusión de que lo que prometía este desarrollo temprano de la esfera pública no se ha cumplido del todo. El debate democrático en las sociedades modernas está ahogado por la industria de la cultura. La opinión pública no se configura mediante debates abiertos y racionales como al principio, sino a través de la manipulación y del control, como sucede en publicidad.

La comercialización de los medios de comunicación alteró su carácter en un sentido fundamental: aquello que antes fue un fórum ejemplar del debate racional-crítico se convirtió tan sólo en otro campo de consumo cultural, y la esfera pública burguesa en un mundo simulado de creación de imagen y de manejo de la opinión, en el que la difusión de los productos de los medios de comunicación se pone al servicio de intereses creados (Thompson, 1997). El principio crítico de la publicidad es el concepto nuclear de una teoría de la democracia y de la formación democrática de la voluntad.

A finales del siglo pasado se popularizó Internet y recogió el testigo del fórum planetario, en el que las clases sociales se desvanecían entre los teclados y todos tenían su pequeño altavoz al mundo. Los órganos de poder tradicionales siguen manteniendo su dominio hegemónico, pero lo que si es cierto, es que cada vez hay más opciones comunicativas y muchos ciudadanos buscan alternativas, sobre todo los jóvenes que ven en las redes sociales su válvula de escape mediática.

\section{La cultura y la comunicación de masas}

La sociedad de masas crea su propia cultura y su propia comunicación. Desde la aparición de la imprenta hasta hoy, se ha producido un incremento en el número y velocidad de las comunicaciones a través de nuevos y sofisticados avances tecnológicos (Moragas, 1985). Ello ha dado lugar a la creación de todo un paradigma sobre la comunicación como base. Esta cultura de 
masas sería la consecuencia de la transformación de la comunicación cara a cara y a pequeña escala hacia las comunicaciones impersonales. Esta cultura debería estar caracterizada por el acritismo, la degradación de contenidos, la manipulación de las mentes y otra serie de características.

Autores pertenecientes a la Escuela de Frankfurt, como H. Marcuse, Th. Adorno o J. Habermas, han sido particularmente críticos con algunos elementos de la cultura de masas. Sin embargo, existe una creciente tendencia a analizar rigurosamente los efectos de dichos medios de comunicación, lo cual no muestra exactamente ese panorama en la llamada cultura de masas. Se puede constatar con certeza suficiente que la cultura de masas, vinculada a las comunicaciones y a otros elementos, contiene elementos nuevos y positivos frente a culturas históricas anteriores: un incremento de la información, una ampliación de las audiencias en industrias culturales, y nuevos mecanismos de acercamiento de la tecnología de la comunicación a nuevos targets económicos.

Tradicionalmente, la comunicación de masas suele asociarse únicamente con el entretenimiento y, por tanto, se la considera algo bastante marginal en la vida de la mayoría de las personas. Sin embargo, ésta es una visión parcial, ya que la comunicación de masas también tiene que ver con otros muchos aspectos de nuestra actividad social. Medios como los periódicos o la televisión tienen una gran influencia en nuestras experiencias y en la opinión pública. No sólo porque influyan de una determinada manera en nuestras actitudes, sino porque son los medios para acceder al conocimiento del que dependen muchas actividades sociales. Los jóvenes buscan ya otros mecanismos comunicativos, los nuevos medios tendrán que reinventarse si quieren seguir siendo importantes. En este sentido, la introducción de mecanismos lúdicos puede facilitar captar la atención de toda una generación, acostumbrada a nuevos mecanismos comunicativos, con especial mención al mundo de los videojuegos. 


\section{Huizinga y su Homo ludens \\ 4.1. El juego es una característica de la especie humana}

Los historiadores del juego como herramienta didáctica, como Huizinga, han mostrado la normalización de las actividades lúdicas en todas las culturas y en todos los rincones del planeta sin importar los niveles de desarrollo o cognitivo. No sólo es una actividad universal sino que es posible encontrar el mismo juego en diferentes culturas. Incluso el autor describe la necesidad de crear el término Homoludens (Huizinga, 1987: 7), hombre que juega, como forma de valorar la actividad del juego en los procesos de aprendizaje y desarrollo del ser humano. Se trata de entender el juego como fenómeno cultural y no sólo como una función biológica. El autor, a partir de su célebre ensayo de 1938, recorre las deficiencias que, desde la etnología y las ciencias en general, han otorgado a la importancia del concepto juego en sus estudios sobre el comportamiento humano.

¿Pero dónde está el origen biológico del juego como actividad? El autor sintetiza varias posibilidades como maneras de dar significación al juego: por un lado el juego posee una finalidad útil en el desarrollo de alguna actividad (descarga de exceso de energía vital, impulso de imitación, relajamiento, preparación para actividades futuras a modo de entrenamiento...) y por otro lado el juego se presenta como una función social, entender al juego en su concepción primaria como elemento relacional, es decir, mostrar las competencias de relación entre seres humanos a través de la interacción. De hecho, ambas categorías están unidas por un sentimiento de pertenencia conjunta, personificado en el concepto que el autor define en su término inglés fun (diversión), debido a que es fundamental este móvil integrador como impulso al fenómeno descrito. Es en este punto donde radica el secreto del juego como proceso biológico, porque explica su uso como proceso tanto en humanos como en animales. De hecho, por su carácter irracional innato, supone una de las expresiones primarias más convergentes que ambos mundos pueden llegar a compartir, reduciendo su práctica a instintos primarios.

Huizinga establece un hábil símil al tratar de explicar cómo las grandes ocupaciones primordiales de la convivencia humana están 
impregnadas por el juego. Hace referencia al lenguaje como ejemplo perfecto de la construcción humana de un instrumento en torno al juego. Establece que tras cada expresión de algo abstracto hay metáforas, y tras ellas juegos de palabras, lo que muestra este proceso como innato en todo proceso comunicativo. Se intenta romper con la creencia popular de que el juego es algo opuesto a lo serio, como expresión estructural fiable de nuestra razón. El autor huye constantemente de esta percepción, que para él es falsa, debido a su injusta concepción relativa. Admite que el juego no está socialmente considerado como una actividad seria en general. Sin embargo, hay juegos que por su carácter, basado en la tradición, si son considerados actividades serias y profundas. Un ejemplo es el ajedrez (García, 1998), que incluso está reconocido como deporte por la inmensa mayoría de la población.

\subsection{La relación entre el juego y la cultura}

Esta relación permite al autor centrarse en los juegos de índole social como estructura preferencial a la hora de describir los procesos esenciales de dicha conexión. Para Huizinga:

"Todo juego es, antes que nada, una actividad libre. El juego por mandato no es juego, todo lo más es una réplica, por encargo, de un juego. (...) El ser vivo que juega encuentra gusto en ello, y en ello consiste precisamente su libertad" (Huizinga, 1987: 20).

Esta visión enlaza perfectamente con la infancia y la imagen de un niño o cachorro jugando como parte de su instinto de aprendizaje. De hecho, podemos llegar a cuestionar la supuesta libertad del juego ya que: ¿hasta qué punto el instinto es libre? ¿No responde más a mandatos genéticos-sociales aprendidos por imitación? La verdadera libertad en el juego llega con la edad adulta, en la que sólo se juega en el tiempo libre, porque en el trabajo diario difícilmente podremos encontrar esta práctica. Pero el juego en la edad adulta presenta aspectos socialmente comprometidos que en el caso concreto del videojuego encuentra un proceso claramente manipulado, porque ha tenido hasta fechas muy recientes el cartel de matamarcianos $\mathrm{o}$ 
producto sólo utilizado por niños y jóvenes, siendo hoy en día su uso mucho más naturalizado y extendido entre la población.

El humano adulto necesita del juego tanto o más que los niños, porque supone un proceso continuo en su proceso natural de interacción con los entornos, tanto sociales como personales. No tiene ningún sentido pensar que el juego es algo propio de niños, como muchas corrientes didácticas defienden, afortunadamente cada día menos. No podemos olvidar, de repente, uno de nuestros mejores mecanismos de interacción, por ser algo propio sólo de la infancia. ¿Acaso no seguimos jugando a cartas, ajedrez y dominó siendo adultos? La aceptación de estos juegos entre la población adulta se basa en la tradición, en la normalización de estos hábitos como naturales y en unas connotaciones más sociales que el juego infantil o juvenil. En éstos hay aspectos más dominantes, como la exploración, el desarrollo viso-motor... aunque el aspecto social también desempeña una importante labor socializadora. Quizá el espectro social sea uno de los aspectos importantes que marca la estructura creada en torno al uso del juego en una u otra etapa de la vida.

La connotación negativa de otros juegos responde a temores infundados, creados a partir de estructuras tan opacas como son las del deber y la tarea, que menosprecian este proceso por ser habitualmente infantil. El valor intrínseco del concepto como elemento divertido supone también otro de los aspectos fundamentales en la construcción negativa del desarrollo. Estos dos procesos son, sin duda, los que han alimentado la raíz negativa que ha invadido al videojuego casi desde sus inicios, y que, a día de hoy, todavía pervive en una gran parte de la sociedad, sobre todo de edad avanzada, que no entiende ni entenderá como hombres y mujeres adultos encuentran divertido jugar a videojuegos. Es un mecanismo de juego reciente, de no más de cuarenta años, que nació como un producto orientado al público infantil y juvenil, pero que hoy en día ha evolucionado y existen productos para todas las edades y gustos.

Huizinga incluso va más allá, y establece una tercera manera de dar significación al juego. Lo hace a partir de la solidificación como estructura cultural. Al terminar cualquier juego permanece en la 
memoria de los que han participado, creando un recuerdo o tradición que puede ser recreado en cualquier otro momento, dotándole de la mencionada estructura cultural.

\subsection{La competición en el juego}

Ya desde las máquinas recreativas (alojadas en salones al uso) se permitía poner el nombre o siglas de las mejores puntuaciones para poder demostrar los logros alcanzados. Esta labor pública es hoy en día parte fundamental de todo el juego online, y continuará creciendo. Es una parte más del reto que supone seguir las reglas marcadas por los desarrolladores, con el fin de ganar, meter gol o matar a todos los enemigos. Podríamos hablar incluso de una personificación de los resultados como trofeos reales para una gran parte de los jugadores de videojuegos, que hablan de sus proezas como lo hacían antaño los cazadores o los grandes conquistadores. La necesidad de exhibir los logros logrados se potenciará cada día más, siendo ya hoy en día normal, que muchos videojuegos permitan exhibir los resultados obtenidos en nuestras redes sociales favoritas.

Un nuevo deportista está por llegar: los ciberatletas, aquellos que se dedican profesionalmente a jugar a videojuegos en torneos y exhibiciones. Esta práctica todavía no es muy común en Europa, y menos todavía en España, pero en otros países es ya algo normal, como en Corea del Sur. En el año 2000 comenzaron a celebrarse los World Cyber Games, el mayor evento internacional de deportes electrónicos en Corea del Sur, inspirado en los Juegos Olímpicos, cambiando de país desde el 2004, llegándose a celebrar ya en EEUU, Italia, Alemania, China y Singapur. Cada año aumenta su presencia en los medios especializados, superando el millón de visitas en los últimos años.

Es solo cuestión de tiempo que este nuevo deporte llegue a nuestro televisor o pantallas del hogar, convirtiéndose en algo masivo y no sólo para minorías como hasta ahora, demostrando que los videojuegos pueden trasvasar incluso la barrera del ocio para convertirse en todo un deporte, como el ajedrez. Huizinga ratifica esto mostrando como: "el carácter lúdico puede ser propio de la acción más sublime” (Huizinga, 1987: 34), porque la sola realización 
del juego puede demostrar una representación cultural propia equiparable a cualquier otra actividad de representación. En este sentido, hablamos de una espectacularización del juego. En cada país existen unos pocos deportes que acaparan las noticias, convirtiéndose en todo un fenómeno de masas, atrayendo la atención de los medios de comunicación y siendo reclamo como estructuras publicitarias de todo tipo. Se trata de mercantilizar el juego en sí, creando ídolos y personificando los valores del esfuerzo y del talento, con el único fin de explotar sus capacidades comerciales.

Otro de los aspectos importantes para el autor es que el juego crea orden porque está sujeto a unas reglas. Esto supone una normalización del proceso que eleva su realidad nuevamente a la categoría de estructura. No hay elementos que pongan en duda esta sentencia de Huizinga. Sostiene que la esencia de la propia cultura parte del juego como elemento fundamental en su esencia, debido sobre todo a su carácter social e interactivo. Supone una nueva forma de comunicación y avance en las diferentes realidades comunicativas de los seres humanos. El potencial demostrado por este tipo de prácticas supone hoy en día un nuevo campo de estudio, en el que los videojuegos presentan su principal baza, debido a su gran penetración social y a su alta conexión online, que puede facilitar en gran medida la obtención de datos válidos.

\section{5. ¿Pero qué es la comunicación lúdica?}

Después de la explicación de cómo el juego se ha ido imponiendo en la cultura y en las relaciones humanas, es necesario centrar el tema, mostrando el proceso en el que la comunicación está introduciendo cada vez más elementos lúdicos, como forma de atracción, y cómo reformulación de sus propias estrategias. Una de las principales causas de este nuevo proceso es el auge de los videojuegos, que han cosechado legiones de fans en todos los rincones del planeta, naturalizando su uso entre la población de todas la edades y clases sociales.

El proceso hacia su uso masivo ha sido evidente, sobre todo a partir del 2006, con la aparición de la videoconsola Wii de Nintendo que popularizó y acercó este mundo a usuarios que nunca antes habían 
pensado en jugar a videojuegos (Morales, 2011). La imagen de abuelos jugando a videojuegos con sus nietos comenzó a hacerse normal. Actualmente las pantallas táctiles en smartphones y tablets están popularizando aún más si cabe este fenómeno, acumulando millones de usuarios (Morales, 2012).

Es una industria cultural que ha sido un potente laboratorio multimedia en la introducción de nuevos mecanismos de distribución online. No olvidemos que los videojuegos son software y su venta tiende cada día más hacia un mercado basado en la distribución online, abandonando el tradicional modelo retail o en caja, siendo uno de los primeros en popularizar y explotar este tipo de distribución. Vemos en el gráfico 1 las previsiones que se hacen sólo para este modelo de distribución, con crecimientos espectaculares.

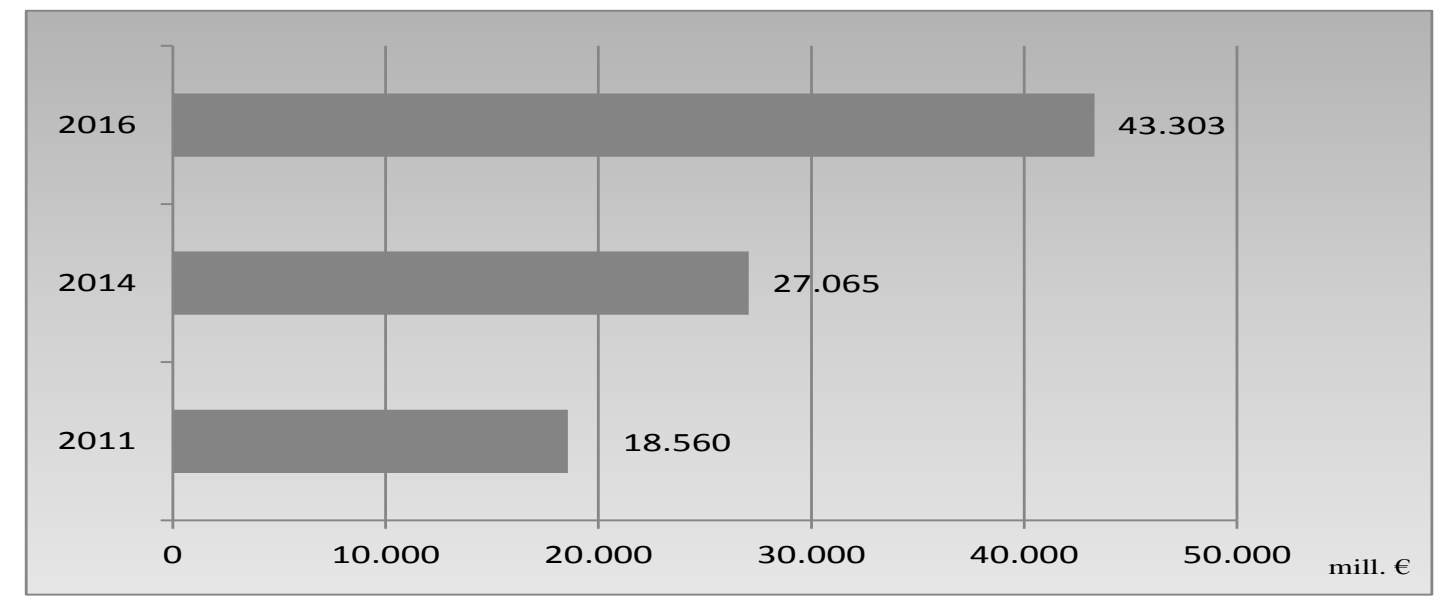

Gráfico 1: Previsiones del mercado mundial de venta digital en videojuegos. Fuente: elaboración propia a partir de datos consultora Ovum

Es sólo cuestión de tiempo la introducción masiva de compañías de videojuegos en proyectos cinematográficos de sus sagas más reconocidas. De hecho la saga Resistent Evil de Capcom va ya por su quinta película y en los próximos años se esperan el debut cinematográfico de sagas reconocidas como: Assassin's Creed, Splinter Cell, God of War, Deus Ex, Mass Effect, Castlevania, Metal Gear Solid... la lista es larga de proyectos confirmados. Se producirán productos transmedia, aprovechando la esencia de un producto para otros formatos: cine, películas, cómics, libros... Las capacidades de 
los grupos multimedia abarcarán nuevas vías de ingresos rentabilizando todavía más las franquicias más famosas.

¿Y a dónde nos lleva todo esto? A una moda comunicativa lúdica que impregna ya gran parte de los procesos en las organizaciones, y que veremos un ejemplo concreto en el siguiente epígrafe.

\section{Gamificación: un proceso organizacional lúdico}

El término gamificación ha dejado de ser algo desconocido en los últimos meses para muchos empresarios. Es un término que está de moda (burzword) y que llena gran parte de las conferencias de eventos patrocinados por todo tipo de consultoras, bancos o aseguradoras.

Una primera definición sencilla de gamification, ludificación, jueguización, juguetización o la traducción española del primer término: gamificación, sería el uso de elementos propios del juego en el mundo real, en actividades no recreativas (Deterding, S., Dixon, D., Khaled, R., Nacke, L., 2011).

Si profundizamos un poco más podríamos añadir que consiste en aplicar dinámicas y mecánicas propias del juego en el ámbito corporativo organizacional para conseguir objetivos concretos como: aumentar la productividad, la fidelización de empleados o clientes, mejorar el ambiente de trabajo...

El objetivo básico es convertir una actividad a priori aburrida o rutinaria en algo motivante, en un desafío, consiguiendo una mayor implicación de los implicados y mejores resultados en el objetivo final. Es un mecanismo que potencia la motivación interna del trabajador o del equipo de trabajo, y la motivación externa, mediante la participación de los usuarios, consiguiendo una mejor eficiencia en sus tareas asignadas.

En la tabla 1 podemos observar una serie de procesos internos y externos que pueden ser desarrollados mediante técnicas de gamificación. 


\begin{tabular}{|c|c|}
\hline \multicolumn{2}{|c|}{ Tabla 1: Motivación interna y externa en procesos de gamificación } \\
\hline Motivación interna & Motivación externa \\
\hline Aprender & Participación activa \\
\hline Ganas de mejorar & $\begin{array}{c}\text { Integración en procesos } \\
\text { corporativos }\end{array}$ \\
\hline Deseo de superar obstáculos & Recompensas e incentivos \\
\hline Ganar & Desafíos \\
\hline Recompensa por actividades sociales & Reconocimiento público \\
\hline
\end{tabular}

\section{Fuente: elaboración propia}

Para que tenga éxito esta técnica es fundamental que esté muy adaptada al tipo de tarea y al tipo de persona que se pretende motivar. No hay una receta básica aplicable para todos los trabajadores o para cada tarea y situación, se debe personalizar mediante un mecanismo básico de consultoría específico. Este aspecto es básico, ya que se han dado malas implantaciones de estas técnicas en más de un proceso por no adecuarlas correctamente al contexto determinado.

Algunos ejemplos básicos de objetivos o tareas susceptibles de potenciarse o mejorarse mediante el uso de gamificación los podemos ver en la tabla 2:

\begin{tabular}{|ll|}
\hline \multicolumn{2}{|l|}{ Tabla 2: Ejemplos de tareas susceptibles de gamificación } \\
\hline 1. & Cumplimentar todo tipo de tareas administrativas \\
\hline $\begin{array}{l}\text { 2. } \\
\text { competencia }\end{array}$ \\
\hline 3. & Interacción con los clientes \\
\hline 4. & Adquisición de nuevas habilidades \\
\hline 5. & Mejorar las relaciones laborales con los compañeros \\
\hline 6. & Incentivos \\
\hline 7. & Conocimiento de la marca o el producto de la empresa \\
\hline 8. & Cumplir los objetivos básicos de cada puesto laboral \\
\hline 9. & Entregar a tiempo las tareas o proyectos asignados \\
\hline 10. & Autoevaluación laboral \\
\hline 11. & Motivación del esfuerzo \\
\hline 12. & Fidelización de la marca o la empresa \\
\hline 13. & Favorecer la concentración personal \\
\hline
\end{tabular}

Fuente: elaboración propia

Como acabamos de ver la gamificación es más que solamente implantar mecanismos de juegos en procesos de producción o de tipo 
empresarial, es un mecanismo integrador de estrategias con medios, estructuras y fines concretos, muy adaptados al entorno y a la situación particular de cada implantación. De hecho podríamos hablar de tres tipos básicos de gamificación (Vargas-Machuca, 2013):

1. Interna: son aquellas enfocadas fundamentalmente a los departamentos de recursos humanos porque buscan la mejora de la motivación, la productividad...

2. Externa: son aquellas enfocadas al marketing, ventas, conocimiento de la marca o los productos...

3. Cognitiva: son aquellas se utilizan para modificar comportamientos o actitudes sociales a favor de una causa social o un objetivo concreto.

Gamificación no es poner a los empleados a jugar, o introducir juegos de mesa o videojuegos en las salas de descanso, eso es facilitar la desconexión de aquellos empleados aficionados a esos hobbies, o en el peor de los casos distraer de la tarea básica por la que están contratados. No es tampoco utilizar mecanismos de juego sobre un problema para buscar, por ejemplo, un aumento de compromiso de usuarios como resultado. Se trata, como hemos explicado en este punto, de una experiencia más integradora y más personalizada que debe de ser supervisada por un consultor cualificado que detecte y proponga soluciones adaptadas a cada lugar, tarea u objetivo susceptible de ser gamificado.

Algunos autores sitúan el origen del término en el año 2002 en círculos académicos y de investigación. No sería hasta el 2007 o 2008 cuando el término empezó a tener relevancia mediática. La popularización decisiva no se produciría hasta principios del 2010 y su entrada como palabra clave en las búsquedas de Google hasta finales del mismo año.

En el gráfico 2 vemos cómo ha ido creciendo progresivamente el número de búsquedas del término Gamification en el mundo desde enero del 2011 a octubre del 2014. Para ello hemos utilizado la herramienta gratuita Google Trends que nos permite ver en forma de 
gráfico la popularidad de un término, personaje o noticia concreta a lo largo del tiempo y en diferentes partes del planeta, utilizando el número de búsquedas de Google como unidad básica de análisis, comparadas con el número total de búsquedas realizadas. La aplicación no ofrece el número de búsquedas en concreto, sino la trayectoria longitudinal de las mismas, mostrando si ha aumentado o no su popularidad a lo largo del tiempo, pudiendo afinar bastante en las búsquedas mediante opciones específicas de meses, años, y países.

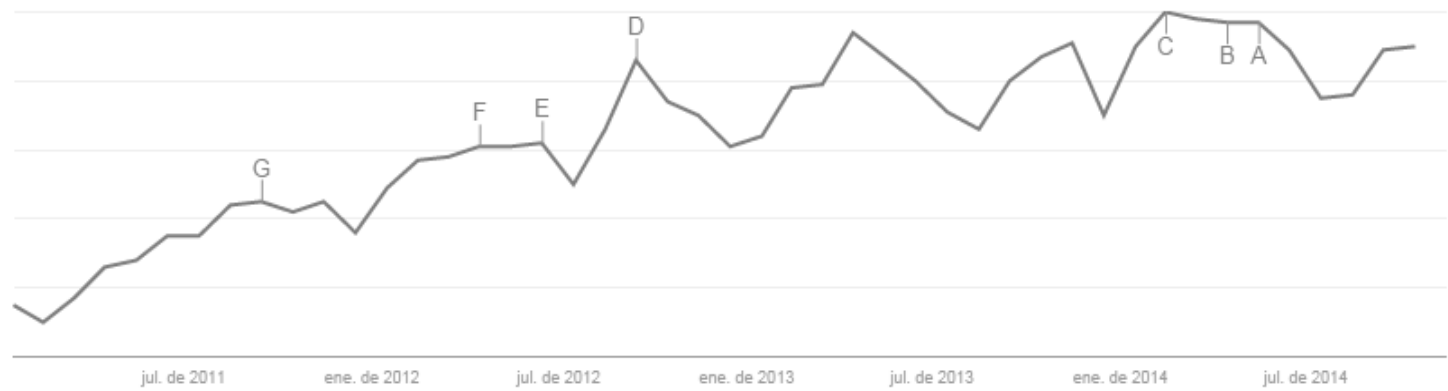

Gráfico 2: Tendencia de popularidad a nivel mundial del término Gamification desde Enero 2011 a Octubre 2014. Fuente: Google Trends

Las letras del gráfico representan artículos, noticias o informes de gran interés mediático indexadas por Google que intentan justificar los picos de búsquedas sobre el término solicitado. Nos llama la atención el pico representado por la letra $\mathrm{D}$, que representa un estudio de la web MarketWatch, especializada en información financiera sobre el uso de estrategias de Gamification en el entorno empresarial de la consultora Bunchball (2012), líder en este sector, presentando la investigación: The Gamification of Consumer Engagement, que supuso un importante aumento en el número de consultas en Google debido a su impacto.

\section{Conclusiones}

Este capítulo ha intentado explicar una nueva tendencia que se está desarrollando en la actualidad: la incorporación progresiva de elementos lúdicos en los mecanismos de comunicación. Se ha intentado situar el concepto en diferentes procesos teóricos históricos, para dotar de marco conceptual adecuado al proceso. 
Esta introducción está motivada en gran medida por un cambio social evidente, propiciado fundamentalmente por los videojuegos como elemento de ocio masivo en la actualidad. Millones de ciudadanos se están acostumbrando a su uso y a sus mecánicas, lo que facilitará en el futuro cercano nuevos mecanismos con los que refundar diversos aspectos comunicativos, como son la publicidad o la comunicación organizacional, entre otros.

La popularización de los dispositivos de comunicación móviles, sobre todo los smartphones y los tablets, ha sido también decisiva, pudiendo masificar el videojuego como ocio "en tiempos perdidos": esperando el autobús, almorzando..., mediante juegos sencillos, directos y con una pequeña dosis de enganche. Por todos es sabido el éxito de videojuegos como Angry Birds o Candy Crush, jugados por millones de usuarios en todo el mundo, de todas las condiciones sociales, económicas y culturales.

Una nueva comunicación está llegando a la Sociedad Red de Castells (2006), en la que se desarrollará de manera natural, propiciando nuevamente cambios sociales en función de los valores e intereses dominantes en cada proceso. El Informacionalismo se potenciará con nuevos mecanismos, uno de ellos puede ser el descrito en este capítulo, participando activamente y en colaboración con la conexión que la red de redes nos permite.

La gamificación es ya un proceso de moda, pero todavía no muy conocido para el gran público. Es sólo cuestión de tiempo que este tipo de dinámicas se popularicen y den el salto de las organizaciones a aspectos más cotidianos, participando en nuestro día a día, como elementos comunicativos.

\section{Referencias}

Bourdieu, P. (1990) Sociología y cultura. México.Ed. Grijalbo.

Bunchball (2012) The Gamification of Consumer Engagement. [Disponible a 18-03-2015 en: http://goo.gl/xTZqjR].

Castells, M (2006) La era de la Información (vol. 3): Economia, sociedady cultura. Fin de milenio. Ed. Alianza. 
Deterding, S. Dixon, D. Khaled, R. Nascke, L. (2011) From game design elements to gamefulness: Defining Gamification. Proceedings of MindTrek.

Habermas, J. (2003) Teoría de la acción comunicativa. Vol. i-ii. Ed. Taurus. Huizinga, J (1987) Homo ludens. Ed. Alianza.

López Barinaga, B (2010) Juego. Ed. Alesia.

McLuhan, M (1964) Understanding media: the extensions of man. Ed. McGraw Hill.

Moragas, M. de (Coord.) (1985) Sociología de la comunicación de masas (escuelas y autores). Ed. Gustavo Gili.

Morales Corral, E. (2011) "Los videojuegos: apostar por la cultura multimedia", Capítulo 6 en: Informe sobre la cultura española y su proyección global 2011. Bustamante, E (Coordinador) Páginas 133152. Ed. Fundación Alternativas - Marcial Pons Ediciones Jurídicas y Sociales. [Disponible a fecha 18-03-2015 en: http://www.falternativas.org/la-fundacion/documentos/librose-informes/informe-sobre-la-cultura-espanola-y-su-proyeccionglobal-2011].

Morales Corral, E. (2012) "El smartphone como motor de una nueva incertidumbre social: la importancia de las redes sociales en la comunicación móvil de los jóvenes españoles en la sociedad de la inmediatez". Artículo en Revista Prisma Social No 8. Pp. 87105. [Disponible a fecha 18-03-2015 en: http://goo.gl/7xNH4V].

Neumann, J. V. (1953) Theory of games and economic behavior. Ed. John Willey and Sons.

Thomson, J. B. (1997) Los media y la modernidad: una teoría de los medios de comunicación. Barcelona. Ed. Paidós.

Vargas-Machuca, R (2013) La gamificación al servicio de nuevos modelos de comunicación surgidos de la cibercultura. Ed. Universidad de Sevilla. 


\section{Responsabilidad Social Corporativa y medio ambiente en YouTube}

Carmen Costa

\section{Universidade da Coruña}

\section{Resumen}

La comunicación empresarial externa ha incorporado YouTube a los canales con los que comunicarse con sus públicos. El presente estudio pretende conocer la importancia de la temática de Responsabilidad Social Corporativa y, en concreto, la medioambiental, en los contenidos que nutren dichos canales empresariales. ¿Es visible la preocupación por el medio ambiente de las empresas españolas en dicha red social?, sería la pregunta de partida. La metodología empleada es el análisis de contenido.

Los resultados muestran que, a nivel cuantitativo, los vídeos de RSE han logrado un espacio en YouTube, sin embargo, los contenidos medioambientales presentan en el contexto actual una presencia anecdótica.

Palabras clave: Medio ambiente, YouTube, Responsabilidad Social Corporativa, RSC, Comunicación Empresarial

\section{La Responsabilidad Social Corporativa como filosofía de gestión empresarial y de relaciones con los públicos}

— $\mathrm{N}$ el contexto actual, caracterizado por una doble crisis, económica y político-institucional que afecta a la clase política y 
a los partidos mayoritarios (CIS, Estudio 3041, octubre de 2014), de cansancio generalizado ante prácticas poco éticas y abusivas por parte de empresas, de agentes políticos y de instituciones, las organizaciones buscan recuperar la credibilidad y la confianza de los ciudadanos.

A esto también contribuye el marco contextual de una sociedad sensibilizada hacia los problemas medioambientales o económicosociales, así como la expansión de una economía de servicios altamente competitiva, donde la amalgama de mensajes informativos y publicitarios dificultan la diferenciación de las marcas. Tal y como explica Salmon (2008: 55),

"la marca debe volver a encontrar una identidad fuerte y coherente que hable tanto a los consumidores como a los colaboradores de la empresa [...] y condense en un relato coherente todos los elementos constitutivos de la empresa: su historia, la naturaleza de los productos que fabrica, la calidad del servicio a la clientela, las relaciones laborales, la relación con el medio ambiente...".

La Responsabilidad Social Corporativa representa un cambio de paradigma desde la clásica mentalidad de gestión empresarial basada en el estricto beneficio económico a un sistema relacional más igualitario y transparente entre empresa y públicos. Esta nueva óptica de gestión apela a la contribución desde la actividad empresarial al medio ambiente, al bienestar de sus profesionales y de la sociedad en general.

Según Forética, ${ }^{29}$ es el fenómeno voluntario que busca conciliar el crecimiento y la competitividad, integrando al mismo tiempo el compromiso con el desarrollo social y la mejora del medio ambiente.

Dicha "voluntariedad" empresarial puede "rentabilizarse", no obstante, en términos de reputación corporativa y de comportamiento

\footnotetext{
${ }^{29} \mathrm{http}: / /$ foretica.org/index.php/conocimiento-rse/que-es-rse?lang=es
} 
del consumidor hacia la marca, es decir, puede ayudar a recuperar la confianza.

La RSC abarca toda una serie de actuaciones no vinculantes (es decir, no legalmente exigibles a las empresas), pero cuya fuerza vinculante procede de la íntima convicción por parte de los grupos sociales de que su incumplimiento constituye o puede constituir un grave atentado a la interpretación más adecuada de la norma de cultura y, todas ellas vinculadas de alguna forma a los grupos sociales (stakeholders) implicados en la marcha de la empresa (García \& Llorente, 2008). Dichas acciones se desarrollan en una doble dimensión interna-externa. Según el Libro Verde de la Unión Europea (2001), la primera afecta a los empleados y al medioambiente e incluye la gestión de recursos humanos, la salud y seguridad en el trabajo, y la gestión ambiental y de los recursos naturales; la segunda hace referencia a las relaciones con la comunidad, con los proveedores y consumidores, los derechos humanos y los problemas ecológicos mundiales.

Los principios que la rigen son (Fernández García, 2009: 20):

- El cumplimiento de la legislación nacional vigente, así como de los tratados internacionales.

- Su carácter global ya que afecta a todas las áreas de la empresa, así como a todas las delegaciones o filiales de la misma.

- Comporta compromisos éticos objetivos, que se convierten en obligación para quien los contrae.

- Se manifiesta en los impactos de la actividad empresarial a nivel medioambiental, económico y social.

- Se orienta a la satisfacción de las necesidades de los grupos de interés.

El enfoque actual de dicho rol empresarial parte, por lo tanto, de lograr el entendimiento de la organización con sus stakeholders (clientes, colaboradores, proveedores, ciudadanos, instituciones, otras empresas, grupos ecologistas, etc.), lo que la aproxima enormemente al concepto de Relaciones Públicas. 
"Este ambicioso propósito implica necesariamente escuchar y atender las demandas sociales, satisfacer los intereses generales, resolviendo necesidades particulares. La comunicación y la persuasión dan paso a la negociación. La responsabilidad social deja de ser un instrumento para convertirse en la piedra angular de la gestión de las organizaciones" (García Nieto, 2011: 5).

Debe subrayarse que la RSC no es o no debe ser un instrumento puntual, ni una operación de maquillaje de la realidad empresarial. Hay que hacerlo bien, hacerlo saber y hacerlo saber bien. La RSC integra los tres pasos de esta receta en tres etapas que se recomienda para una buena comunicación corporativa. Forma parte del hacerlo bien si se incorpora como modelo de gestión empresarial. También se integra en la segunda etapa (hacerlo saber), si se siguen sus principios de transparencia informativa. Y, finalmente, del último eslabón -el hacerlo saber bien- si es la óptica que predomina en la gestión informativa realizada.

"En un nivel táctico, la RSC repercute en la imagen de la organización, en un tono más persuasivo, sin embargo, a nivel estratégico, repercuten en la reputación corporativa, la confianza en la organización y en el establecimiento de relaciones beneficiosas en ambos sentidos" (Viñarás Abad, 2010: 99).

Su protagonismo es creciente en campañas publicitarias a través de los medios de comunicación (Costa-Sánchez, 2014 a; Vega Muñoz, 2012). Las marcas quieren dar a conocer su comportamiento voluntariamente cooperativo y responsable. Constituye parte de su apuesta actual por construir una relación de confianza con el consumidor.

\section{YouTube, la nueva televisión online 2.0}

La Comunicación Corporativa necesita adaptarse a medida que el entorno social, tecnológico, organizacional, etc. va cambiando. Las recientes transformaciones en la forma de comunicarnos y de 
informarnos han originado una evolución hacia herramientas participativas y bidireccionales en el contexto de la Web 2.0.

Ello contribuye a transmitir con mensajes pensados para los nuevos medios (los llamados social media), cada vez más audiovisuales.

"The development of the Web 2.0 is indirectly provoking an avalanche of audiovisual content, and its capacity to create communities provides an extensive use of audiovisual formats" (Lloret y Canet, 2008).

YouTube -red social creada en 2005 por Chad Hurley, Steve Chen y Jaweb Karim, en Estados Unidos- permite compartir videos en la Red de forma gratuita e ilimitada, así como generar conversaciones entre los usuarios mediante comentarios. Es el social media audiovisual por excelencia (a gran distancia de Vimeo o de Vine, por ejemplo), en el que ciudadanos y organizaciones pueden crear y difundir sus propios formatos audiovisuales y crear sus propios canales.

Según la $V$ Oleada del Observatorio de Redes Sociales (publicado en abril de 2013) ${ }^{30}$, YouTube es uno de los social media clasificados como "en boga" en España, con un 52\% de usuarios que tienen cuenta y la utilizan, por detrás del liderazgo de Facebook (83\%), pero superando a Twitter $(42 \%)$ y a otras redes sociales. En los resúmenes mensuales sobre audiencias de medios que publica EGM (Estudio General de Medios), los resultados de las últimas oleadas publicadas -en concreto, la de abril de 2013 a marzo de 2014- muestran que YouTube es el sitio web con más visitantes únicos (un total de 20.272.000 para los últimos 30 días) a mucha distancia del segundo en el ranking, el diario deportivo online Marca.com.

Representa uno de los portales nacidos al amparo de la Web 2.0, como sitio UGC (User Generated Contents). Según explican García Cay et al. (2013), el nacimiento y éxito de You'Tube se enmarca en el cruce de tres revoluciones: la de la producción de video, la de la Web 2.0 y la revolución cultural o de hábitos de consumo audiovisual.

\footnotetext{
${ }^{30} \mathrm{http}: / /$ es.slideshare.net/TCAnalysis/5-oleada-observatorio-redes-sociales
} 
Algunos de los motivos que conducen a la empresas a poner en marcha su canal en YouTube son: la gratuidad, la enorme capacidad de almacenamiento y la alta popularidad del site, lo que favorece un feedback constante (Viana Neto, 2009).

Les ofrece, por tanto, la posibilidad de tener un canal de televisión de la organización de manera gratuita, una televisión a la carta donde los videos pueden ser organizados y agrupados temáticamente y con los que pueden fidelizar usuarios y generar interacción.

Puede decirse que YouTube está llamado a ser el aliado clave de cualquier estrategia audiovisual corporativa a nivel online. Una radiografía actual del empleo de YouTube por las empresas españolas con mejor reputación (Costa-Sánchez, 2014b), pone de relevancia que de las empresas con mejor reputación corporativa, la mayoría dispone de canal corporativo en la plataforma, más allá de los canales de marca o de producto, a pesar de que las dinámicas participativas no son todavía la tónica predominante.

\section{Metodología}

El presente trabajo estudia la visibilidad de las acciones de Responsabilidad Social Corporativa vinculadas con el medio ambiente difundidas a través de los canales de YouTube de las empresas españolas con mejor reputación (Merco 2013).

Las preguntas de investigación de las que parte el presente trabajo son las siguientes:

- ¿Forma parte el medio ambiente de las acciones visibilizadas en dichos canales de comunicación externa? (RQ1)

- En relación con otras áreas de actividad comprendidas bajo la RSC, ¿'es el medio ambiente una línea de actividad más visible que otras? (RQ2)

- En caso negativo, ¿cuál es la temática más visibilizada en el marco de la Responsabilidad Social Corporativa? (RQ2.1).

- ¿Existen diferencias destacables en cuanto a la visibilidad de sus acciones de RSC entre empresas de distintas áreas de actividad? (RQ3) 
- En caso afirmativo, clas empresas de qué sector priorizan el medio ambiente en el marco de sus actividades de RSC? (RQ3.1)

- Teniendo en cuenta que se estudia un canal 2.0 y, en ese sentido, participativo, ¿cuáles son los contenidos de RSC a los que los públicos responden mejor (más visualizaciones, más interacción positiva -me gusta-, o comentarios)?

La muestra de empresas a analizar estuvo conformada por las veinte primeras empresas del ranking de empresas con mejor reputación (Merco 2013). Dicho conjunto empresarial lo integraban las siguientes entidades (ver tabla 1 ):

\begin{tabular}{|l|l|r|}
\hline Nombre & Área de actividad empresarial & Puntuación \\
\hline Inditex & Textil & 10.000 \\
\hline Mercadona & Distribución generalista & 9.829 \\
\hline Santander & Bancario & 8.859 \\
\hline Repsol & Petrolera & 8.402 \\
\hline Iberdrola & Energía, gas y agua & 8.270 \\
\hline Telefónica & Telecomunicaciones & 8.170 \\
\hline BBVA & Bancario & 7.539 \\
\hline Mapfre & Aseguradoras & 7.366 \\
\hline Coca-Cola & Alimentación y bebidas & 7.361 \\
\hline Caixabank & Bancario & 7.064 \\
\hline Google & Informática y electrónica de cons. & 7.026 \\
\hline Acciona & Infraestructuras, servicios y const. & 6.978 \\
\hline Ikea & Distribución y equip. para el hogar & 6.972 \\
\hline Danone & Alimentación y bebidas & 6.836 \\
\hline El Corte Inglés & Distribución generalista & 6.803 \\
\hline Apple & Informática y electrónica de cons. & 6.752 \\
\hline Indra & Consultoría & 6.658 \\
\hline Microsoft & Informática y electrónica de cons. & 6.570 \\
\hline Nestlé & Alimentación y bebidas & 6.461 \\
\hline IESE & Formación & 6.444 \\
\hline
\end{tabular}

Tabla 1. Muestra de empresas estudiada.

Elaboración propia

Se tomó una muestra de 30 vídeos de cada canal (los más recientes). En los casos en los que no había una cantidad suficiente, se tomaron como muestra los videos disponibles (ver tabla 2). 


\begin{tabular}{|l|l|l|l|}
\hline Empresa & $\begin{array}{l}\text { Vídeos } \\
\text { analizados }\end{array}$ & Empresa & $\begin{array}{l}\text { Vídeos } \\
\text { analizados }\end{array}$ \\
\hline Mercadona & 15 & Santander & 30 \\
\hline Iberdrola & 30 & Telefónica & 30 \\
\hline Mapfre & 19 & Coca-Cola & 30 \\
\hline Caixabank & 30 & BBVA & 30 \\
\hline Google & 30 & Acciona & 30 \\
\hline Ikea & 30 & Danone & 30 \\
\hline El Corte Inglés & 30 & Indra & 30 \\
\hline IESE & 30 & TOTAL & 424 \\
\hline
\end{tabular}

Tabla 2. Muestra de vídeos estudiada.

Elaboración propia

Debe tenerse en cuenta, además, que se eligieron los canales corporativos de las empresas indicadas, no los canales de producto ni de marca, al considerar que las acciones de Responsabilidad Social Corporativa deben formar parte de los contenidos de los canales institucionales. Ello implicó la ausencia de determinadas empresas en el análisis. Por ejemplo, Inditex, en su estrategia de marcas desagregadas, lanza un canal por cada marca del grupo (Bershka, Stradivarius, etc.), careciendo en el momento de análisis de un canal corporativo empresarial. Repsol utiliza una estrategia múltiple donde, en lugar de apostar por un canal corporativo, genera distintos canales para sus distintas actividades, como por ejemplo, Guía Repsol o Box Repsol, especializado en el equipo Repsol de motociclismo y sus pilotos. Apple, Microsoft y Nestlé no pudieron ser incluidos por no disponer de los canales de las filiales españolas, requisito, como se recoge en el título, del presente estudio.

\section{Resultados}

Del análisis efectuado, se detecta que 84 de los 424 vídeos analizados tienen como protagonista alguna de las actividades que desarrolla la empresa en cuestión en los ámbitos de Responsabilidad Social Corporativa. Ello supone que prácticamente un $20 \%$ de los contenidos de los canales de YouTube analizados se dedica a abordar alguna actividad de RSE. Los restantes contenidos son informativos o publicitarios de producto o de la organización, pero sin tener como rasgo temático preponderante la actuación de la empresa en materia de Responsabilidad Social Corporativa. 


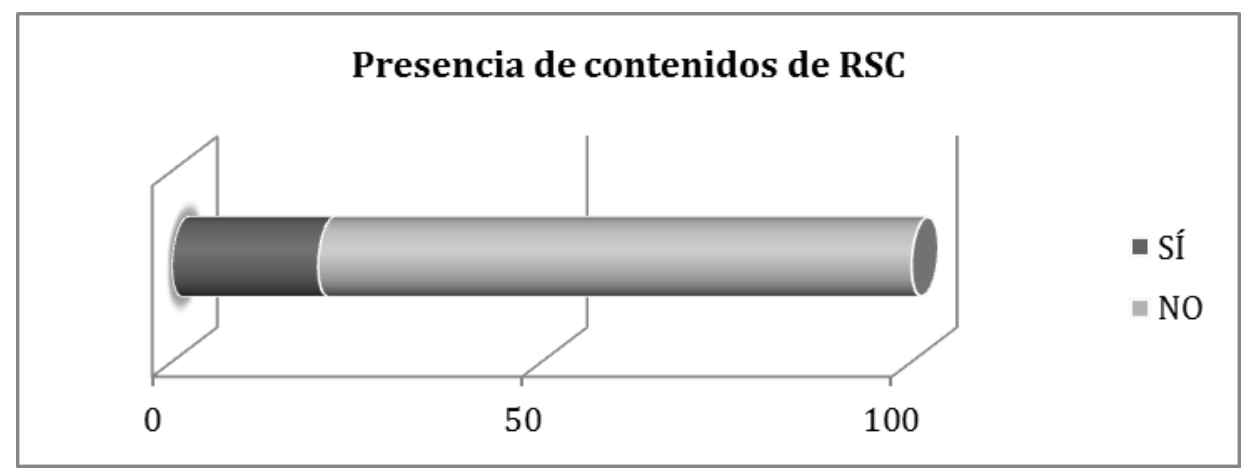

Fuente: Elaboración propia

Por áreas de actividad empresarial, son las empresas del sector bancario, Caixabank y BBVA, las que presentan un mayor número de vídeos destinados a relatar acciones de Responsabilidad Social Corporativa. Teniendo en cuenta el porcentaje muestral, le sigue la energética Iberdrola y la empresa de construcción y servicios Acciona. Las empresas del sector de alimentación y bebidas se ubicarían en una tercera posición (Coca-Cola, Danone o Mercadona).

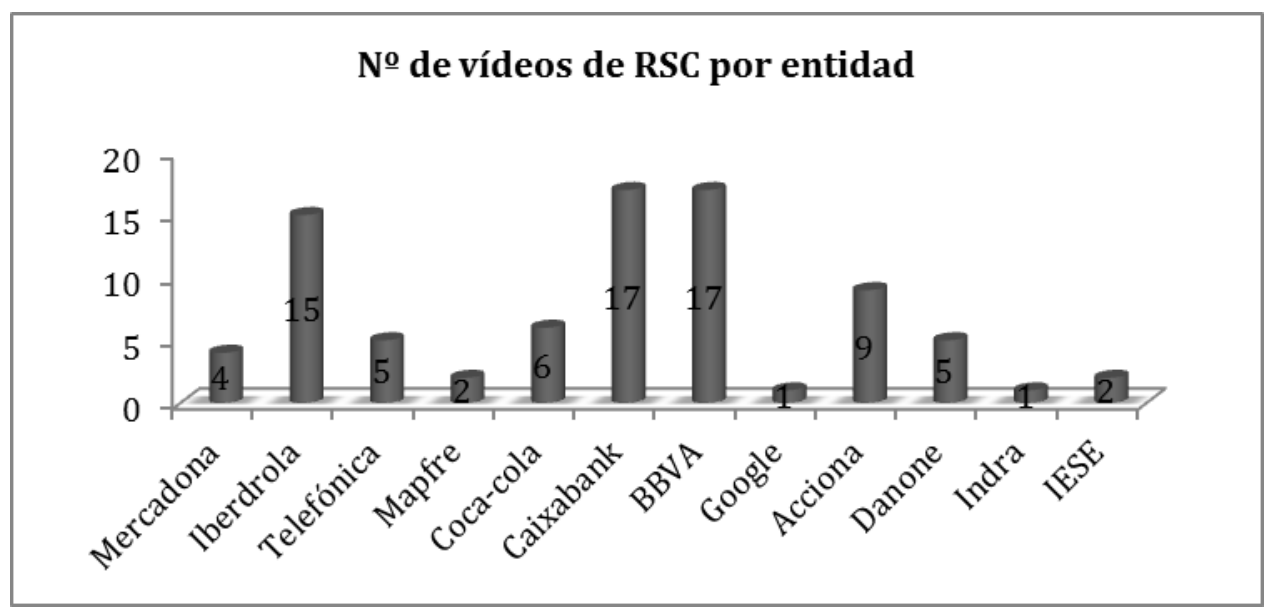

Fuente: Elaboración propia

Por cuanto al formato audiovisual elegido para mostrar las acciones de RSC, se detecta cómo constituyen de por sí un nuevo tipo de contenido audiovisual, no encasillable bajo ninguna de las categorías clásicas como pueden ser el reportaje o el spot publicitario. Le siguen en importancia las videonoticias que tienen como protagonista alguna acción o actividad de RSE, los spots, los microvídeos informativos (considerados así los que no superaban el minuto de duración), las declaraciones de algún portavoz empresarial para explicar alguna de las acciones puestas en marcha y en última instancia videos 
corporativos basados en la importancia de la RSC. En líneas generales, subyace el tono informativo en la mayoría de las piezas audiovisuales generadas sobre RSC, mientras que la finalidad publicitaria con contenidos de este tipo no se aplica de forma mayoritaria. Esto se debe a que el estilo informativo subraya la voluntad de las empresas de dedicar esfuerzos a cuestiones que les preocupan desde un punto de vista transparente e informativo, mientras que aleja la visión de la RSC como una herramienta de marketing y de "venta" en sentido estricto.

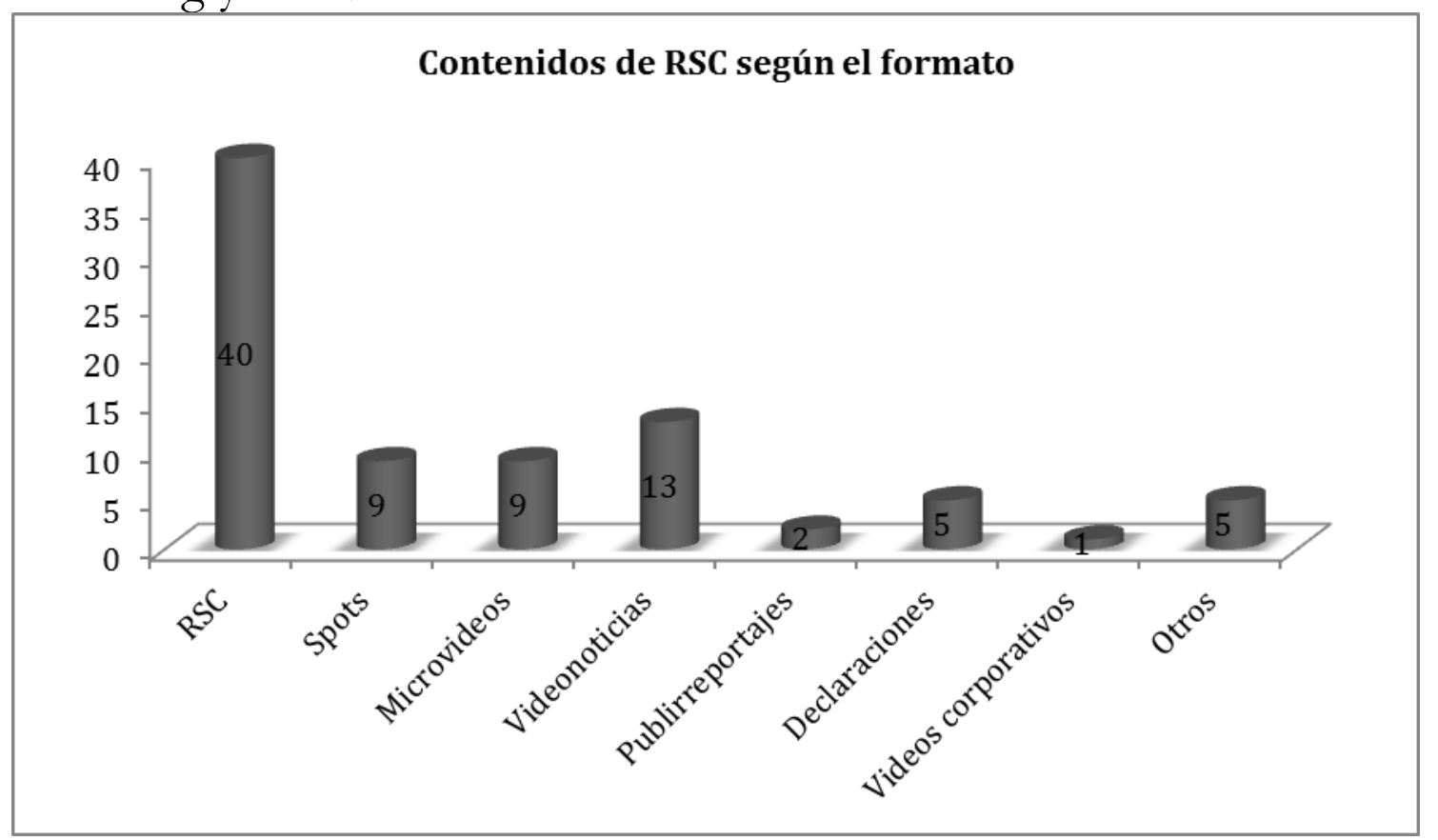

Fuente: Elaboración propia

La Responsabilidad Social Corporativa puede aplicarse en una doble dimensión, interna (hacia el interior de la organización) o externa (hacia la sociedad y su entorno). Para conocer la visibilización de la temática medioambiental en este marco, dichas líneas de actividad han sido categorizadas como: Medioambiente, Económica, Social o la combinación de varias de ellas (si no podía determinarse una preponderante).

Los resultados indican que, por cuanto a la dimensión, se publicitan sobre todo acciones de RSC llevadas a cabo para la mejora de las relaciones externas con los stakeholders. Mientras que los videos que recogen acciones propias de una dimensión interna son minoritarios. Se trabaja poco, por tanto, la finalidad de captación de talento por medio de YouTube, es decir, se proyectan pocos mensajes pensando 
en atraer talento (nuevos profesionales) hacia la empresa. Algún ejemplo de videos que tratan actividades de RSC hacia una dimensión interna serían el Programa Mi invitado (de Iberdrola), una actividad, dirigida a familias de España, Reino Unido y Estados Unidos, que ha facilitado la estancia de hijos de empleados durante cuatro semanas en la casa de compañeros de otros países.

En cuanto a las posibles temáticas abordables desde una dimensión interna-externa, es la línea de actuaciones sociales la predominante, seguida por la línea de actuaciones económicas.

A mucha más distancia, se encuentra la línea de actuaciones medioambientales, lo que permite afirmar que las acciones de RSC en materia medioambiental se encuentran invisibilizadas en el conjunto analizado y en el contexto actual.

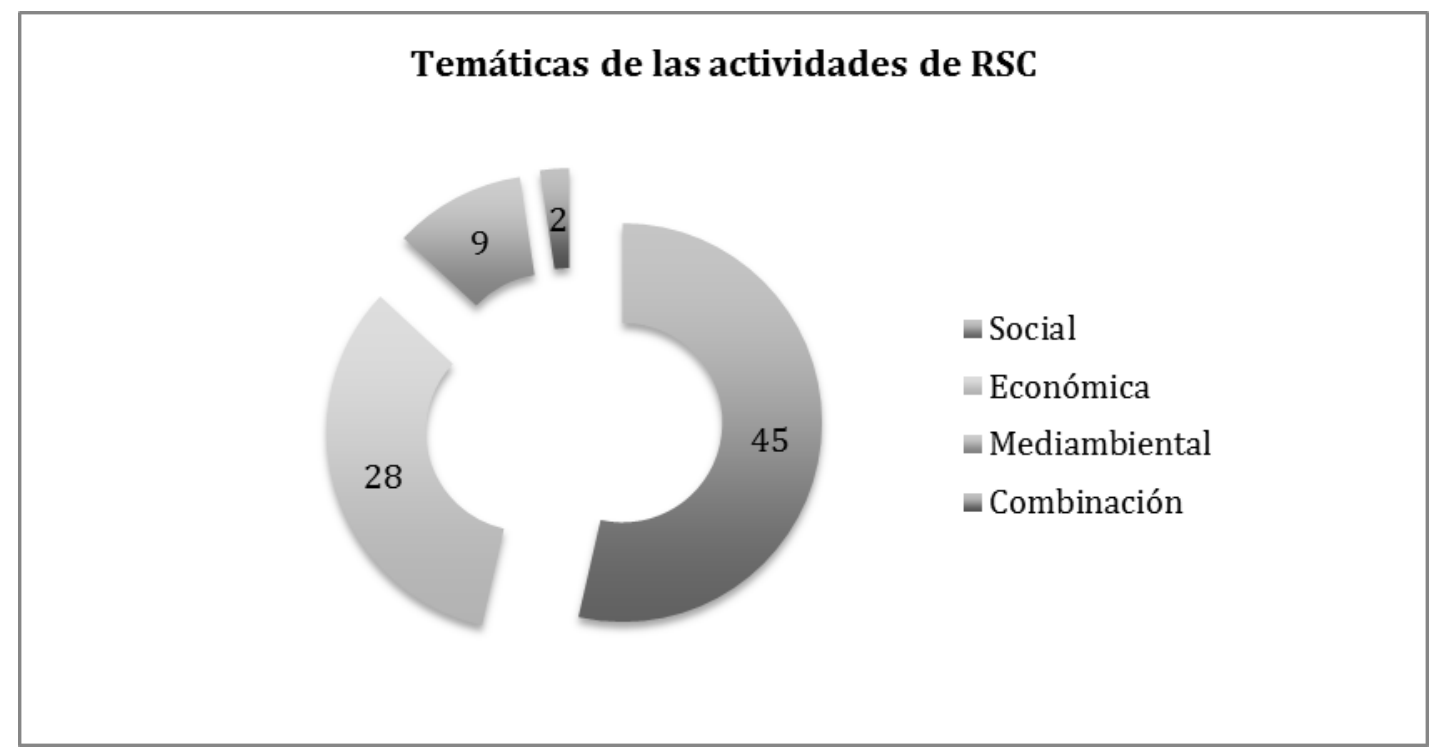

Fuente: Elaboración propia

Por sectores, Acciona es la empresa que más ha tratado la temática de RSC medioambiental en los vídeos de su canal de YouTube. Algunas de las piezas que han relatado estas experiencias son:

- Aprovechando el Día Mundial del Agua, la empresa recoge el desarrollo de un método que permite el uso de sustancias generadas en los procesos de depuración y desalinización de aguas para la propia alimentación energética de las plantas.

- Su apuesta por las principales tecnologías renovables. 
- El proyecto de "Co-digestión de lodos" que ACCIONA ha puesto en marcha en una depuradora, galardonado por el diario Cinco Días en la categoría Proyecto Empresarial más Innovador en el Campo de las Nuevas Tecnologías.

- Información útil y educativa para el consumidor acerca del reciclaje de plástico y de vidrio (los secretos del ciclo de vida del plástico y el vidrio).

Otras piezas audiovisuales de otras entidades que han tratado aspectos o actividades de cuidado y respeto hacia el medio ambiente de forma destacable han explicado en qué consiste una cadena agroalimentaria sostenible (Mercadona); han abordado iniciativas de $\mathrm{I}+\mathrm{D}$ mediante las que se persigue diseñar un dispositivo para reducir las emisiones de las centrales convencionales de generación de energía eléctrica y las plantas industriales (Iberdrola); han tratado la importancia y el ahorro que supone el uso de vehículos ecológicos, híbridos y eléctricos (Mapfre).

Cabe destacar, en el caso de Mercadona, un interés constante por visibilizar videos donde se muestre la colaboración de la empresa con cooperativas y empresas del sector primario que garantizan un producto natural y de calidad, que luego ofrecen a los consumidores. De esta forma, se busca un triple impacto positivo: Primeramente, su colaboración con entidades del sector primario (pesquero y agrícolaganadero); en segundo lugar, su interés por una cadena de producción sostenible y responsable; y, en tercer lugar, su apuesta por un producto natural y de calidad para los consumidores. Como explica Costoya Otero (2013), Mercadona busca abastecerse con integridad; quiere ofrecer a sus clientes productos de calidad a un precio justo, actuando correctamente con los agricultores, productores y trabajadores involucrados.

En cuanto a la participación generada por los videos, a nivel de comentarios en el conjunto analizado, la participación es muy baja, nueve comentarios es el máximo que se alcanza para un vídeo sobre el programa de BBVA, Yo soy empleo. Con respecto a la interacción positiva (me gusta), el video con más interacciones positivas es el del coro "Las Voces de la Memoria", de Coca-Cola España con la 
colaboración de la coral infantil "Noves Veus de Fátima", para la felicitación del año 2014. Las Voces de la Memoria es una coral compuesta por enfermos de alzheimer que pertenecen a la Asociación Alzheimer de Valencia.

El siguiente vídeo de RSC que más gusta corresponde al canal de Mercadona y es un video explicativo y de agradecimiento a los hogares que confían en la empresa, al esfuerzo de todos sus trabajadores y a las empresas con las que colabora. También "gracias a la acogida que tiene su modelo de empresa en la sociedad".

En cuanto al número de reproducciones, los tres vídeos con mayor número de visualizaciones son los tres spots de BBVA sobre su programa Yo soy empleo, que pretende apoyar económicamente a PYMES y autónomos que decidan contratar a personas desempleadas.

\section{Conclusiones. De lo medioambiental a lo económico-social}

El medioambiente se ha convertido en una temática derogada en contexto de crisis económica en contraposición a lo que acontecía previamente a la crisis (Moreno y Capriotti, 2006: 57). La muestra de empresas analizadas, todas ellas grandes empresas, apuestan por temáticas de tipo social o económico como protagonistas de las acciones de RSC que visibilizan a través de sus canales de YouTube, con especial importancia del "elemento empleo". Lo que se intenta priorizar, en el marco actual, es el esfuerzo y la solidaridad empresarial ante un contexto de grandes dificultades para las familias y los ciudadanos en España.

Esto mismo se adelantaba con respecto a las áreas de actividad en la evaluación más reciente realizada en el Informe Forética 2011, en el que se explicaba que las prioridades de RSE se adaptan al ciclo económico y los aspectos ambientales pierden importancia de manera progresiva, mientras que las variables de acción social y las asociadas a la gestión no han sufrido variaciones significativas (Forética, 2011).

Parece haber coincidencia, pues, entre lo efectuado y lo comunicado. De esta forma, la principal conclusión de este estudio recoge que se 
está llevando a cabo una adaptación al menos de la visibilidad de la actividad de RSC al contexto español de crisis económica y elevadas cifras de desempleo con acciones económico-sociales como las más destacadas. De hecho, una acción repetida en distintos canales empresariales por empresas de perfiles muy distintos es la recogida o donación de alimentos (banco de alimentos) para ayudar a familias con necesidades en España. En consecuencia, se han dejado en un segundo lugar las acciones vinculadas con el respeto, la preocupación y el compromiso con el medioambiente. De aquí aún puede extraerse una conclusión ulterior. La comunicación de RSC por medio de YouTube tiene una patente intencionalidad en términos de reputación corporativa, pues dicho esfuerzo de adaptación pretende conectar con la sensibilidad ciudadana en el contexto actual.

Dentro de la pequeña presencia de temática ambiental, destacan las empresas del sector de las energías y de la construcción y servicios, es decir, Iberdrola y Acciona. Concordamos con los resultados de otros estudios (Lalueza, 2010), que apuntaban que las empresas potencian su labor divulgadora en aquellas actividades que, por el sector empresarial en el que trabajan, implican un área especialmente sensible o conflictiva para sus relaciones con los públicos. De ahí que la RSC pueda entenderse como una filosofía de gestión y de relaciones con los stakeholders.

Se concluye que las entidades bancarias apuestan decididamente por visibilizar sus acciones en materia económico-social, en un contexto en que se ha cuestionado su transparencia y honestidad para con los consumidores (preferentes, diversos escándalos vinculados a las cajas de ahorros, polémica por los altos salarios o jubilaciones de sus ejecutivos, tarjetas black, desahucios, etc.). De esta forma, el sector bancario pretende construir una imagen más solidaria respecto a los problemas sociales actuales. En la línea de lo concluido por PérezRuiz y Rodríguez-del Bosque (2012), desde el punto de vista de los clientes, los bancos aún tienen que seguir trabajando en desprenderse de la imagen de ser entidades fuertemente orientadas al beneficio, puesto que la responsabilidad hacia los accionistas no resulta especialmente relevante para los usuarios de servicios financieros españoles. 
Son estos, por otra parte, los vídeos que, a priori, más interés han despertado en los usuarios que, quizás porque se proponían iniciativas que podían resultarles de interés (el programa Yo soy empleo, de BBVA o el proyecto Gira de Coca-Cola España), se han mostrado incentivados a verlos, más que respecto a otro tipo de contenidos. Por otra parte, resulta lógico al tratarse de la temática mayoritaria.

Resulta destacable el caso de Mercadona por aunar medio ambiente y gestión empresarial, de manera que visibiliza una forma de aplicar la RSC no puntual en acciones concretas, sino estratégica, es decir, como modelo de relación con sus proveedores y, en último término, con los consumidores.

Se observa además el protagonismo creciente del compromiso laboral con colectivos que presentan capacidades diferenciales. Su inserción laboral o su atención y participación en programas de voluntariado han sido temas visibilizados en el conjunto de los resultados expuestos.

Se propone como línea de investigación de futuro la realización de una comparativa entre los resultados actuales y un nuevo análisis, una vez que la crisis económica haya mitigado su presencia y efectos. Ello permitiría demostrar si el medio ambiente recupera importancia y protagonismo en el marco de la Responsabilidad Social Corporativa de las empresas españolas con mejor reputación una vez que el contexto económico-social haya mejorado.

\section{Referencias}

Costa Sánchez, C. (2014). "Storytelling y audiovisualización de la comunicación corporativa: las claves de la campaña "Gracias por elegirnos" (Balay) en Revista Organicom - Revista brasileira de Comunicaçao Organizacional e Relaçoes Públicas, 11 (20), pp. 163-176. Disponible en: http://revistaorganicom.org.br/sistema/index.php/organicom /article/view/698 
Costa-Sánchez, C. (2014b). “Audiovisual y Web 2.0. Empleo de YouTube por las empresas españolas con mejor reputación”, en Chasqui. Revista Latinoamericana de Comunicación, 126, pp. 21-41. Disponible en:

http://dspace.ciespal.net/index.php/chasqui/article/view/252

Costoya Otero, I. (2013). Análisis de la estrategia de Responsabilidad Social Corporativa de Mercadona: formulación de propuestas de mejora, A Coruña: Universidade da Coruña.

Fernández García, R. (2009). Responsabilidad Social Corporativa, Alicante: Editorial Club Universitario.

Forética (2011). Informe Forética 2011. Disponible en http://foretica.org/sala-de-prensa/noticias/1190-presentadoel-informe-foretica-2011?lang=es

García Cay, A. et al. (2013). "YouTube: la clave de los canales con mayor número de suscriptores en España", en Pérez Rufí, J. P. (coord.), Industrias audiovisuales: Producción y consumo en el siglo XXI, Málaga: Universidad de Málaga, pp. 6-28.

García Nieto, M. T. (2011). "La regulación de la Responsabilidad Social Corporativa en España" en Derecom, no 6, pp. 1-16.

Lalueza i Bosch, F. (2010). "Exprimiendo la RSC. Las empresas socialmente responsables y sus proclamas ante los medios de comunicación." Comunicación presentada al II Congreso de la Asociación Española de Investigación en Comunicación.

Lloret Romero, N. y Canet Centellas, F. (2008). "New stages, new narrative forms: The Web 2.0 and audiovisual language", en Hipertext.net, $\mathrm{n}^{\circ} 6$, disponible en http://www.upf.edu/hipertextnet/en/numero-6/lenguajeaudiovisual.html

Moreno, Á., \& Capriotti, P. (2006). "La comunicación de las empresas españolas en sus webs corporativas. Análisis de la información de responsabilidad social, ciudadanía corporativa y desarrollo sostenible", en Zer-Revista de Estudios de Comunicación, 11(21), pp. 47-62.

Pérez Ruiz, A., \& Rodríguez del Bosque Rodríguez, I. A. (2012). "La imagen de Responsabilidad Social Corporativa en un contexto de crisis económica: El caso del sector financiero en España", en Universia Business Review, primer trimestre 2012, pp. 14-29. 
Salmon, C. (2008). Storytelling: la máquina de fabricar historias y formatear las mentes. Barcelona: Ediciones Península.

Vega Muñoz, P. (2012). La responsabilidad social corporativa (RSC) como instrumento estratégico de comunicación para el incremento del valor de marca: el caso de la publicidad televisiva, tesis de magíster, Ecuador: Universidad Andina Simón Bolívar. Disponible en: http://repositorio.uasb.edu.ec/handle/10644/2955

Viana Neto, J. A. (2009). YouTube como veículo de divulgação da comunicação corporativa. Centro Universitario de Brasilia. Disponible en: http://repositorio.uniceub.br/handle/123456789/2131

Viñarás Abad, M. (2010). "El discurso de la RSC en los medios de comunicación social”, en Vivat Academia, No. 110, 2010, pp. 90104. 


\title{
Herramientas de comunicación que mejoran la experiencia del turista
}

\author{
Verónica Altamirano \\ Universidad Técnica Particular de Loja \\ Miguel Túñez \\ Universidad Santiago de Compostela
}

\section{Resumen}

La comunicación turística adquiere relevancia en el entorno mundial gracias a la creciente importancia del turismo como generador de desarrollo y alternativa de crecimiento económico en diversos países, por lo tanto debe adaptarse a la constante evolución de las nuevas tecnologías de la información y de la comunicación.

La promoción y difusión turística internacional incrementa en sus estrategias de comunicación herramientas y recursos multimedia, así como aplicaciones para dispositivos móviles, de geolocalización y recursos para descargar que aportan al turista facilidades para el viaje y permiten mejorar la experiencia durante la visita, cumpliendo con las exigencias del turista 2.0.

Palabras clave: Comunicación turística digital, herramientas digitales, aplicaciones móviles. 


\section{Introducción}

T A actividad turística es considerada en la actualidad uno de los principales factores de desarrollo económico y social a nivel mundial, debido a los ingresos económicos que se generan para las arcas gubernamentales, ya sea a través del turismo interno o externo. A su vez, el desarrollo sostenible de turismo influye en el surgimiento y crecimiento de pequeños y medianos negocios, aportando también a la generación de fuentes de empleo, que se vinculan de manera directa o indirecta a la actividad.

Según la Organización Mundial de Turismo (OMT) ${ }^{31}$, en el 2014 la llegada de turistas internacionales alcanzó un récord de 1.133 millones en todo el mundo frente a los 1.087 millones en el 2013. Con 46 millones más de turistas viajando (+ 4,3\%), el 2014 marca el quinto año consecutivo de crecimiento por encima de la media a largo plazo ( $+3,3 \%$ anual) desde la crisis financiera del 2009. En este periodo gracias a la actividad se recaudó un estimado de 1.245 billones de dólares (937 millones de euros), equivalente a un incremento de 3.7\% (0MT; 2015; 4-5).

En el Barómetro OMT del turismo mundial $(2015 ; 4-5)$ también se detalla la evolución por región. Europa $(+3 \%)$ lideró el crecimiento en términos absolutos, se incrementó el arribo de 15 millones de turistas internacionales en el 2014 para llegar a un total de 582

\footnotetext{
${ }^{31}$ OMT. La Organización Mundial del Turismo (OMT) es el organismo de las Naciones Unidas encargado de la promoción de un turismo responsable, sostenible y accesible para todos, como principal organización internacional en el ámbito turístico, aboga por un turismo que contribuya al crecimiento económico, a un desarrollo incluyente y a la sostenibilidad ambiental, y ofrece liderazgo y apoyo al sector para expandir por el mundo sus conocimientos y políticas turísticas.
}

La OMT también genera conocimiento de los mercados, promueve políticas e instrumentos de turismo competitivo y sostenible y fomenta la enseñanza y la formación en materia de turismo, constituyéndose en un referente por los estudios que presenta en este campo. 
millones de visitantes, lo que permitió la recaudación de 509 billones de dólares (383 billones de euros).

Las Américas registraron un crecimiento del 8\% en las llegadas internacionales para alcanzar los 181 millones de visitantes, es decir 13 millones de turistas más que en el 2013, generando un incremento de 10 billones de dólares correspondiente a un total de 274 billones de dólares (206 billones de euros). Asia y el Pacífico experimentaron un aumento del 5\%, equivalente a 14 millones más de turistas, con el total regional de 263 millones de llegadas que supusieron un incremento del 16 billones de dólares, alcanzando los 377 billones de dólares (284 billones de euros).

El turismo internacional en Medio Oriente $(+5 \%)$ se recuperó después dos años de descenso, registrando buenos resultados en la mayoría de los destinos. La región atrajo 3 millones de turistas internacionales más que en el 2013, recibiendo un estimado de 51 millones de visitantes que aportaron con 49 mil millones de euros (37 millones de euros) al presupuesto nacional.

En África, el número de turistas internacionales creció en un estimado del $2 \%$, equivalente a un aumento de un millón de llegadas, para alcanzar un total de 56 millones de turistas que gastaron 36 billones de dólares (27 billones de euros).

En el 2015 se espera que el crecimiento continúe a un ritmo sostenido de $3 \%$ a $4 \%$ en todo el mundo.

Este importante crecimiento en la actividad se genera gracias a la globalización e internacionalización del mercado turístico, que se ve influenciado por aspectos como el "surgimiento de nuevos destinos, la segmentación del mercado, la tendencia hacia el viaje independiente, la oportunidad que brindan las TICs para promocionar los servicios turísticos de manera directa, la aparición de webs especializadas en viajes que ofrecen alternativas económicas alrededor del mundo, la asistencia voluntaria que ofrecen otros viajeros generando información en blogs especializados o valorando los servicios y destinos, entre otros" (Altamirano \& Túñez; 2014; 68). 
Todos ellos son aspectos que recalcan la importancia de desarrollar una comunicación turística digital para atraer al público internacional.

Gráfico 1. Desarrollo turístico en el mundo

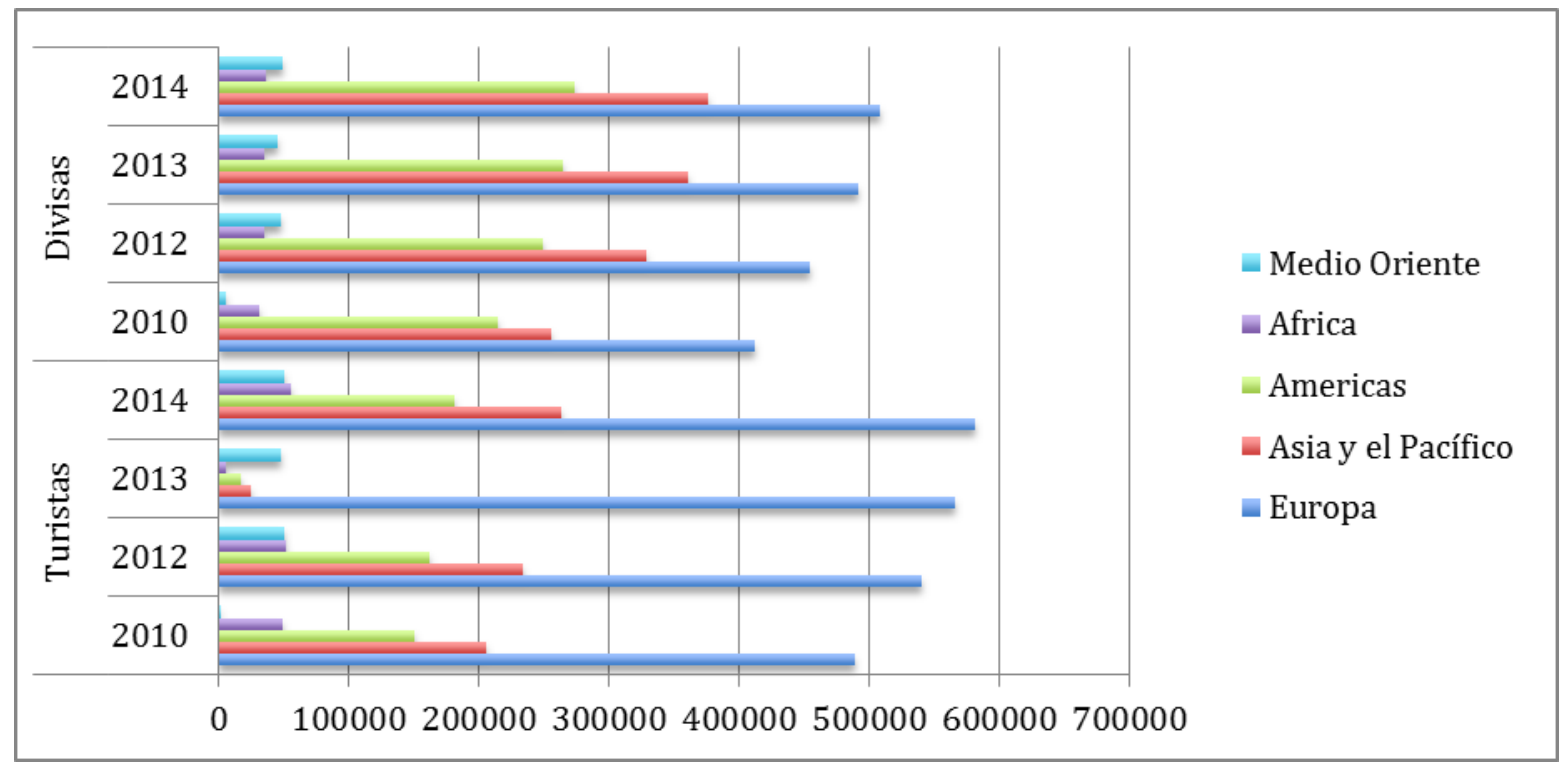

Fuente: Altamirano \& Túñez, en base a datos de la OMT 2015

La Organización Mundial de Turismo desarrolla el Tourism Towards 2030, un proyecto de previsión a largo plazo, iniciado en la década de 1990 que se centra en el estudio de las proyecciones de los flujos de turismo internacional en las dos décadas 2010 - 2030. En esta investigación se, analizan los datos reflejados en las llegadas de turistas internacionales según los informes de los países de destino, teniendo en cuenta la subregión de destino, la región de origen, modo de transporte y el propósito de la visita durante el período 1980 2010 .

Basada en estos análisis, la OMT (UNWTO General Assembly 19 th Session, 2011) sostiene que el crecimiento global de las llegadas de turistas internacionales continuará, pero, a un ritmo moderado $(3 \%)$. Como resultado de los siguientes factores: menor crecimiento del PIB, ya que las economías se estabilizaron; menor elasticidad de los viajes y la tendencia al aumento de los costos de transporte. Las proyecciones turísticas hasta el 2030, confirman que todavía hay un gran potencial para una mayor expansión en las próximas décadas. 


\section{Turista 2.0}

La influencia de las Nuevas Tecnologías de la Comunicación y de la Información en el ámbito turístico es evidente. Su uso y aplicación ha incidido no solo en la forma como se promocionan y difunden los destinos turísticos, sino también en los hábitos de consumo de los turistas y, en consecuencia, en los procesos de planificación y compra.

Al referirnos a la actividad turística hablamos de experiencias, por lo tanto, el uso de las TICs deja de ser informativo y se extiende al campo vivencial a través de los recursos digitales -vídeos, realidad virtual, juegos, fotografías $360^{\circ}$, visitas virtuales, etc.- aplicaciones móviles y de geolocalización que asesoran al viajero y le permiten tener un primer acercamiento al destino o al producto turístico, generando una experiencia previa que motiva e influye en el proceso de selección.

En este escenario se desenvuelve, y se podría decir que lo controla el turista 2.0, un viajero que organiza su viaje de una manera independiente, que se asesora en internet ya sea a través de las webs turísticas o en entornos colaborativos en los cuales otros viajeros comparten sus experiencias, valoran y referencias los productos turísticos, modificando de esta manera los procesos tradicionales para la organización del viaje. En resumen, el turista 2.0 es "un viajero más informado que nunca, participativo, que busca y compara y que ya no decide a partir del consejo de una agencia de viajes, sino que ha de ser persuadido directamente por el producto o servicio turístico y la forma en que éste se presenta en Internet" (Suau; 2012: 144); se convierte en un verdadero ADPROSUMER (AD - anuncio, PRO productor y SUMER - consumidor). Es decir, hace las funciones simultáneas de comprador, consumidor y recomendador de productos. Antes, porque busca opiniones y compra; durante, porque comunica sus impresiones a través de las redes sociales, blogs y sistemas de mensajería $y$, después, porque genera opiniones y reputación en el destino (Caro, Luque \& Zayas; 2014). Se puede asegurar, por tanto, el turista 2.0 es un promotor turístico voluntario y comprometido que se desenvuelve en comunidades colaborativas. 
Los cambios de los hábitos de selección y compra del turista inciden en la forma como se debe realizar la promoción y la difusión de un destino o de un producto turístico. "En el caso del turismo, el proceso se inicia con el surgimiento de la necesidad de viajar, por los motivos que sean. El consumidor buscará, a continuación, información sobre las ofertas existentes en el mercado que puedan satisfacer de forma adecuada su necesidad. La fase posterior consistirá en la evaluación de las distintas alternativas que se le ofrecen. Después del proceso de evaluación de las alternativas, el consumidor seleccionará la que considere satisface de forma más conveniente su necesidad... Por último una vez utilizado el servicio, se entra en la última fase, y no por ello menos importante, sino todo lo contrario, de evaluación del grado de satisfacción con la compra efectuada... Todo el proceso de decisión de compra está influido y condicionado, tanto por variables internas del individuo como por variables externas, además de los estímulos de marketing a los que puede verse expuesto el consumidor." (Serra; 2011: 122).

Ortega \& Rodríguez (2012: 6), citando a Fessenmaier y Jeng, 2000; Choi, Lehto y Oleary, 2007, afirman que el proceso de decisión de compra de los turistas no finaliza con la elección del destino y con la contratación, habitualmente, del alojamiento y del transporte hasta el destino. El proceso continúa a partir de la llegada de los turistas al destino, en donde éstos tendrán ocasión de disfrutar de su estancia en él. Y al mismo tiempo, tendrán que tomar diferentes decisiones sobre la contratación de servicios de restaurantes, visitas recreativas, asistencia a espectáculos, etc. de las que se derivan diversas experiencias. Estas decisiones que tienen lugar en los destinos elegidos, han sido calificadas en la literatura académica como decisiones secundarias, frente a las decisiones principales $o$ fundamentales que tienen lugar en los mercados emisores en donde habitualmente residen turistas.

Según el estudio "Usos, actitudes y tendencias del consumidor digital en la compra y consumo de viajes", realizado por Observatorio Digital IAB Spain (2012), los internautas no desconectan cuando realizan un viaje por motivos de ocio o turismo. Al contrario, Internet continúa desempeñando un papel central cuando se encuentran en 
sus destinos. Sus usos son muy diversos y están estrechamente vinculados al consumo:

- Ocho de cada diez (81\%) utilizan Internet para informarse sobre qué lugares visitar. Alrededor de dos tercios recurre a la red para tomar decisiones relacionadas con la oferta de ocio y cultural $(69 \%)$ o de alojamiento (63\%).

- Entre los usos más novedosos, destaca el acceso a las aplicaciones móviles de geolocalización. Ya las utiliza uno de cada cuatro internautas (29\%). La mitad (49\%) ha accedido a Internet para compartir o comentar buenas experiencias con el servicio recibido en hoteles, restaurantes o medios de transporte. Un 35\%, lo hizo para socializar sus malas experiencias.

Esta variación en el comportamiento del turista ha influido para que la empresa del turismo evolucione hacia lo digital y en este espacio confluyan la oferta y la demanda.

\section{Convergencia digital de la comunicación turística}

Vivimos en una sociedad participativa y colaborativa, en la cual los usuarios tienen una necesidad de buscar constantemente información, pero también de generarla y compartirla. De esta forma, los viajeros crean diversas comunidades virtuales que se convierten en referente a la hora de seleccionar un producto turístico. Estas comunidades se crean de manera voluntaria y en la mayoría de los casos de forma independiente a las empresas turísticas. Pero acaban por influir en la manera como las empresas y organizaciones turísticas se comunican con sus públicos, incorporando Internet y las Redes Sociales en sus planes y estrategias de comunicación.

Sin embargo, la clave del éxito de la comunicación digital no es tener presencia en este entorno digital, ni generar información para el turista, sino, "en la búsqueda de modos de gestionarla y hacerla atractiva para los usuarios" (Domínguez \& Araujo; 2012: 226), con la finalidad de acercarse al mercado para generar la necesidad de visitar un lugar, de influir en la selección de determinado producto turístico 
y de atraer al turista.

La convergencia hacia lo digital en la comunicación turística permite que el viajero acceda de manera directa a la oferta e incluso realizar compras online. Pero, frente a la excesiva información que se encuentra en Internet, se requiere que las empresas turísticas, tanto públicas como privadas, generen un valor agregado la promoción y difusión turística en la web, para lo cual se debe incluir contenidos y herramientas de calidad en sus plataformas de promoción digital. Como lo menciona Alfonso Palazón Meseguer (2001), "la mejor propuesta de cualquier sitio web para fidelizar a un usuario es que ofrezca unos contenidos de calidad... disponer de un contenido diferenciador distingue a los sitios web. Esto produce una necesidad que hace que el usuario vuelva a la web de forma habitual. Y de forma clara, el contenido diferenciador ofrece toda una serie de mecanismos (foros, tablón de anuncios, chat, correo electrónico...) para establecer una relación con el usuario".

Por esta razón, en la actualidad, es necesario que la promoción que se realiza a partir de los sitios web se complemente con la creación de cuentas en las principales redes sociales generalistas para fomentar una comunicación interactiva en la que se consiga la participación voluntaria del usuario como generador de contenidos y promotor de los destinos turísticos. No es importante tener presencia, porque lo que se requiere es el compromiso y la participación activa para fomentar comunidades interactivas.

Las plataformas digitales son creadas con la finalidad de promocionar la oferta turística, pero se debe recalcar que el turista 2.0 exige experiencias y contenidos de calidad. Por lo tanto, las empresas turísticas deben ofrecer un valor añadido en sus sitios web y en las redes sociales, complementando su oferta con información de interés para el turista. De esta forma, se deben incluir contenidos que complementen las necesidades de información del viajero.

La satisfacción del turista se produce en función de las experiencias que vive durante el viaje, que abarca desde que abandona su lugar habitual hasta el retorno. Actualmente, con las Tecnologías de la 
Información y la Comunicación, esta experiencia se extiende al proceso de selección, compra y planificación. Por lo tanto, los recursos adicionales que un portal o red social turística ofrezca al viajero para mejorar su experiencia serán valorados, pueden influir en la decisión de compra e incrementarán el nivel de satisfacción del turista.

Tabla 1: Contenidos turísticos.

\begin{tabular}{|c|c|}
\hline Oferta turística & $\begin{array}{l}\text { Se debe presentar de forma segmentada de manera que } \\
\text { faciliten la navegación del usuario }\end{array}$ \\
\hline $\begin{array}{l}\text { Información del } \\
\text { país y ciudad }\end{array}$ & $\begin{array}{ll} & \text { Historia } \\
\circ & \text { Organización política } \\
\circ & \text { Cultura y tradición } \\
\circ & \text { Marca País }\end{array}$ \\
\hline $\begin{array}{l}\text { Información } \\
\text { para la } \\
\text { planificación de } \\
\text { viaje }\end{array}$ & $\begin{array}{ll}\text { Requisitos de ingreso al país / Trámites de visado } \\
\circ \text { Normativa de la Aduana } \\
\circ \text { Moneda / Convertidor de moneda / Valor del } \\
\text { cambio } \\
\text { - Información Meteorológica } \\
\circ \text { ¿Qué hacer? } \\
\circ \text { ¿Cómo llegar? } \\
-\quad \text { Calendario turístico } \\
\end{array}$ \\
\hline $\begin{array}{l}\text { Información de } \\
\text { servicios } \\
\text { complementarios }\end{array}$ & $\begin{array}{ll}\text { - Alojamiento y alimentación } \\
\text { - Movilidad y renta de vehículos } \\
\text { - Agencias de viajes / Guías turísticos } \\
\text { - Servicios accesibles }\end{array}$ \\
\hline Seguridad & $\begin{array}{l}\text { - Contactos de oficinas de asistencia al turista en } \\
\text { caso de emergencia } \\
\text { - Contactos de servicios de quejas }\end{array}$ \\
\hline
\end{tabular}

Fuente: Altamirano \& Túñez, 2015

Algunos de los recursos para descargar que permiten complementar la experiencia del turista son:

- Mapas y folletos turísticos que contienen la información más relevante del lugar.

- Visitas guiadas a los principales atractivos que sirven para atraer la atención del turista.

- Realidad aumentada que permite vivir la experiencia antes de visitar el lugar. 
- Guías de viaje, indispensables para el proceso de planificación.

- Audio guías que complementan la experiencia durante el viaje.

- Juegos en línea que permiten interactuar con la oferta turística.

- Aplicaciones móviles y de geolocalización que adquieren relevancia en los últimos tiempos, por las facilidades que brindan al viajero, principalmente, durante el viaje.

La promoción digital debe mantener coherencia con la campaña turística, siendo necesario que los contenidos se adapten al formato de cada plataforma en la que se promocionan. Así como los medios de comunicación tradicionales tienen su propio formato, los digitales también requieren de una planificación estratégica específica y que los contenidos sean adecuados para cada uno, utilizando recursos multimedia que potencien la promoción turística.

"El nuevo entorno digital ha cambiado la forma de transmitir y recibir la información. El usuario es quien controla, domina, maneja y conecta los contenidos de una forma no lineal creando las denominadas obras abiertas a través de la participación y la interacción. Esta narración digital es posible gracias al hipertexto, a los recursos de multimedia e hipermedia, que permiten estructurar, interconectar e integrar la información" (Altamirano \& Túñez, 2014). Estos recursos multimedia (video, audio, hipertexto) fortalecen la promoción y difusión turística permitiendo, de cierto modo, tangibilizar la oferta para hacerla visible y real hacia el usuario.

"Los servicios turísticos son intangibles... como consecuencia de su intangibilidad ( $\mathrm{y}$ su inseparabilidad), los servicios no se pueden experimentar con los sentidos antes de su compra, a diferencia de un coche, por ejemplo. Ello implica que el grado de incertidumbre para el consumidor, antes de la adquisición de un servicio, sea generalmente mayor que con la compra de un bien tangible" (Serra; 2011: 61-62). Por esta razón, utilizar recursos multimedia permite tangibilizar la oferta turística y de esta forma se disminuye "la percepción de riesgos que el consumidor percibe como inherentes a la compra de este tipo de productos (riesgos que tienen que ver, sobre todo, con el hecho de que el servicio no existe hasta que se 
consume y con que debe ser pagado antes de ser consumido)" (Alonso, 2007).

\section{Interactividad y participación}

Las principales característica del turista 2.0 son la voluntad y el compromiso para interactuar en los entornos digitales. Por lo tanto, las plataformas de promoción turística deben brindar las condiciones necesarias para que se establezca una relación entre el usuario y la institución. También deben publicar contenido de calidad que motive al viajero a compartir la información en sus redes personales, hasta convertirlo en un promotor turístico que genere viralidad en la red, lo que beneficiará a la difusión de los mensajes promocionales.

Para contrarrestar la avalancha de información que existe en Internet las empresas y organizaciones turísticas deben constituirse como la principal fuente de información del viajero. En los sitios web se deben incluir las herramientas y los espacios para que los turistas reciban información directa y precisa desde la institución, ya sea a través de chats, solicitudes automáticas de información, servicios de atención en línea, videoconferencias o los datos de contacto de las oficinas de atención al cliente. Esto, con la finalidad de brindar una atención inmediata y oportuna.

En los sitios web también se debe potenciar la creación de comunidades virtuales en las que el viajero pueda compartir sus inquietudes y experiencias, motivando de esta forma al consumo del producto turístico. Desde siempre la referencia de otros clientes ha influido en la toma de decisiones, pero en la actualidad, el espacio digital adquiere relevancia. Como lo afirma Di Placido (2010, 7) "Mirando este nuevo escenario comunicativo desde una perspectiva comercial, podemos constatar como la interacción C2C -Consumer to Consumer- (Huang, Hsu, 2009) está teniendo un fuerte impacto sobre el entero proceso decisional en el sector turístico. El tradicional proceso comunicativo/informativo definido boca a boca se está transformando por efecto de los medios que operan en una lógica 2.0 en una tipología de boca a boca electrónico también definido e-Word of Mouth (Latvin, Golsmith, Pan, 2006), un proceso donde asume una relevante importancia el fenómeno de la influencia interpersonal 
online".

Las comunidades virtuales son una realidad. "Internet se está usando para practicar estrategias de marketing relacional y crear comunidades virtuales en torno a una marca o un producto en las que se busca la participación del visitante en el proceso de comunicación. Constituyen un verdadero punto de encuentro donde los usuarios con expectativas comunes comparten información sobre los productos que les interesan". (Túñez, Sixto \& Guevara, 2011: 53-65). Por lo tanto las empresas turísticas deben promover la creación de estas comunidades en torno a su producto turístico con la finalidad de obtener información directa de la fuente y para controlar lo que se dice respecto a su producto, lo que permitirá realizar mejoras y adaptar la oferta a las necesidades del mercado. En este sentido, los portales web turísticos también deben incluir herramientas interactivas como foros o encuestas y permitir la participación del usuario generando comentarios, información y compartiendo contenidos, entre otros.

La presencia de las empresas turísticas en las diferentes redes sociales también es fundamental para la promoción turística. Las redes generalistas, como Facebook, Google + y Twitter, permiten acercarse al público objetivo de una manera amigable y consiguen transmitir el mensaje, por principalmente generar viralidad. Mientras que las redes para compartir vídeo e imágenes, como YouTube, Pinterest, Flicker e Instagram, se convierten en un repositorio de material promocional turístico a la vez que divulgan las campañas publicitarias.

Es preciso recalcar que en este mundo globalizado no basta con crear las herramientas interactivas o tener presencia en las diversas redes sociales. Los organismos y empresas turísticas deben adquirir un compromiso 2.0. Producir contenido de calidad adaptado para cada plataforma, actualizar la información y atender de manera permanente e inmediata al usuario. Como recalcan Túñez y Sixto (2011), para "la participación en los entornos 2.0 no basta con la presencia, sino que se exige también la contribución activa tanto de los creadores como de los usuarios, intercambio opiniones y contenido, de manera que ambos obtengan beneficios, en plena sintonía con el concepto de marketing" 


\section{Aplicaciones móviles y de geolocalización}

En este mundo hiperconectado, no solo Internet y las redes sociales tienen un papel trascendental. En la actualidad, la posibilidad de conexión permanente que brindan los dispositivos móviles influyen en los cambios que se producen en la sociedad de la información, en la forma cómo las personas desarrollan sus actividades diarias, cómo se comunican, modificando hábitos de uso y consumo de los medios y promoviendo el acceso a la red de manera permanente.

Santiago Iglesias-Prada (2010) define a la movilidad como la capacidad de la red, el terminal y el usuario de acceder, conectar y mantener la sesión remota a un sistema de información corporativo con independencia de su ubicación, movimiento y contexto. En este sentido, Claudio Feijó realiza un análisis detallado de la influencia de las comunicaciones móviles en la Sociedad de la Información (2010: $5-8)$ :

Transformación de tiempo y espacio. Las comunicaciones móviles permiten estar conectados 24 horas todos y cada uno de los días del año y además hacerlo en o desde prácticamente cualquier lugar. Las sociedades modernas se expanden cada vez más en el tiempo y en el espacio. Este tiempo y espacio adquieren mayor relevancia, a la vez que los propios usuarios son capaces de utilizarlos más eficientemente en su provecho. En este sentido, hay que anotar que tanto los terminales móviles como los servicios asociados a ellos han evolucionado mucho más que sus equivalentes fijos, configurando un conjunto de utilidades muy apreciadas por los usuarios.

Siempre comunicados. Las comunicaciones móviles nos permiten tener un estilo de vida más 'personal' y al mismo tiempo nos permiten estar más conectados con nuestra red social, nuestros empleadores y nuestros colegas. Tanto la logística de las compañías como nuestra propia agenda de actividades laborales y sociales, sólo pueden ser manejadas de manera creciente con la ayuda de terminales móviles, agendas electrónicas, soluciones de mensajería instantánea, correo electrónico y redes sociales. En este punto es interesante 
notar, como otra de las transformaciones principales, que las comunicaciones en tiempo real facilitadas por las redes móviles no han sustituido a otros modos de comunicación, sino que más bien los han complementado.

Atracción por lo cercano. La globalización de la economía -el capital sobre todo- está evidentemente facilitada por las TIC. Sin embargo, las comunicaciones móviles nos ofrecen una perspectiva diferente del significado de la globalización. Por supuesto, las comunicaciones móviles nos permiten estar conectados con el resto del mundo y hacerlo allí donde nos encontremos. Sin embargo, y esto es evidente viendo las aplicaciones disponibles en las diversas app stores online para los terminales móviles, existe al mismo tiempo una especial atracción por el entorno local que circunda al usuario y que tiene un interés inmediato para él.

La personalización y su versión última, el individualismo, son también transformaciones que tienen mucho que ver con las comunicaciones móviles. Desde la sociología se considera a la individualización como uno de los rasgos más importantes de las sociedades del mundo desarrollado. Por supuesto, las comunicaciones móviles son las TIC que más contribuyen a este estilo de vida.

Relaciones sociales, más y más complejas. En particular, tal como se ha mencionado, las comunicaciones móviles han permitido mantener los lazos sociales a distancia y en cualquier momento. En una línea similar, también existe un creciente convencimiento entre los sociólogos de las comunicaciones de que éstas contribuyen a reforzar la cohesión social y a incrementar el llamado capital social en términos de la participación de los ciudadanos en los procesos sociales e institucionales

(Des)igualdad social. Por un lado, estas tecnologías sin duda contribuyen a difundir enormes cantidades de información de manera casi gratuita y, a partir de ella, ponen a disposición de todo el mundo una serie de conocimientos que antes eran de difícil acceso. Al mismo tiempo, parece evidente que el acceso a las tecnologías está relacionado con el nivel de educación y la posición en la sociedad. 
Quizá las comunicaciones móviles sean las TIC más democráticas a este respecto. Aun así, la llegada de la Banda Ancha móvil y la explosión de contenidos y aplicaciones que está teniendo lugar con ella puede contribuir a que suceda lo mismo que ha sucedido, por ejemplo, con el acceso a Internet.

Creación de contenidos. Varias características fundamentales de las comunicaciones móviles facilitan la participación de los usuarios: la interactividad, especialmente en comparación con los medios tradicionales como la prensa o la televisión; las posibilidades de expresión activa y creativa mediante las que los usuarios pueden transformarse cuando lo desean de consumidores pasivos en prosumers; la inmediatez, dada la continua y personal relación con el terminal móvil; y la compartición en red de una plataforma donde todos pueden crear colectivamente

Mayores oportunidades de elección. La última de las transformaciones sociales que está relacionada con las comunicaciones móviles y que quizá sirva de resumen de todas las anteriores es el incremento de oportunidades de elección en las actividades diarias. Las comunicaciones móviles permiten llevar una vida mucho más compleja y rica en elecciones personales.

En este sentido, el creciente uso de los dispositivos móviles es evidente, según International Telegraph Union (UTI) ${ }^{32}$ a finales de 2015, hay más de 7 mil millones de suscripciones celulares, correspondientes a una tasa de penetración del 97\%. Entre 2000 2015, la banda ancha móvil es el segmento de mercado más dinámico. A nivel mundial, la banda ancha móvil (mobilebroadband) alcanza una penetración del 47\% en el 2015, un valor que aumentó 12 veces desde 2007. La cobertura 3G llega al 69\%, cubriendo el $29 \%$ de las áreas rurales y el 89\% de las urbanas.

${ }^{32}$ La UIT es el organismo especializado de las Naciones Unidas para las Tecnologías de la Información y la Comunicación - TIC. 
En los últimos 30 años, el móvil se ha convertido en el ejemplo más popular y generalizado de tecnología personal en el planeta. En la actualidad hay 3.600 millones de suscriptores únicos y un total de 7.000 millones de conexiones móviles a nivel mundial (la diferencia se debe a que mucha gente posee más de una tarjeta SIM). La tecnología móvil ha tenido un profundo impacto en todos los aspectos de la vida, desde simplemente permitir que las personas se comuniquen entre sí, hasta facilitar el acceso a servicios de salud, educativos y financieros (Taverner, 2015, 58).

En el ámbito turístico, es evidente que el uso de dispositivos mejoran la experiencia del turista antes y durante el viaje, permitiendo de manera simultánea compartir las experiencias vividas. Un claro ejemplo del uso de la tecnología móvil en el turismo es el mundial de fútbol de Brasil, en el cual se batieron records de público enviando fotos a través de las redes móviles. Según Sinditelebrasil, durante los 64 partidos del mundial se realizaron 4.5 millones de llamadas, 48.5 millones de fotos y un total de 26.7 TB. Para esto fueron necesarias 4.738 nuevas antenas en los estadios que fueron compartidas entre las prestadoras (15.000 en total) y más de $10.000 \mathrm{~km}$ de fibra, sumando una inversión total que se estima en US $\$ 500$ millones, para satisfacer las necesidades de conexión de los espectadores (Cabello, 2015: 14).

A pesar de ser un hecho que las aplicaciones móviles y de geolocalización han tenido una gran acogida para el desarrollo de la actividad turística, no existen investigaciones científicas en esta área, y los estudios están ligados fundamentalmente a la educación, la economía y las finanzas.

Sin embargo, cada vez más las organizaciones y empresas turísticas optan por la creación de aplicaciones móviles y de geolocalización que permitan no solo promocionar sus productos y servicios, sino mejorar la experiencia del turista, añadiendo un valor a su oferta. En este contexto, en "M-tourism: las apps en el sector turístico", MartínSánchez et al. (2012) identifican 4 categorías de aplicaciones móviles que son utilizadas en el sector turístico. 
- Transporte: aplicaciones de sistemas de navegación GPS y de detección de radares junto a la información a tiempo real sobre el estado de los vuelos. Todo este tipo de herramientas pertenecen a los denominados servicios basados en la localización (localitation-based services). Los LBS son servicios individualizados para cada usuario en base a la información de su ubicación geográfica.

- Planificación y guías de viaje: Fundamentalmente en este apartado se encuentran las aplicaciones de buscadores de productos y servicios turísticos.

- Traductores: Que brindan el servicio de traducción instantánea a diferentes idiomas ya sea de texto o voz.

- Comunicaciones: Comunidades virtuales interactivas, la web social y también incluyen las aplicaciones de realidad aumentada.

\section{Conclusiones}

El turismo es una actividad dinámica que evoluciona y se adapta fácilmente a los cambios de la sociedad. De esta manera, la promoción y difusión de los destinos y/o productos turísticos no puede quedar relegada de estos cambios y debe estar a la vanguardia de las tecnologías de la comunicación y la información, para satisfacer las necesidades no solo de información del turista 2.0, sino a la vez permitir generar experiencias interactivas para conocer la oferta turística, a la vez que se generen los espacios que permitan participar de manera voluntaria y colaborativa como promotores turísticos, compartiendo, información, vivencias y referenciando los productos turísticos.

\section{Agradecimiento}

- La presente investigación se desarrolló en la Universidad Santiago de Compostela y Universidad Técnica Particular de Loja, con ayuda y aporte financiero de la Secretaría Nacional de Educación Superior, Ciencia, Tecnología e Innovación, SENESCYT, de Ecuador. 


\section{Referencias}

Alonso Hernández, C. (2007). "La construcción de la imagen turística de un territorio a través de la publicidad". En Questiones Publicitarias, Vol., 1.91 - 104. Recuperado en julio de 2015, de http://goo.gl/NCU3mi

Altamirano, V. \& Túñez, M. (2014). "Promoción y difusión turística en Iberoamérica. Análisis de contenidos y herramientas utilizadas en portales web y redes sociales". En Actas - VI Congreso Internacional Latina de Comunicación Social - VI CILCS - Tenerife: Universidad de La Laguna, diciembre 2014. Recuperado en julio de 2015, de http://goo.gl/RVc3pc.

Altamirano, V. \& Túñez, M. (2014). "Contenidos digitales para la promoción y difusión turística en Iberoamérica." En Contenidos innovadores en la universidad actual. España: McGraw-

Hill/Interamericana de España, S.L.

Antoni, S. (2013). Marketing turístico. Madrid, España: Ediciones Pirámide.

Cabello, S. (2015). "Opening new pathways to support enhanced collaboration". En Latin American visión. Annual magazine 2015, pág. 12 - 14. Recuperado en agosto 2015, de http://goo.gl/jAjMUa.

Caro, J., Luque, A. \& Zayas, B. (2014). “Aplicaciones tecnológicas para la promoción de los recursos turísticos culturales". En XVI Congreso Nacional de Tecnologías de la Información Geográfica. Alicante. Recuperado el 12 de julio de 2015, de http://goo.gl/2Svq6l.

Di Placido, A. (2010). "Interactividad usuario-usuario y redes sociales online en el sector turístico. Análisis de las páginas web turísticas oficiales de las administraciones andaluzas". En VIII Congreso Turismo y Tecnologías de la Información y las Comunicaciones Turitec 2010. Recuperado en julio de 2015, de http://goo.gl/naxoEF.

Feijo, C. (2010). “Comunicaciones móviles y sociedad”. En revista Telos, 84, pp. $18-29$.

Iglesias-Pradas, S. (2010). "Las TIC móviles. Medición del valor del negocio”. En revista Telos, 84, pp. 6 - 9.

Martín-Sánchez, M., Miguel-Dávila, J.A. \& López-Berzosa. (2012). "M-tourism: las apps en el sector turístico". En el IX Congreso 
Nacional "Turismo y Tecnologias de la Información y las Comunicaciones", Turitec 2012. Recuperado en julio 2015, http:/ / goo.gl/CcJJTz.

Observatorio Digital IAB Spain. (2012). Usos, actitudes y tendencias del consumidor digital en la compra y consumo de viajes. Recuperado el 10 de julio de 2015, de http:/ / goo.gl/hVZjfH.

Organización mundial de turismo. (2014). Recuperado en Febrero de 2015, de http://goo.gl/wmujVQ.

Ortega, E. \& Rodriguez, E. (2007). "La comunicación en los destinos turísticos. La percepción de los residentes en España”. En: El comportamiento de la empresa ante entornos dinámicos: XIX Congreso anual y XV Congreso Hispano Francés de AEDEM, Vol. 2, 2007 (Comunicaciones), pág. 22

Ortega, E. (2012) "Communication effects at tourism destinations. Proposed model. En: Gil, A.M. (Coord.), Creating new opportunities in an uncertain environment", XXVI Annual Congress of the European Academy of Management and Business Economics (AEDEM), Barcelona University, June 5,6 \& 7. Esic Editorial, Pozuelo de Alarcón, Madrid, pp. 1-13.

Palazón Meseguer, A. (2001). "Comunicación web: el valor de los contenidos en la Red". En revista Comunicar Vol., 17, 93 - 96. Recuperado en julio 2015, de http://goo.gl/GBwUpn.

Serra, A. (2013). Marketing turístico. Madrid: Ediciones Pirámide.

Taverner, D. (2015). "Digital inclusión in Latin America. En Latin American visión”. Annual magazine 2015, pp. 58 - 60. Recuperado en agosto 2015, de http://goo.gl/jAjMUa.

Túñez-López, M., Sixto, J., \& Guevara-Castillo, M. (2011). “Redes sociales y marketing viral: repercusión e incidencia en la construcción de la agenda mediática". Palabra Clave, 14 (I), 53 65. DOI: $10.5294 /$ pacla.2011.14.1.3

Túñez, M. y Sixto, J. (2011): "Redes sociales, política y compromiso 2.0: La comunicación de los diputados españoles en Facebook", en Revista Latina de Comunicación Social, 66. La Laguna (Tenerife): Universidad de La Laguna, páginas 210 a 246 recuperado el 15 de junio de 2015, de http://goo.gl/ltz8rv. DOI: 10.4185/RLCS-66-2011-930-210-246 



\section{A}

\section{Coordinadores}

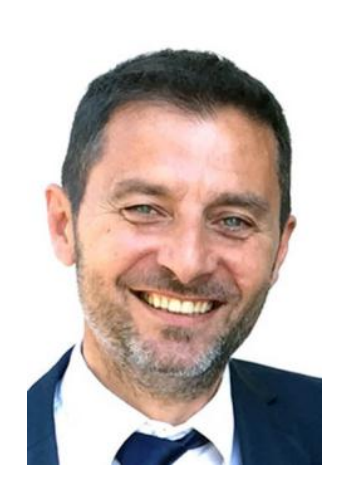

JosÉ Miguel TúÑEZ LóPEZ Universidad de Santiago de Compostela (España) miguel.tunez@usc.es

Doctor en Periodismo por la Universidad Autónoma de Barcelona, es Profesor de Comunicación organizacionaly de Estrategias y planes de comunicación en el Departamento de Ciencias de la Comunicación de la Universidad de Santiago de Compostela. Asesor y profesor de varias organizaciones y universidades europeas y latinoamericanas sobre procesos y planes de gestión de comunicación. Forma parte del Grupo de Investigación Novos Medios de la USC y, desde diciembre de 2007. Es autor de casi un centenar de informes, artículos y libros sobre comunicación. Ha sido Decano de la Facultad de Ciencias de la Comunicación de la USC (2004-2009). Es Premio Nacional de Periodismo Reina.

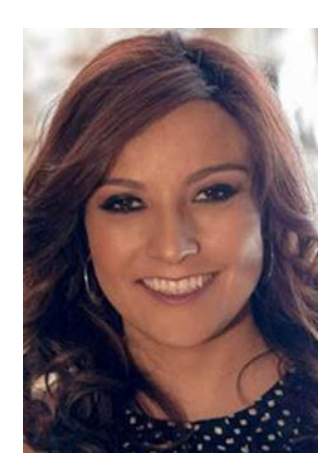

\section{VERÓNICA ALTAMIRANO}

Universidad Técnica Particular de Loja (Ecuador)

vpaltamirano@utpl.edu.ec

Máster en Comunicación e Industrias Creativas por la Universidad Santiago de Compostela (España), doctoranda de la USC, Diplomada en Comunicación

Organizacional, Diplomada en Comunicación para el Desarrollo y licenciada en Comunicación Social por la Universidad Técnica Particular de Loja (Ecuador). Docente principal de la Universidad Técnica Particular de Loja, miembro del Equipo de Calidad de la UTPL, coautora de libros internacionales, de artículos en revistas científicas, y divulgativas. Forma parte del grupo de investigación Comunicación Organizacional de la UTPL. 


\section{Autores}

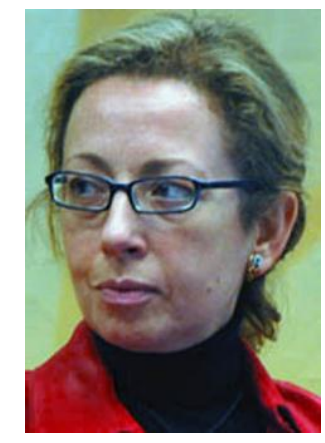

\section{MARÍA Yolanda MARTínez SOlana Universidad Complutense de Madrid}

mymartin@ucm.es

Doctora por la Universidad Complutense de Madrid, Licenciada en Periodismo, es Profesora Contratado Doctor del Departamento de Periodismo I de la Facultad de Ciencias de Información, desde 2008. Imparte asignaturas en el Grado de Periodismo y en diversos Máster oficiales, así como en el Máster de Periodismo de UCM-Abc.

Especialista en gestión de crisis de comunicación. Experta en comunicación institucional y de empresa; periodista y gestora de comunicación con amplia experiencia en el sector oficial. En el año 2000, nombrada Vocal Asesor del Ministerio de Sanidad y Consumo, desempeñando el cargo de Director de Comunicación.

Profesora invitada de diversas universidades iberoamericanas. Miembro de la Sociedad Española de Periodística, de la Federación de Asociaciones de la Prensa de España, de la Asociación de la Prensa de Madrid, de la Asociación de Periodistas Sanitarios y Jurado de los Premios de Periodismo y Responsabilidad Social Empresarial (FORÉTICA).

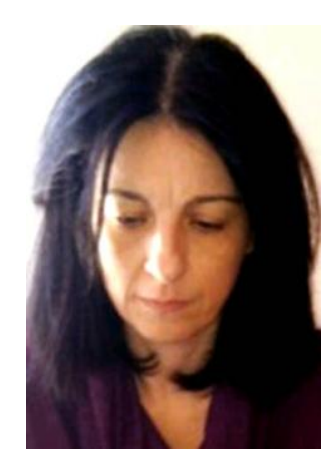

BARBARA MAZZA

Università degli studi di Roma, La Sapienza

(Italia)

barbara.mazza@uniroma1.it

Profesora adjunto de Comunicación para la Gestión Corporativa a la Universidad de Roma "La Sapienza". Es responsable científico, junto con Mario Morcellini, de Scienze.com - Observatorio sobre la formación universitaria en Comunicación, por la Conferencia Nacional de las licenciaturas universitarias de Ciencias de la Comunicación. Entre sus publicaciones en los últimos tres años, se segñalan: Il Progetto comunicazione alla sfida del mercato. Itinerari e prospettive dei laureati nel sud Europa (editado por Mario Morcellini, Franca Faccioli, Barbara 
Mazza, FrancoAngeli, Milano, 2014); Communication: anevergreento be renewed. Scienze.com reasearch Report 2012 (editado por, LuluPress, Raleigh, 2013); Paese che vai, comunicazione che trovi, (con Tunez López M., "Comunicazionepuntodoc", Lupetti, Milano, 2012); Dal micro al macro e ritorno. Percorsi e Strategie per lo Sviluppo locale (editado por, Homeless Book, Faenza, 2012).

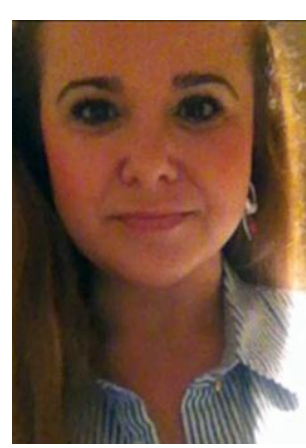

\section{BEGOÑA BUENO FERNÁNDEZ Universidad de Alicante (España) \\ bueno.begona@gmail.com}

Licenciada en Publicidad y Relaciones Públicas por la Universidad de Alicante (España) con Premio Extraordinario de Licenciatura. Master Oficial en Dirección de Protocolo, Producción, Organización y Diseño de Eventos por la Universidad Camilo José Cela, Madrid (España). Diplomada en CC. Empresariales por la Universidad Jaume I de Castellón (España). Por lo que respecta a su actividad investigadora, su trabajo fin de máster sobre Protocolo y Ceremonial Universitario obtuvo una calificación de Matrícula de Honor. Desde 2007 es personal de la Administración Pública. Prepara la tesis doctoral sobre protocolo y comunicación.

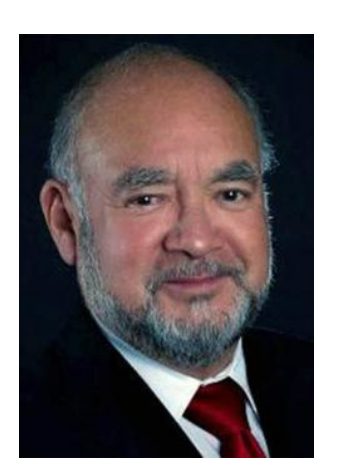

\section{MELITÓN GUEVARA CASTILLO} Universidad Autónoma de Tamaulipas (México) meligue@uat.edu.mx

Doctor en Comunicación y Periodismo por la Universidad de Santiago de Compostela (España), además de licenciado en Administración Pública y Master en Educación Superior, por la Universidad Autónoma de Tamaulipas (México). Es Profesor Emérito en la Universidad Autónoma de Tamaulipas (México). Imparte cursos a nivel licenciatura (Comunicación Política y Teoria de Investigación en Comunicación; en la Maestría de Comunicación (Modelos y procesos de la comunicación política) y en el Doctorado en Administración Pública (Comunicación Política). Su tesis doctoral fue: Información política y opinión pública en la prensa: Actores, polifonía y estrategias en la 
construcción del temario. Es líder del Cuerpo Academico Comunicación Política y Democracia, con las siguientes líneas de investigación: Comunicación política, opinión pública, calidad de la democracia, elecciones y medios de comunicación.

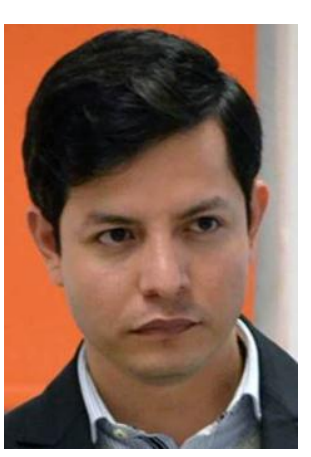

\section{Cruz Alberto Martínez Arcos}

Universidad Autónoma de Tamaulipas (México)

Doctor en Comunicación (2012) por Birkbeck College de la Universidad de Londres (Inglaterra), Master en Medios y Comunicaciones (2006) por Goldsmiths College de la Universidad de Londres, y Licenciado en Comunicación y Relaciones Públicas por la Universidad Autónoma de Tamaulipas (2004). Cruz Alberto Martínez-Arcos (Ciudad Victoria, Tamaulipas, 1980) es Profesor de Tiempo Completo en el área de Ciencias de la Comunicación de la Unidad Académica de Derecho y Ciencias Sociales de la Universidad Autónoma de Tamaulipas, desde enero de 2013. Imparte las asignaturas de Comunicación interpersonal, Comunicación no verbal, Metodología de la investigación y Seminario de investigación aplicada. En el nivel de maestría imparte Opinión Pública y Seminario de Tesis. Sus líneas de investigación actuales son análisis de políticas educativas, representaciones mediáticas de grupos vulnerables y del crimen organizado, así como medios de comunicación y democracia. Su tesis doctoral examina la evolución de la producción y la recepción de las representaciones televisivas de minorías sexuales en México.

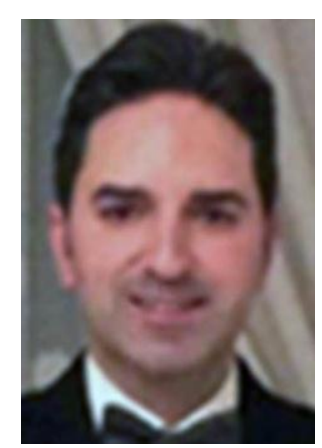

\section{JUAN LUIS GAMARRA SÁNCHEZ Universidad de Granada}

Licenciado en Derecho, Máster en Protocolo y Relaciones Institucionales. Responsable de Desarrollos de proyectos de la Junta de Andalucía. Profesor invitado de universidades españolas e internacionales. Socio fundador y secretario de 
Observatorio Iberoamericano de Investigación en Comunicación (OIDECOM).

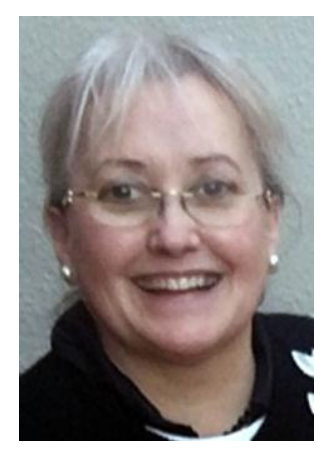

\section{MARTA GONZÁLEZ-PELÁEZ Universidad de Vigo (España)}

marconta@telefonica.net

Doctora en Comunicación, Licenciada en Publicidad y Relaciones Públicas, Licenciada en Comunicación, Diplomada en Turismo, Máster en Relaciones Públicas, Máster en Edición de libros y revistas, Especialista en Protocolo del Estado e Internacional, Postgrado en Responsabilidad Social Corporativa, Máster en Diseño, dirección de eventos. Profesora invitada en varias universidades españolas y extranjeras. Formadora empresarial internacional. Fundadora de su propia consultora de Comunicación y socia fundadora del Observatorio Iberoamericano de Investigación en Comunicación (OIDECOM).

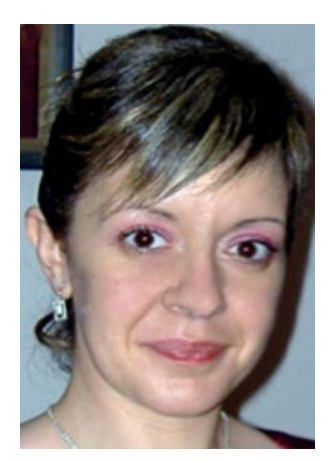

ANa MARía MaÑá ÁlVAREZ Universidad de Santiago de Compostela (España) Ana.Maria.Mana.Alvarez@sergas.es

Ana María Mañá Álvarez, Diplomada Universitaria en Enfermería; Máster en Atención Sanitaria, Gestión y Cuidados; Doctoranda del Programa de Doctorado en Atención Integral de la Salud de la Universidad de Santiago de Compostela (línea de investigación: Gestión de la Comunicación en las Organizaciones Sanitarias).

Labor asistencial de Enfermería en el área quirúrgica del Servicio Gallego de Salud desde el año 2000 (de 2000 a 2005 en Servicio de Quirófanos y desde 2005 a la actualidad en el Servicio de Cuidados Críticos y Recuperación Post-Anestésica del Hospital Clínico Universitario de Santiago de Compostela). Miembro de la Asociación Española de Enfermería en Anestesia, Reanimación y Terapia del Dolor. 


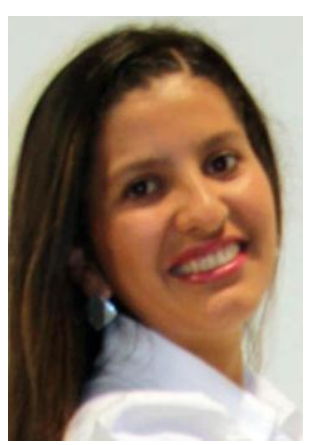

Cesibel Valdiviezo

Universidad Técnica Particular de Loja (Ecuador)

kcvaldiviezo@utpl.edu.ec

Doctoranda de la Universidad Santiago de Compostela (España). Máster en Investigación en Comunicación por la Universidad de Navarra (España). Además licenciada en Comunicación Social por la Universidad Técnica Particular de Loja (Ecuador). Actualmente es docente titular en el Departamento de Ciencias de la Comunicación de la Universidad Técnica Particular de Loja donde pertenece a la línea de investigación en Comunicación Organizacional. También es Coordinadora de Filosofía Corporativa y Responsabilidad Social Universitaria en la misma universidad. Es autora de varias investigaciones académicas, divulgativas y científicas. Ha impartido varias conferencias en eventos nacionales e internacionales como Argentina, Ecuador, entre otros

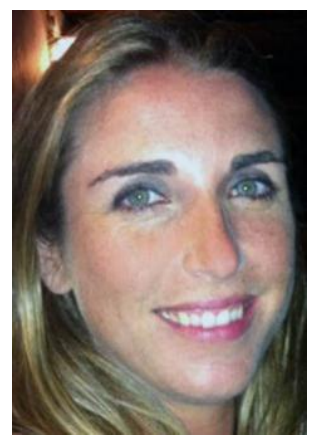

\section{Ma DOLORES GARCÍA FERNÁNDEZ} Universidad de Málaga (España) lolagarcia@uma.es

Doctora en Publicidad y Relaciones Públicas por la Universidad de Málaga (España), además de licenciada en Comunicación Audiovisual y Experta Universitaria en Comunicación, Protocolo y Organización de Actos Institucionales y Corporativos por la Universidad de Málaga (España).

Combina su actividad docente en la Universidad de Málaga con la profesional en el ámbito de las Relaciones Públicas concretamente en agencias de comunicación y distintos medios de comunicación de Málaga como ejecutiva de cuentas, planificadora y organizadora de eventos y relaciones públicas de numerosas entidades públicas y privadas. 
Ha recibido por estas cuestiones las menciones de Spin Off de la Universidad de Málaga en el año 1999, Futuránea 1999 de la Junta de Andalucía, Mejor empresa dirigida por Mujeres otorgado por el Excmo. Ayuntamiento de Málaga en el año 2004 y Mejor Empresa Joven por la Asociación de Jóvenes Empresarios en el año 2006. Colabora con varias Universidades de Londres, Paris y Polonia en el desarrollo del concepto de la Dirección Estratégica de las Relaciones Públicas en las Instituciones, donde ha impartido algunos seminarios y conferencias.

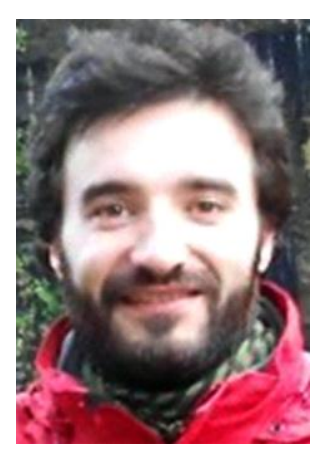

ENRIQUE MORALES CORRAL Associate Professor U-TAD UCJC (España) mors800@hotmail.com

Doctor en Ciencias de la Información por la Universidad Complutense de Madrid (España), además es Licenciado en Sociología por la Universidad Pública de Navarra (España). Es autor de más de una docena de artículos científicos, ha colaborado en siete libros académicos sobre comunicación y sociología y ha participado en más de veinte congresos académicos internacionales. Su tesis doctoral desarrolló un interesante estudio socio-económico sobre la industria cultural del videojuego, explicando su proceso ascendente en las últimas décadas como elemento de comunicación. Actualmente es miembro activo del grupo de investigación MDCS-UCM y profesor asociado en el centro U-TAD, centro adscrito a la Universidad Camilo José Cela, impartiendo diversas asignaturas de Sociología Digital.

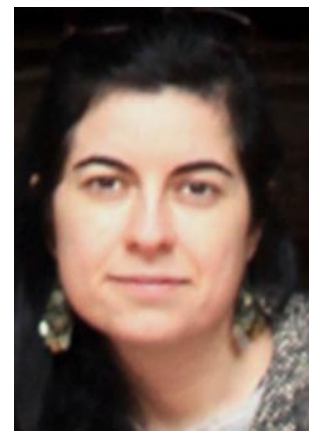

\section{CARMen Costa}

Universidade da Coruña (España)

carmencostasa@gmail.com

Doctora en Comunicación por la Facultad de Ciencias de la Comunicación de la Universidad de Santiago de Compostela, donde obtuvo el Premio Extraordinario de Doctorado. En la actualidad, es personal docente e investigador en la Universidade da Coruña, donde imparte la materia de 
Comunicación Corporativa. Ha recibido el Premio Drago de Revista Latina de Comunicación Social al segundo artículo más citado para el período 2008-2014. Es autora de numerosos trabajos de investigación en este ámbito como Comunicación Corporativa: Claves y escenarios (Ed. UOC, 2014) o La comunicación en el hospital. Estrategias de comunicación en el ámbito sanitario (Ed. Comunicación Social, 2011). Sus artículos de investigación sobre Comunicación en las Organizaciones son numerosos y han logrado impacto en revistas de reconocido prestigio nacional e internacional.

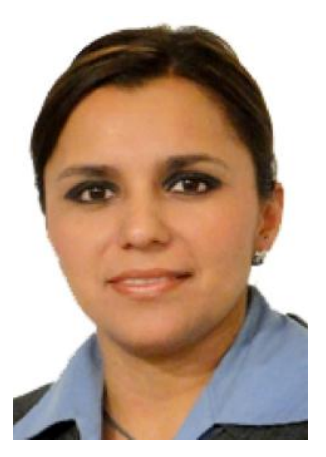

Karina Paola Valarezo González Universidad Técnica Particular de Loja, UTPL, Ecuador

kpvalarezo@utpl.edu.ec

En la actualidad es Directora de Comunicación, Dircom, de la Universidad Técnica Particular de Loja, UTPL. Es Licenciada en Relaciones Públicas por la Universidad Tecnológica Equinoccial, Quito, Ecuador. Doctora-PhD en Comunicación y Periodismo por la Universidad de Santiago de Compostela, España.

Ex asesora del Congreso de Diputados de la República del Ecuador en temas de comunicación. Profesora titular de grado y postgrado de las asignaturas de Relaciones Públicas, Gestión y Planificación de las Relaciones Públicas y Responsabilidad Social Empresarial. Investigadora.

Ha publicado artículos en revistas pertenecientes a índices como Latindex, Scopus e Isi web of knowledge; autora de capítulos de libros revisados por pares académicos; directora de proyectos de investigación; ponente en diferentes eventos académicos y de investigación.

Ex Coordinadora de la Titulación de Relaciones Públicas de la Universidad Técnica Particular de Loja, Modalidad Presencial, Ex Coordinadora de la Titulación de Asistencia Gerencial y Relaciones Públicas de la Universidad Técnica Particular de Loja, Modalidad Abierta y a Distancia. 
